

\title{
Holocene salt-marsh sedimentary infilling and relative sea-level changes in West Brittany (France) using foraminifera-based transfer functions
}

Pierre Stéphan, Jérôme Goslin, Y. Pailler, Rose Manceau, Serge S. Suanez, Brigitte van Vliet-Lanoë, Alain Hénaff, Christophe Delacourt

\section{To cite this version:}

Pierre Stéphan, Jérôme Goslin, Y. Pailler, Rose Manceau, Serge S. Suanez, et al.. Holocene salt-marsh sedimentary infilling and relative sea-level changes in West Brittany (France) using foraminifera-based transfer functions. Boreas, 2015, 44 (1), pp.153-177. 10.1111/bor.12092 . hal-01021995

\section{HAL Id: hal-01021995 https://hal.science/hal-01021995}

Submitted on 27 Oct 2014

HAL is a multi-disciplinary open access archive for the deposit and dissemination of scientific research documents, whether they are published or not. The documents may come from teaching and research institutions in France or abroad, or from public or private research centers.
L'archive ouverte pluridisciplinaire HAL, est destinée au dépôt et à la diffusion de documents scientifiques de niveau recherche, publiés ou non, émanant des établissements d'enseignement et de recherche français ou étrangers, des laboratoires publics ou privés. 


\section{BOREAS}

\section{Holocene salt-marsh sedimentary infilling and relative sea- level changes in West Brittany (France) using foraminifera- based transfer functions}

\begin{tabular}{|c|c|}
\hline Journal: & Boreas \\
\hline Manuscript ID: & BOR-093-2013.R3 \\
\hline Manuscript Type: & Original Article \\
\hline Date Submitted by the Author: & 14-Jun-2014 \\
\hline Complete List of Authors: & $\begin{array}{l}\text { Stéphan, Pierre; IUEM, CNRS, laboratory LETG-Brest-Géomer, UMR 6554, } \\
\text { Geography } \\
\text { Goslin, Jérôme; IUEM, CNRS, laboratory LETG-Brest-Géomer, UMR 6554, } \\
\text { Geography } \\
\text { Pailler, Yvan; INRAP-Bretagne, Archaeology } \\
\text { Manceau, Rose; CNRS, Laboratory LGP, UMR 8591, Physical Geography } \\
\text { Suanez, Serge; IUEM, CNRS, laboratory LETG-Brest-Géomer, UMR 6554, } \\
\text { Geography } \\
\text { Van Vliet-Lanoë, Brigitte; IUEM, CNRS, Laboratory Domaines Océaniques, } \\
\text { UMR 6538, Marine Geology } \\
\text { Henaff, Alain; IUEM, CNRS, laboratory LETG-Brest-Géomer, UMR 6554, } \\
\text { Geography } \\
\text { Delacourt, Christophe; IUEM, CNRS, Laboratory Domaines Océaniques, } \\
\text { UMR 6538, Marine Geology }\end{array}$ \\
\hline Keywords: & $\begin{array}{l}\text { Holocene, Sea-level change, France, Foraminifera, Transfer function, Salt- } \\
\text { marsh }\end{array}$ \\
\hline
\end{tabular}


1 Holocene salt-marsh sedimentary infilling and relative sea-level changes in West Brittany (France)

2 using foraminifera-based transfer functions

3

4

5

6

7

8

9

10

PIERRE STÉPHAN, JÉRÔME GOSLIN, YVAN PAILLER, ROSE MANCEAU, SERGE SUANEZ, BRIGITTE VAN VLIET-LANOË, ALAIN HÉNAFF AND CHRISTOPHE DELACOURT

Stéphan, P., Goslin, J., Pailler, Y., Manceau, R., Suanez, S., Van Vliet-Lanoë, B., Hénaff, A. \& Delacourt, C.: Holocene salt-marsh sedimentary infilling and relative sea-level changes in West Brittany (France) using foraminifera-based transfer functions. Boreas...

In order to reconstruct the former sea-levels and to better characterize the history of Holocene saltmarsh sedimentary infillings in West Brittany (western France), local foraminifera-based transfer functions were developed using Weighted-Average-Partial-Least-Squares (WA-PLS) regression, based on a modern dataset of 26 and 51 surface samples obtained from salt-marshes in both the bay of Tressseny and the bay of Brest. Fifty cores were retrieved from Tresseny, Porzguen, Troaon and Arun salt-marshes, which were litho- and biostratigraphically analyzed in order to reconstruct palaeoenvironmental changes. A total of $26 \mathrm{AMS}{ }^{14} \mathrm{C}$ age determinations were performed within the sediment successions. The Holocene evolution of salt-marsh environments can be subdivided into four stages: (1) a development of brackish to freshwater marshes (from c. 6400 to 4500 cal. a BP); (2) saltmarsh formation behind gravel barriers in the bay of Brest (from 4500 to 2900 cal. a BP); (3) saltmarsh erosion and rapid changes of infilling dynamics due to the destruction of coastal barriers by storm events (c. 2900-2700 cal. a BP); (4) renewed salt-marsh deposition and small environmental changes (from 2700 cal. a BP to present). From the application of transfer functions to fossil assemblages, 14 new sea-level index points were obtained indicating a mean relative sea-level rise around $0.90 \pm 0.12 \mathrm{~mm} \mathrm{a}^{-1}$ since 6300 cal. a BP. 
2 Pierre Stéphan (pierre.stephan@univ-brest.fr), Jérôme Goslin, Serge Suanez, Alain Hénaff, IUEM, 3 CNRS, laboratory LETG-Brest-Géomer, UMR 6554, France; Yvan Pailler, INRAP Bretagne, 4 laboratory Trajectoires, UMR 8215 \& laboratory LETG-Brest-Géomer, UMR 6554, France; Rose 5 Manceau, CNRS, Laboratory LGP, UMR 8591, France; Brigitte Van Vliet-Lanoë, Christophe 6 Delacourt, IUEM, CNRS, Laboratory Domaines Océaniques, UMR 6538, France; received 31st $7 \quad$ October 2013, accepted 19th June 2014.

During the last two decades, several reconstructions of late Holocene relative sea-level (RSL) change in the temperate zone have been developed using quantitative methodological approaches based on micro-fossil taxa such as foraminifera-based transfer functions (FBTFs). This statistical tool was widely used in the eastern north-Atlantic salt-marsh environments to produce high-resolution RSL reconstructions, notably along the coasts of UK (e.g. Edwards \& Horton 2000, 2006; Horton et al. 2000; Edwards 2001; Gehrels et al. 2001; Horton \& Edwards 2003, 2005; Boomer \& Horton 2006; Massey et al. 2006; Barlow et al. 2013) and in the Bay of Biscay (Leorri et al. 2008a, b, 2010, 2011; Rossi et al. 2011). The strong correlation of agglutinated salt-marsh foraminiferal assemblages with elevation was used in the transfer function approach to quantify the relationship between faunal data (relative abundance of species) and environmental data (tide levels) by regression analyses. The modern relationship was then applied to cores to reconstructed former tide levels from fossil assemblages.

Despite the high performence of this quantitative approach, only a limited number of FBTFs was attemped from salt-marsh sedimentary infillings along the French coasts of the Atlantic and the English Channel (Horton \& Edwards 2006; Leorri et al. 2008b, 2010; Rossi et al. 2011). In Brittany (western France), previous Holocene sea-level records are restricted to the Bay of Mont-Saint-Michel (marais de Dol) which are based on intercalated peat layers in the sediment succession (Van de Plassche 1991). On the north coast of Brittany, several peat deposits outcropping on the beaches of Saint-Marc and Brehec were studied by Ters (1986) and Delibrias et al. (1982). Similar deposits were 
1 used by Giot (1969) and Morzadec-Kerfourn (1969) for Holocene RSL reconstructions on the north-

2 west coast of Brittany. Recently, Goslin et al. (2013) provided some new data for the west Brittany 3 from basal peat contacts recognized on several beaches at low tide. Nevertheless, such basal peat 4 deposits only allow reconstruction of long-term RSL movements (Gehrels 1999) and are often absent 5 for the late Holocene period. This can lead to discontinuous and poorly defined RSL reconstructions 6 for the late Holocene period. In the south coast of Brittany, few sediment successions have been 7 studied by palynological analyses (Visset et al. 1995; Gaudin 2004; Visset \& Bernard 2006), yet no 8 attention was given to the RSL changes. Only Rossi et al. (2011) developed a FBTF to reconstruct 9 former RSLs for the last two centuries in the Morbihan Gulf.

10 Knowledge of coastal sedimentary infillings of Brittany is quite limited and has recently 11 undergone geological investigations. Yet, these were mainly concentrated on the foreshore of major 12 sedimentary coastal wedges, and on incised valley systems, delivering great information on the 13 postglacial transgression of Brittany for the early to mid-Holocene periods (Billeaud et al. 2007, 2009;

14 Sorrel et al. 2009, 2010; Tessier et al. 2010a, b). However, it must be noted that the stratigraphy of 15 small salt-marsh environments has been quite poorly documented until now (Morzadec-Kerfourn 16 1969; Stephan 2011a). In a recent synthesis of data collected since the beginning of the 2000s on the 17 French Atlantic coastal sediment wedges, Tessier et al. (2012) highlighted the strong control exerted 18 by rapid climatic changes on the infilling dynamics. Periods of enhanced storminess that occurred 19 during the Holocene were recognized within stratigraphies, and are responsible for significant 20 morphological changes of coastlines.

21 The aim of this paper is to examine the late Holocene sedimentary successions of four salt22 marshes of West Brittany, France, and to develop new and more accurate RSL reconstructions for the 23 area. To achieve these aims, we developed local FBTFs in both the bay of Tresseny and Brest on the 24 basis of the present-day distribution of foraminiferal-assemblages along cross-marsh transects. 25 Moreover, salt-marsh sedimentary infillings are described using litho- and biostratigraphical analyses. 26 Local FBTFs are applied to fossil foraminiferal-assemblages from vibracores to perform the 27 palaeoenvironmental reconstructions. The results are used to develop 17 new Sea-Level Index Points 28 (SLIPs) for West Brittany. 


\section{Regional setting and study areas}

3

4 Study areas are located on the northwest coast of Brittany (Fig. 1). This area is part of the Armorican

5 domain, located south-west of the English Channel, and was considered as a tectonically stable region

6 during the Holocene (Ters 1986; Morzadec-Kerfourn 1995). The major deformation seems to be the

7 result of the hydrostatic loading of the Channel platform during the Holocene transgression. A

8 subsidence of $1.5 \mathrm{~m}$ of the coast of Finistère is expected over the last 6000 years (Lambeck 1997).

9 Studied sites were selected because these areas present the thickest sediment successions with low

10 energy sediments (fine sand, silt and clay), dateable organic deposits and an open connection to the

11 sea.

Tresseny salt-marsh covers an area of 13 ha and is restricted to the inner part of a small 13 macrotidal narrow bay (Fig. 2) forming the mouth of the Quillimadec coastal river. This bay is located on the northwest coast of Brittany, characterized by sand-dominated sedimentary environments, composed of sandflats in the lower foreshore, sandy beaches in the middle-upper foreshore and coastal dune barriers and spits isolating brackish marshes. The coast is mainly exposed to North to NorthWest Atlantic swells. The tidal range reaches up to $7.2 \mathrm{~m}$ on spring tides and $3.45 \mathrm{~m}$ on neap tides (Table 1). The bay has a total surface of $130 \mathrm{ha}$, a length of $3.2 \mathrm{~km}$ and a width ranging from $200 \mathrm{~m}$ in the inner part and $500 \mathrm{~m}$ in the outer part. However, the bay is significantly narrower in its central part where the width does not exceed $75 \mathrm{~m}$, therefore sheltering the marsh from wave impact, especially its 21 northern part. Tresseny marsh is mainly covered with halophytic plants: Plantago maritima, Halimione portulacoides, Puccinellia Maritima, Juncus maritimus. In the 17th century, the inner part of the Tresseny bay was transformed into meadows by a drainage system after the construction of a 24 tide-mill.

The bay of Brest is approximately $11 \mathrm{~km}$ wide and $27 \mathrm{~km}$ long. The southern and northern 26 parts of the bay are mainly composed of gravel beaches and unconsolidated cliffs formed by 27 periglacial deposits; while the eastern part is composed of large mudflats and estuaries separated by 28 rocky headlands. The bay is a fetch-limited environment, where bigger storm-waves never exceed $1 \mathrm{~m}$ 
1 in height (Stéphan 2011b). The area is considered a macrotidal environment, with a tidal ranging from

$25.9 \mathrm{~m}$ on spring tides and $2.8 \mathrm{~m}$ on neap tides (Table 1). On the east coast of the bay of Brest, the 3 Lanveur marsh is located in the inner part of a large open bay sheltered by rocky headland. Vegetation 4 cover forms a $100 \mathrm{~m}$ wide zone in the inner part of the bay (Fig. 2) composed of halophytic plants as 5 Puccinellia maritima, Halimione portulacoides in the high marsh, and Spartina alterniflora in the low 6 marsh. A large mudflat characterized by hierarchical tide channels represents the outer part of the bay. 7 Others studied marshes in the bay of Brest (Porzguen, Troaon and Arun marshes) are back-barrier 8 environments. Coastal barriers are composed of mixed sand and gravel material and present a single 9 ridge affected by episodic overwash events (Stéphan 2011b, c). The marshes cover areas ranging from 103 ha for in both Porzguen and Arun salt-marshes and 6 ha for Troaon salt-marshes. The elevation of 11 the surface corresponds to the mean high-water spring-tide level. The superficial sediment cover is a 12 grey silty-clay mud (mean grain size between 20 and $40 \mu \mathrm{m}$ ). The bottom of tidal channel indicates 13 higher mean grain size values (around $300 \mu \mathrm{m}$ ). Marsh vegetation exhibits a vertical zonation and can 14 be sudivided into high marsh covered by Halimione portulacoides, Puccinellia Maritima, Plantago 15 maritima and middle marsh covered by Spartina alterniflora and Salicornia fragilis. The inner part of 16 the marsh is covered by brackish water vegetation consisting of Phragmites australis, Scirpus 17 maritimus and Juncus maritimus.

Material and methods

Transfer functions construction

Surface sediment sampling strategy was based on cross-marsh transects, covering tidal flat (or 24 channel) to brackish marsh, in order to cover different marsh subenvironments in terms of elevation 25 relative to tidal levels. The top $10 \mathrm{~cm}$ of sediment was sampled, considering that infaunal populations 26 of agglutinated foraminifera living at depths of up to $10 \mathrm{~cm}$ have been reported from salt-marshes in 27 the French Atlantic coast (Duchemin et al. 2005) and also in the mid-Atlantic and southeastern USA 28 (Goldstein et al. 1995; Saffert \& Thomas 1998; Hippensteel et al. 2000). Consequently, a vertical 
1 error of $\pm 0.10 \mathrm{~m}$ was added to the palaeomarsh reconstructions performed by using transfert function 2 models.

3 Topographic elevation was measured for all modern samples relative to the French ordonance 4 datum (NGF) using a Trimble 5700/5800 Differential GPS. The total elevation error related to DGPS 5 measurement $( \pm 0.02 \mathrm{~m})$ and geodesic marker precision $( \pm 0.1 \mathrm{~m})$ is estimated to $\pm 0.12 \mathrm{~m}$ (Suanez et al. 6 2008). Topographic elevations were converted to tide levels using measurements performed by the 7 SHOM (Service hydrographique et Océanographique de la Marine). The margin of error related to the 8 datum conversion was less than $\pm 0.001 \mathrm{~m}$. Modern samples were sieved through a $500 \mu \mathrm{m}$ and $63 \mu \mathrm{m}$ mesh and washed to remove clay and silt material. The residual fraction was split into 3 subsamples $(<100 \mu \mathrm{m}, 100-200 \mu \mathrm{m},>200 \mu \mathrm{m})$.

11 Where possible, a minimum amount of 100 specimens of foraminifera (dead and alive) were counted 12 for each subsample using a stereoscopic binocular microscope. Species identification was mainly 13 based on specific papers showing modern assemblages and their distribution patterns in the French 14 Atlantic salt-marshes (Moulinier 1996; Redois \& Debenay 1996; Goubert 1997; Armynot du Châtelet 15 et al. 2005; Duchemin et al. 2005; Debenay et al. 2006; Leorri et al. 2010; Rossi et al. 2011). 16 Ammonia and Elphidium were recorded as generic groups (Hayward et al. 2004; Horton \& Edwards 17 2006; Kemp et al. 2012).

18 A detrended canonical correspondance analysis (DCCA) was employed to determine if taxon19 environment response was unimodal (Gaussian) or linear (Sejrup et al. 2004) using CANOCO 4.0 (Ter 20 Braak \& Smilauer 1998) software. Furthermore, the programme C2 (version 1.4, Juggins 2004) was 21 used to construct the transfer functions. The performance of the transfer functions was assessed by 22 calculating root mean squared error of prediction (RMSEP), maximum bias, and the correlation of 23 observed versus predicted values $\left(\mathrm{r}^{2}\right)$. Data was jacknifed to assess the overall predictive abilities of 24 the training set. 
1 The lithostratigraphy of sediment infilling was investigated via a series of 50 auger cores (Fig. 2). A

2 set of vibracores were also collected (called "reference cores" in the paper) and separated into sections 3 in the laboratory for AMS ${ }^{14} \mathrm{C}$ dating, sedimentological and foraminiferal analysis. The ground surface 4 elevation was obtained for all cores by DGPS mesurements. Possible sources of altitudinal error have 5 been considered in detail by Shennan (1986). Overall altitudinal error was evaluated to $\pm 0.14 \mathrm{~m}$, 6 accounting for (i) a potential $\pm 0.02 \mathrm{~m}$ incertitude in the measurement of the stratigraphic position of 7 the sample and (ii) a $\pm 0.12 \mathrm{~m}$ uncertainty due to levelling to the benchmark. Grain size analysis was 8 conducted after a destruction of organic material using a laser analyzer (type Malvern Mastersizer $92000)$ for fine fraction $(<1 \mathrm{~mm})$ and by sieving procedure for coarse material $(>1 \mathrm{~mm}) .26$ carbon-rich 10 sediment samples were collected from reference cores and dated by radiocarbon, providing a reliable 11 chronological framework of the salt-marshes sedimentary infillings (Table 2). The conventional 12 radiocarbon dates were calibrated using software Calib 7.0 (Stuiver \& Reimer 1993) and the IntCal13 13 calibration curve (Reimer et al. 2013). Errors in the inferred radiocarbon dates cannot be excluded 14 because of the possible contamination of the sediment by older or younger carbon, such as by rootlet 15 penetration or inwashed material. Nevertheless, most of radiocarbon measurements were carried out 16 on detritial fragments of in situ halophitic plants selected under binocular microscope. Indeed, as 17 pinpointed by several authors (Gehrels et al. 1996; Törnqvist et al. 1998; Gehrels 1999) the fragility of 18 plants remains largely reduces their potential of re-deposition and the latter can thus be considered as 19 reflecting the depositional environment of the dated sediment.

\section{Results}

\section{Contemporary foraminireral distribution}

25 Along Tresseny salt-marsh transect, 26 samples containing 14 species of foraminifera with an 26 abundance of at least $2 \%$ in a single sample were collected between MHWNT and MHWST (Table 27 S1). Fig. 3 exhibits the main foraminiferal species of the total (live and dead) training set plotted 28 against the elevation. Only one sample contained less than 200 individuals. Hyaline and porcelanous 
1 species were present only in samples collected in the tidal creek below $2.75 \mathrm{~m}$ NGF. Calcareous

2 foraminiferal assemblages are dominated by Haynesina germanica (mean value and range: $44 \%, 0$ $373 \%$ ) followed by Elphidium sp. (9\%, 0-29\%) and Ammonia sp. (8\%, 0-18\%). Species diversity 4 decreases with increasing elevation along the transect. Agglutinated species dominate the assemblages 5 in the upper part of the marsh. Jadammina macrescens (38\%, 16-64\%) and Miliammina fusca (34\%, $6 \quad 16-52 \%)$, together with Haplophragmoides wilberti $(25 \%, 15-42 \%)$ were the most abundant species 7 between $2.75 \mathrm{~m} \mathrm{NGF}$ and $3.62 \mathrm{~m} \mathrm{NGF}$.

At Lanveur, 23 samples were collected between the MTL and the MHWST (Fig. 3). Ten 9 species of foraminifera (abundance $\geq 2 \%$ in a single sample) were identified (Table S1). Three main 10 zones can be distinguished along the transect from foraminiferal assemblages corresponding to the 11 mud-flat, the low salt-marsh and the high salt-marsh, respectively (Fig. 3). Calcareous species 12 dominate the transect's lowest zone from $0.5 \mathrm{~m} \mathrm{NGF}$ to $1 \mathrm{~m} \mathrm{NGF}$. Foraminifera in the mud-flat zone 13 are dominated by $H$. germanica (44\%, 22-65\%), Ammonia sp. (41\%, 31-57\%) and Elphidium sp. (7\%, $2-13 \%)$. The most abundant species found on the low salt-marsh zone was $M$. fusca $(60 \%, 30-81 \%)$ at 15 an elevation ranging from $1 \mathrm{~m}$ to $2 \mathrm{~m} \mathrm{NGF.} J$. macrescens $(41 \%, 29-63 \%)$ dominates the high saltmarsh zone between $2 \mathrm{~m} \mathrm{NGF}$ and $3.2 \mathrm{~m} \mathrm{NGF}$.

Along the Arun cross-marsh transect, a total of 30 samples were collected between the MHWNT and the HAT (Fig. 3). Foraminiferal assemblages present a low species diversity with only 5 agglutinated species of foraminifera with an abundance of at least $2 \%$ in a single sample identified.

20 The most abundant species were Trochammina inflata $(31 \%, 11-57 \%)$ and $J$. macrescens $(27 \%, 5$ $2169 \%)$, together with M. fusca (21\%, 3-61\%) and H. wilberti (20, 2-52\%). Two upland samples fringing 22 the salt-marsh contained no foraminifera (E29 and E30, Fig. 3).

Foraminifera-based transfer functions development

In the bay of Brest, we developed transfer functions to reconstruct palaeomarsh elevation for fossil 27 samples using three models (Table 3). The first 'all data' model used the full modern dataset obtained 28 from the two cross-marshes transects located in the Bay of Brest. The training set consisted of 51 
1 modern surface samples and 14 species of foraminifera, covering an elevation range of $3.27 \mathrm{~m}$. DCCA

2 indicated that the modern species-environmental response was unimodal with a gradient length of

32.515 allowing us to apply WAPLS regression method. The model does not successfully predict the

4 elevation of samples. The transfer function performance estimated a high RMSEP of $\pm 0.48 \mathrm{~m}$ and a

5 low $\mathrm{r}^{2}$ at the 2 nd component (Table 3). This suggests that the predictive abilities and the relationship

6 between observed and predicted values are poor and therefore induce high associated errors (Fig. 4).

7 When a large training set spans a long elevation range, some samples may present a weak relationship

8 with elevation because of the possible influence of other environmental factors, taphonomic processes

9 or natural variability in species response to their controlling variable (Edwards \& Horton

10 2000; Edwards 2001; Woodroffe \& Long 2009; Barlow et al. 2013). Consequently, some authors

11 remove surface samples collected in tidal flats and low salt-marshes which often show non-linearity

12 with elevation. This procedure aims to increase the transfer function's predictive ability (Edwards \&

13 Horton 2000; Hamilton \& Shennan 2005). In the 'all data' model, mudflat samples are derived from

14 Lanveur cross-marsh transect (Fig. 4) where a sharp transition is observed between the unvegetated

15 mudflat zone dominated by calcareous taxa and the vegetated saltmarsh zone dominated by

16 agglutinated species (Fig. 3). The samples from these two different foraminiferal zones are clearly

17 separated in the plot of observed versus predicted elevation, which illustrates the difficulty to combine

18 both in the same regression model. However, samples collected in the salt-marsh zone seem to be in

19 alignment according to the elevation range. Therefore, a second 'salt-marsh' model was developed

20 after excluding samples from mudflat environment. This reduced the training set to 43 samples and 9

21 taxa. The elevation range was shortened to $2.58 \mathrm{~m}$.

22 The 'salt marsh' model in comparison with the 'all data' model failed to produce a better 23 performance (Table 3) on account of the large number of samples with high residual values. Two 24 outliers were represented by samples L10 and L19 collected along the Lanveur cross-marsh transect 25 which exhibited an unusually high abundance of Ammonia sp. and Elphidium sp. compared to other 26 neighbouring samples (Fig. 4). Furthermore, 10 samples collected both in the salt-pans and tidal 27 creeks of the Arun salt-marsh seemed to have a poorly defined relationship to elevation. This likely 28 suggested the influence of other environmental factors within these microforms. The salt-pans and 
1 tidal-creeks are characterized by the absence of a vegetation cover and probably by large variations of 2 temperature and salinity that may disturb locally the general pattern of the foraminiferal zonation.

3 These samples were removed from the training set to develop a third 'pruned' salt-marsh model using 4 WAPLS regression method. This model consists of 29 modern surface samples, 8 foraminifera taxa 5 and cover an elevation range of $2.35 \mathrm{~m}$. The transfer function performance estimates a RMSEP of $6 \pm 0.20 \mathrm{~m}$ and $\mathrm{a} \mathrm{r}^{2}$ of 0.94 at the component 3 (Table 3). This suggests that the predictive abilities and 7 the relationship between observed and predicted values were significantly improved. However, a part 8 of this performance improvement can be considered as artificial. By excluding samples from the 9 training set, we reduced the size of the modern dataset and we made the choice not to capture the 10 entire diversity of the sampled modern environments. This approach has automatically lead to a better 11 performance of models, but it limits their ability to reconstruct all the past environments.

12 For the Tresseny salt-marsh, we developed a model ('Tresseny model') using the entire 13 training set collected along the cross-marsh transects. This model included all modern samples 14 collected and all species and constist of 26 modern surface samples, 14 foraminifera taxa, covering an 15 elevation range of $1.61 \mathrm{~m}$. DCCA suggests that unimodal methods of regression and calibration were 16 appropriate because the gradient lengths were greater than 2. The Weighted Averaging-Partial Least 17 Squares method was used to produce a model with a RMSEP of $\pm 0.14 \mathrm{~m}$ and a $\mathrm{r}^{2}$ of 0.90 at the 2 nd 18 WAPLS component. The fit between observed and predicted elevation is good, albeit there are some 19 non-linearities by places along the elevation range (Fig. 5). Samples collected on the unvegetated 20 surface of the tidal creek show a poor statistical relationship with elevation. This is probably due to the 21 influence of other environmental factors or taphonomic processes (Edwards \& Horton 2000) 22 previously described.

Salt-marshes sedimentary infilling: lithostratigraphy, biostratigraphy

26 Based on sedimentological analyses (grain size analysis, sedimentary structures, organic and 27 foraminiferal contents), the investigated Holocene sediment successions were subdivided into 9 28 lithofacies (LF1 to LF10, Table 4). Their interpretation in terms of depositional environments were 
1 based on classic models (Reineck \& Singh 1980; Allen 2000, 2003), regional studies of estuarine and

2 coastal areas (Billeaud et al. 2007, 2009; Lespez et al. 2010; Stéphan 2011a, b; Tessier et al. 2012;

3 Goslin 2014), and comparison with modern sediments that characterize coastal environments in NW

4 Brittany (Hallégouët 1971; Guilcher et al. 1990) and the bay of Brest (Stéphan 2011a).

5

At Porzguen, a basal peat unit (LF1) overlays a weathered shale pre-Holocene surface (Fig. 6).

The age of this unit is dated to 5605-5324 cal. a BP at the base and 5036-4625 cal. a BP at the top. Benthic foraminifera assemblages are dominated by $T$. inflata (average 35\%), J. macrescens (average $30 \%$ ) and $H$. wilberti (average 30\%, Table S2). This assemblage is indicative of high marsh environment. The basal peat unit is overlaid by an organic silty clay unit (LF2) found from -0.65 to $+1.1 \mathrm{~m} \mathrm{NGF}$ in core P-C2. The contact between the basal peat and this overlaying unit is gradational and reflects an increase of the marine influence in a salt-marsh environment probably sheltered by a coastal barrier. From +1.1 to $+3 \mathrm{~m} \mathrm{NGF}$, this unit is replaced by a grey silty-clay (LF4) characterized by two $20 \mathrm{~cm}$ thick layers with milimetric laminations of black organic-rich silt found at a depth between $+1.4 \mathrm{~m} \mathrm{NGF}$ and $+2.2 \mathrm{~m}$ NGF. This unit presents foraminiferal populations highly dominated by T. inflata (Fig. 7A). However, the laminated layers show no foraminifera and may have accumulated under low salinity conditions, in a back-barrier freshwater pond during phases of saltmarsh closure by the gravel barrier. At Porzguen, the top unit of the sedimentary succession at Porzguen corresponds to LF2. Fossil foraminiferal assemblages are dominated by $T$. inflata (average $60 \%$ ) and $J$. macresens (average $30 \%$ ).

At Troaon, the holocene sediment inflilling is $5.5 \mathrm{~m}$ thick (Fig. 6). The base of the succession consists of reed peat layer containing phragmites macro-remains (LF1) and agglutinated foraminiferal populations dominated by $T$. inflata, J. macrescens and $H$. wilberti indicative of high marsh environment (Table S3). The timing of the peat deposition is between 6399-6015 and 4956-4569 cal. a BP. This deposit was found at a depth between $-2.8 \mathrm{~m} \mathrm{NGF}$ and $-0.65 \mathrm{~m}$ NGF, which probably extends seaward and is overlaid by the gravel barrier and beach. Overlaying the peat is a silty clay sediment with salt-marsh plant fragments and rootlets (LF2) found from -2 m NGF to the present-day surface. It forms a gradual transition into the underlying basal peat unit. Benthic foraminifera assemblages are dominated by $J$. macrescens and T. inflata in relatively equal proportion (about 45\%) indicative of 
1 high marsh environment (Fig. 7B). Two $10 \mathrm{~cm}$ thick layers of silty-sand horizons (LF3) were found

2 between +0.1 and $+0.7 \mathrm{~m} \mathrm{NGF}$ in cores T-C1 and T-C2. The contact between these horizons and the 3 clay unit is very sharp, which indicates erosion. These horizons are characterized by numerous shell

4 fragments and the significant presence of hyaline species as $H$. germanica and Elphidium sp. 5 indicative of a low marsh environment.

At Arun, the Holocene succession is composed of two main lithofacies (LF2 and LF3), 7 characterized by interbedded coarse deposits (LF5) in the seaward cores which are associated with 8 several phases of gravel barrier construction and breakdown (Fig. 6). A silty sand unit forms the base 9 of the sequence. This unit is found between -0.2 and $+0.7 \mathrm{~m} \mathrm{NGF}$ in the seaward cores A-C10 (Fig. 10 7C). Associated with abundant organic detrital remains, foraminifera assemblages are dominated by $J$. 11 macrescens (average 55\%) and T. inflata (average 40\%, Tables S4, S5) indicating a high-marsh 12 environment (Fig. 7D). We interpret the presence of $M$. fusca and some calcareous species, in 13 association with shell fragments, as the expression of an open-bay environment where waves convey 14 material from the low-marsh to foreshore domains. Two dates indicated that this unit was formed 15 between 2941-2748 and 2691-2159 cal. a BP. From +0.7 m NGF to the present-day surface, a silty 16 clay unit is $2.9 \mathrm{~m}$ thick formed from $2690-2160$ cal. a BP. Foraminifera assemblages are dominated by $17 J$. macrescens (average 48\%) and T. inflata (average 45\%) indicative of a high-marsh environment. In core A-C10, an interbedded coarse sand and gravel deposit corresponding to LF5 is found at an elevation between 1.7 and $2.5 \mathrm{~m} \mathrm{NGF} \mathrm{(Fig.} \mathrm{7C).} \mathrm{This} \mathrm{deposit} \mathrm{may} \mathrm{correspond} \mathrm{to} \mathrm{a} \mathrm{second} \mathrm{overwash}$ covering a weathered granite substrate on a mean thickness of 1 to $1.5 \mathrm{~m}$ (Figs 8, 9). The significant proportion of sand and the absence of foraminifera seems to indicate a back dune brackish marsh. A series of dates from core G-C2 indicate this basal peat was formed from 6403-6299 cal. a BP in this 25 core. The age of the upper part of the basal peat range from $4826-4572$ cal. a BP. A coarse sand unit 26 (LF7) overlies the basal peat at a depth of $-2.2 \mathrm{~m} \mathrm{NGF}$ up to the most landward cores at a depth of +1 $27 \mathrm{~m}$ NGF, with a thickness gradually decreasing to $0.10 \mathrm{~m}$ at core G-C5. The sharp transition between 28 LF6 and LF7 suggests a rapid change toward high hydrodynamic conditions. The age of this 
1 environmental change is known by a series of 5 radiocarbon dates obtained on the minerogenic sandy-

2 silt unit (LF8) overlying the coarse sand layer. The ages cover a short period around 2850-2700 cal. a

3 BP and suggest high rates of sedimentation (around $12 \mathrm{~mm} \mathrm{a}^{-1}$ ). Foraminiferal analysis from core G-

4 C2 indicates low density of specimens, probably reworked and composed by agglutinated species such

5 as J. macrescens, H. wiberti, T. inflata and M. fusca. The scarcity of foraminifera is probably due to a

6 dilution of specimens related to the high rates of sedimentation. Associated with the low density of

7 detrital plant fragments, this suggests a sand-flat environment subjected to relatively high

8 hydrodynamic conditions and high sediment supply (Goslin et al. 2013). The upper part of the

9 succession is formed by an organic-rich fine sand unit (LF9) within the seaward cores and reed peat

10 (LF6) in the landward cores. This unit is found from $+2.8 \mathrm{~m}$ NGF to the present-day surface.

11 Foraminifera assemblages are dominated by $J$. macrescens (average 55\%), H. wiberti (average 22\%)

12 and M. fusca (average 16\%) (Fig. 9, Table S6). It reflects a gradual change from a sand flat to a salt13 marsh between $1825-1631$ and 527-338 cal. a BP.

\section{Discussion}

At Tresseny, the palaeomarsh elevation reconstructions are based on the application of the 'Tresseny 20 Model' with a low RMSEP value $( \pm 0.14 \mathrm{~m})$. In the bay of Brest, the 'pruned' salt-marsh model was 21 prefered because it presents the lowest RMSEP values $( \pm 0.20 \mathrm{~m})$ compared to other developed models 22 for this area (Table 3). The levels of precision are comparable to those found within the same tidal 23 range around the northeast Atlantic coasts (Horton \& Edwards 2006; Gehrels et al. 2001; Massey et al. 24 2006; Leorri et al. 2008a, b, 2011). In Brittany, Rossi et al. (2011) developed a model with a lower 25 RMSEP value of $\pm 0.10 \mathrm{~m}$ within the mesotidal setting of the Morbihan Gulf (tidal range $c .3 \mathrm{~m}$ at 26 spring tide). 
1 (MAT) (Birks 1995). The 20th percentile of the dissimilarity coefficients calculated between all

2 modern samples was used as the cut-off between 'close' and 'poor' modern analogues for fossil

3 samples. The 5th percentile was the threshold for defining 'good' modern analogues (Barlow et al.

4 2013; Watcham et al. 2013).

5 At Tresseny, foraminiferal occurence is only significant at $95 \mathrm{~cm}$ depth. The assemblages are

6 dominated by J. macrescens (average 55\%), H. wiberti (average 22\%) and M. fusca (average 16\%).

7 The palaeoelevations of the marsh provided by the transfer function reconstructions are around the

8 MHWST level, ranging from $+3.5 \mathrm{~m}$ to $+3.95 \mathrm{~m}$ NGF (Fig. 9, Table S6). With the exception of one

9 fossil sample, the MAT identifies a majority of 'good' and 'close' analogues therefore indicating these

10 results to be reliable. The much higher abundance of the foraminiferal populations associated with the

11 increase of the organic content in the upper part of the sediment core seems to reflect a gradual change

12 from a sand flat to a salt-marsh between 1820-1690 cal. a BP and the present-day (accretion rate 13 around $\left.0.6 \mathrm{~mm} \mathrm{a}^{-1}\right)$.

14 At Porzguen, the transfer function reconstructions indicate a palaeomarsh surface elevation 15 between +3 and $+4 \mathrm{~m} \mathrm{NGF}$ (Fig. 7A, Table S2) corresponding to a high salt-marsh environment. A 16 significant number of fossil samples have 'poor' modern analogues, especially in the upper part of the 17 sediment succession corresponding to LSU4. Based on lithostratigraphical analysis, this deposit is 18 interpreted as a brackish marsh episodically transformed into a freshwater swamp occupying a back19 barrier pond. A possible explanation of the 'unreliable' results obtained by FBTF is the absence of 20 samples corresponding to this particular depositional environment in our modern training set. In this 21 case, the model does not provide a good approximation of past environments. Furthermore, fossil 22 samples with 'poor' analogues are characterized by a very high proportion of $T$. inflata within 23 assemblages (Fig. 7A). The high representation of this robust species may result from a preferential 24 enrichment of the fossil assemblages due to taphonomic processes affecting the other species and 25 biassing the interpretations (Alve \& Murray 1994; Goldstein \& Watkins 1999; Patterson et al. 1999; 26 Horton \& Edwards 2006).

27 A similar interpretation could explain the few 'close' analogues within the basal peat unit 28 (LF1) at Troaon (Fig. 7B, Table S3). The FBTF reconstruction based on 'close' analogues suggests a 
1 palaeomarsh elevation between +3.26 and $+3.67 \mathrm{~m} \mathrm{NGF}$ for this deposit. Within the two silty-sand 2 layers corresponding to LF3, quantitative reconstructions indicate major changes of palaeomarsh 3 elevations. Despite 'poor' modern analogues of fossil samples, the estimations provided by the pruned 4 'salt-marsh' model are of -0.82 and -0.49 m NGF for both the lower and upper horizon, respectively.

5 These elevations correspond to tide levels ranging from the MLWNT to the MT. These layers are 6 associated with erosional contacts and probably reflect sediment inputs from the foreshore during an 7 opening period of salt-marsh environment caused by coastal barrier breakdown. The upper part of the 8 sediment succession (LF6) shows reconstructed palaeosurface elevations between +2.81 and $+3.74 \mathrm{~m}$ 9 NGF indicative of an accretionary environment under a RSL rise trend.

10 At Arun, the reconstructed palaeomarsh elevation is between +2.39 and $+3.54 \mathrm{~m}$ NGF (Tables 11 S4, S5) corresponding to tide levels between the MHWNT and the MHWST (Figs 9, 10). The number 12 of 'poor' fossil analogues is significant within core A-C14, resulting from high proportion of T. inflata 13 in foraminiferal assemblages, probably reflecting brackish marsh conditions during closure of salt14 marsh. Throughout the cores A-C10 and A-C14, the low amplitude fluctuations in the reconstructions 15 may be related to the gravel barrier evolution (episodic breaching or overwash), leading to temporary 16 changes in the hydrodynamic conditions (wave and tide), vegetation cover and foraminiferal zonation 17 in the protected back-barrier setting.

In this section we initially convert the results of FBTFs models into new RSL records for West Brittany (Table 2) and subsequently compare them with previously obtained similar data (Table 5), produced along the Brittany coastline (Morzadec-Kerfourn 1969; Van de Plassche 1991; Visset et al. 1995; Regnauld et al. 1996; Gaudin 2004; Visset \& Bernard 2006; Stéphan \& Laforge 2013; Goslin et al. 2013). The vertical position of the sea-level index point (SLIP) relative to present tide levels is calculated as (Shennan 1986; Van de Plassche 1986):

$$
\mathrm{SLIP}=\mathrm{H}-\mathrm{D}-\mathrm{I}+\mathrm{C}+\mathrm{A}
$$


2 where $\mathrm{H}$ is the height of the top core, $\mathrm{D}$ is the depth of the sample, $\mathrm{I}$ is the heigh of the deposition of 3 the sample (indicative meaning), $\mathrm{C}$ is the core compaction, and $\mathrm{A}$ is the autocompaction (loss of 4 porosity due to the load of overlying sediments). This latter parametter strongly affects the calculation 5 of the SLIP position, especially for samples from unconsolidated peat successions (Gehrels 1999), yet 6 is particularly hard to estimate (Allen 1999, 2000; Long et al. 2006; Edwards 2006; Massey et al. 7 2006, 2008). Consequently, most of Holocene sea-level studies focus mainly on basal samples to infer 8 compaction effects (e.g. Denys \& Baeteman 1995; Van de Plassche 1995; Gehrels 1999; Shennan \& 9 Horton 2002; Berendsen 2007) and consider the intercalated SLIP simply as an approximation.

From the 26 AMS ${ }^{14} \mathrm{C}$ dates obtained in this study, 12 were used to produce SLIPs with a 11 indicative meaning defined by the palaeomarsh surface elevation reconstructed by the FBTFs models 12 (Fig. 10). Two dates obtained at the base of the basal brackish peat of Tresseny were also used as basal 13 SLIPs, assuming an indicative meaning ranging from the HAT to the MHWNT (Goslin et al. 2013). 14 Results indicate a rise of the RSL around $5.5 \mathrm{~m}$ during the last $6300 \mathrm{cal}$. a within the northwest coasts 15 of Brittany. The mean rate of RSL rise calculated by a linear regression with all SLIPs $\left(\mathrm{r}^{2}=0.97\right)$ is of $0.90 \pm 0.12 \mathrm{~mm} \mathrm{a}^{-1}$ for the entire period.

A comparison between SLIPs produced in this study and previous RSL data obtained from Brittany is presented in Fig. 10. Most of previous data were converted into SLIPs using the same methodological approach as Leorri et al. (2012). We use the indicative meaning reported in original publications. Local tide ranges used for coastal sites are presented in Table 1 and details about SLIPs 21 produced are given in Table 4. Radiocarbon dates were also calibrated using the IntCal13 calibration 22 curve (Reimer et al. 2013) to allow comparisons with our results. Fig. 10 illustrates that the SLIPs produced in this paper are consistent with previous RSL records and improve precision from c.6500 cal. a BP. Despite the wide incertitude boxes drawn for the previous data, a vertical variability 25 between the SLIP is visually observed between the sites located at the SE part of Brittany and the 26 points obtained in the NE and NW parts of Brittany. Lambeck (1997), followed by Leorri et al. (2012) 27 highlighted the evident north-south trend in the Hococene sea-level rise in the Gulf of Biscay, mainly 28 due to the ice-induced signal (glacio-isostacy) producing a relatively long-wavelength pattern with a 
1 dominant north/south gradient. However, according to Leorri et al. (2012), the ocean-induced signal

2 (hydro-isostacy) produces spatial gradients that are perpendicular to the shoreline, due to the geometry 3 of the ocean loading. As a peninsula, Brittany appears to be an appropriate area to study the ocean4 induced signal in detail. However, exploring this question along the coast of Brittany remains difficult 5 in the state of our knowledge because of the lack of available basal SLIPs (only 10) providing reliable 6 altitudinal sea-level data, notably in the eastern part of Brittany.

Salt-marshes evolution

Based on the lithostratigraphical and biostratigraphical analyses, a general pattern of Holocene salt11 marsh evolution subdivided into four stages is proposed for West Britanny.

Stage 1: Basal peat formation (6400 to 4500 cal. a BP). - From 6400 to 4500 cal. a BP, extensive Phragmites marshes were formed around the present-day shoreline position. They expanded laterally and vertically under the influence of a rising water table until they reached an elevation of about $0 \mathrm{~m}$ 16 NGF or more. In Tresseny salt-marsh, only scarce foraminifera were present in the basal peat, 17 reflecting freshwater or brackish conditions. During this first stage of sedimentary infilling, the bay of 18 Tresseny was probably separated from the sea by the presence of a wide coastal dune barrier located 19 further seaward. In the bay of Brest, Phragmites macro-remains were not encountered and high-marsh 20 foraminifera species such as $J$. macrescens and $T$. inflata were broadly present in the basal peat units. 21 This reflects the influence of the tide in a high salt-marsh environment. Our results are consistent with 22 those obtained by Morzadec-Kerfourn (1975) and more recently by Goslin et al. (2013) on the 23 northern and southern coasts of the Finistère region: the base of a brackish basal peat found on the 24 Vougot beach (Fig. 1) at an elevation of $-3.52 \mathrm{~m} \mathrm{NGF}$ gave an age of 6880 cal. a BP, while a similar 25 deposit found at Tariec beach was dated around 6850 cal. a BP at an elevation of $-3.80 \mathrm{~m}$ NGF (Goslin 26 et al. 2013). In a general manner, it indicates that the formation of extensive reed and/or brackish 27 marshes began around 6900 cal. a BP in places within the northwestern part of Brittany, under the 28 joint influence of rising water table and stabilization of barrier systems on the foreshore. These 
1 deposits are also associated with the presence of numerous coastal archaeological remains (megalithic

2 gallery graves and menhirs) attributed to the neolithic period such as the gallery grave of Lerret,

3 located $500 \mathrm{~m}$ seaward from Tresseny salt-marsh and dated about 4800-5000 cal. a BP.

4

5 Stage 2: Formation of backbarrier salt-marshes (4500 to 2900-2700 cal. a BP). - Over the basal peats,

6 an accumulation of clayey peat deposits indicates salt-marsh expansion from 4500 cal. a BP, probably

7 behind gravelly or sandy barriers offering sheltered conditions for high-marsh development. In the

8 sediment successions of the bay of Brest, the transition from basal peat is gradual and the

9 reconstructed palaeosurfaces are around the MHWST. At Tresseny, deposits corresponding to this

10 stage were not preserved; however it is possible that brackish conditions were maintained behind a

11 large coastal dune barrier.

12

13 Stage 3: Deep reorganization of back-barrier sedimentary wedges (2900-2700 cal. a BP). - Around 14 2900-2700 cal. a BP, the sediment successions reveal that coastal sedimentary systems underwent 15 deep modifications. At Tresseny, this stage corresponded to the erosion of the top of the basal peat 16 layer and the deposition of a coarse sand layer, overlayed by a silty-sand deposit. In the bay of Brest, 17 Troaon and Arun marshes revealed layers of silty-sand deposits corresponding to this period at an 18 average elevation of around 0 to $+1 \mathrm{~m}$ NGF. At Troaon, these layers contain shell fragments and rest 19 unconformably over the high-marsh clayey peat. The dominance of hyaline species such as $H$. 20 germanica and Elphidium sp. indicates a low salt-marsh depositional environment estimated around 21 the MTL by the transfer function. Conversely, the Porzguen marsh revealed no discontinuities within 22 the sedimentary succession, most likely due to its sheltered location.

23 At the scale of northwest Europe, the period around 3000 cal. a BP has been widely 24 recognized as a period of climate deterioration (Van Geel et al. 1996; Barber et al. 2003, 2004; Magny 25 2004; Dark 2006; Gandouin et al. 2009; Charman 2010; Swindles et al. 2013; Tisdall et al. 2013), 26 characterized by colder and wetter climatic conditions, with increased rainfall and largely enhanced 27 storminess (Van Geel et al. 1996; Clark \& Rendell 2009). Major disruptions of coastal sedimentary 28 environments were also identified all along the European coasts, either in the English Channel region 
1 (Long \& Hughes 1995; Billeaud et al. 2009; Sorrel et al. 2009; Lespez et al. 2010; Tessier et al. 2012)

2 or along the Atlantic coasts (Pontee et al. 1998; Tastet \& Pontee 1998; Clavé et al. 2001; Moura et al.

3 2007; Sorrel et al. 2009). Archaeological remains suggest less dense settlement patterns at the end of

4 the Late Bronze Age (Coquillas 2001; Pailler et al. 2011; Stéphan et al. 2013) and for several

5 settlements abandonment, notably due to an important eolian activity within the northwest Europe

6 coastal areas (Guilcher \& Hallégouët 1991; Tisdall et al. 2013).

Hence, we explain the genesis of these erosive contacts and sedimentary hiatus by high-energy conditions having taking place around 3000 cal. a BP, either caused by storm events, reorganization of

9 the back-barrier marsh drainage systems, or under the joint influence of both dynamics. We believe that several morphogenetic scenarios can be invoked:

(i) Severe storms could have caused major breaches in the barrier systems, erosion of back-barrier sedimentary succession and deposition of mixed material displaced from the foreshore domain (deposits of "Chenier" type). This scenario well suits the sedimentary succession of the Arun marsh, but appears largely unconvincing for the inner-estuary Tresseny marsh and so cannot be considered as regionally valid.

likely reveals the onset of inner-estuary conditions around $3000 \mathrm{cal}$. a BP. At this period, coastal streams valleys may have been widened to answer the waterflow increasements that followed the onset of wetter conditions in the context of (i) considerably reduced slopes of the streams-flows due to deeper intrusions of the salt-wedges and (ii) important terrigenous infillings in the lower valley systems induced by the massive clearings that took place during the Iron age (Dark 2006).

(iii) Third, barrier breaching may have fostered the catchment of the tidal channels within 23 the marshes and in turn induced an erosion of the sedimentary successions. Tidal flows within the 24 marshes may have gained volume in response to barrier-breachings (Wang et al. 2000; Picado et al. 25 2013) and in turn, resulted in the incision of tidal channels as it was shown by Cleveringa (2000).

26 These morphodynamic processes are of primary importance as soon as RSL reconstruction is 27 concerned. In fact, as proposed by Goslin et al. (2013), high morphogenic events could have 28 artificially created accommodation space, subsequently infilled by sedimentary deposits of doubtful 
1 origin. Thus, we consider that large uncertaintities remaining on the representativeness of the $c .2800$

2 cal. a BP points we obtained within the Arun and Tresseny successions.

3

4 Stage 4: Formation of new salt-marshes (2700 cal. a BP to present). - A return of the high salt-marsh

5 environment, after the deposition of the silty-sand units is reflected by foraminiferal assemblages

6 dominated by J. macrescens and T. inflata. Gravel barriers of Troaon and Arun were rebuilt in front of

7 the salt-marshes, gradually accreting until today. At Arun, two washover deposits were recognized

8 throughout the sediment succession, probably related to episodic landward retreat of the gravel spit

9 during storms. However, contrary to the 2900-2700 cal. a BP period, no major and synchronous

10 phases of erosion were observed in the succession we studied. In the inner part of the bay of Tresseny,

11 the formation of the salt-marsh began around 1820-1690 cal. a BP with the gradual colonization of the

12 sand-flat environment by halophitic plants and the abundance of agglutinated foraminifera.

\section{Conclusions}

15

16

17

In order to improve the reconstructions of relative sea-level changes for the late Holocene period in Brittany (western France), foraminifera-based transfer functions were developed using total assemblages from 77 samples collected along three cross-marsh transects located in two coastal bays (bay of Brest and the bay of Tresseny) in the most western part of Brittany. In the bay of Tresseny, we used the whole training set (all samples and all species) to produce a WAPLS model with a RMSEP of $\pm 0.14 \mathrm{~m}$ and $\mathrm{r}^{2}$ of 0.90 . In the bay of Brest, three models were successively developped by removing modern samples from mudflat, followed by tidal creeks and salt-pans in order to increase the transfer function's predictive ability. The resulting final WAPLS model has a RMSEP of $\pm 0.20 \mathrm{~m}$ and $\mathrm{r}^{2}$ of 0.94 .

The mid- to late Holocene stratigraphy of four salt-marshes developed over the past $6500 \mathrm{cal}$. a BP in the bay of Brest and in the bay of Tresseny was studied by litho- and biostratigraphical analyses. These investigations give, for the first time, a chronological pattern of Holocene infill of small salt-marshes in western France. Sediment successions show (i) basal peat units indicating 
1 extensive reed marshes between 6400 and $4500 \mathrm{cal}$. a BP, (ii) clayey peat deposits dominated by high-

2 marsh foraminiferal assemblages corresponding to the expansion of salt-marshes into backbarrier 3 environments between 4500 and 3600 cal. a BP, (iii) storm-induced deposits around 2900-2700 cal. a

4 BP represented by a coarse sand layer in the Tresseny sediment succession, and by silty-sand layers

5 containing shell fragments and hyaline species such as H. germanica and Elphidium sp. in the bay of

6 Brest sediment successions and (iv) a return of high salt-marsh environment since 2700 cal. a BP,

7 reflected by foraminiferal assemblages dominated by J. macrescens and T. inflata.

The application of transfer function models to fossil assemblages produced 14 new sea-level

9 index points showing a relative sea-level rise of $5.5 \pm 0.5 \mathrm{~m}$ during the last 6300 years, at a mean rate of

$10 \quad 0.90 \pm 0.12 \mathrm{~mm} \mathrm{a}^{-1}$. New data obtained in this study improve the vertical definition of the Holocene

11 relative sea-level history along the coasts of West Brittany and convey new information on the late

12 Holocene period. Nonetheless, further research is still required (i) to achieve a better understanding of

13 the behavior of the sedimentary systems in the context of descelerating RSL rise, (ii) to better

14 constrain the history of the last c. 3000 years and (iii) to estimate the influence of the hydro-isostatic

15 signal on the Holocene trends of the RSL rise along the western coasts of France.

16

Acknowledgements.- This work is a contribution to the Archaeological Program of Molene Archipelago (funded by Regional Service of Archaeology of Brittany) and to the ANR program "Cocorisco" (French National Research Agency program for coastal risks assessment and management, ANR 2010-CEPL-001-01, Pôle-mer Bretagne). Special aknowledgements are given to Nicolas Gudicelli for field assistance and Elaine Harkin for her help in proof-reading the article. The authors acknowledge N. Barlow and an anonymous reviewer for their constructive remarks.

\section{References}

Allen, J.R.L. 1999: Geological impacts on coastal wetland landscape: some general effect of sediment autocompaction in the Holocene of northwest Europe. The Holocene 1, 1-12. 
1 Allen, J.R.L. 2000: Holocene coastal lowlands in NW Europe: autocompaction and the uncertain

2 ground. In Pye, K. \& Allen, J.R.L. (eds.): Coastal and Estuarine Environments: sedimentology,

3 geomorphology and geoarchaeology, 239-252. Geological Society, London, Special Publication 175.

4

5 Allen, J.R.L. 2003: An eclectic morphostratigraphic model for the sedimentary response to Holocene

6 sea-level rise in northwest Europe. Sedimentary Geology 161, 31-54.

7

8 Alve, E. \& Murray, J.W. 1994: Ecology and taphonomy of benthic foraminifera in a temperate 9 mesotidal inlet. Journal of Foraminiferal Research 24, 18-27.

10

11 Armynot du Châtelet, E., Debenay, J.-P., Degré, D. \& Sauriau, P.-G. 2005: Utilisation des 12 foraminifères benthiques comme indicateurs de paléo-niveaux marins? Etude du cas de l'anse de 13 l'Aiguillon. Comptes Rendus Palévol 4, 209-223.

14

15 Barber, K.E., Chambers, F.M. \& Maddy, D. 2003: Holocene palaeoclimates from peat stratigraphy: 16 macrofossil proxy climate records from three oceanic raised bogs in England and Ireland. Quaternary 17 Science Reviews 22, 521-539.

Barber K.E., Chambers F.M. \& Maddy D. 2004: Late Holocene climatic history of northern Germany 20 and Denmark: peat macrofossil investigations at Dosenmoor, Schleswig-Holstein, and Svanemose, 21 Jutland. Boreas 33, 132-144.

Barlow, N.L.M., Shennan, I., Long, A.J., Gehrels, W.R., Saher, M.H., Woodroffe, S.A. \& Hillier, C. 24 2013: Salt marshes as late Holocene tide gauges. Global and Planetary Change 106, 90-110. 25

26 Berendsen, H.J.A., Makaske, B., Van de Plassche, O., Van Ree, M.H.M., Das, S., Van Dongen, M., 27 Ploumen, S. \& Schoenmakers, W. 2007: New groundwater-level rise data from the Rhine-Meuse delta 
1 -implications for the reconstruction of Holocene relative mean sea-level rise and differential land-

2 level movements. Netherlands Journal of Geosciences 86, 333-354.

3

4 Billeaud, I., Tessier, B., Lesueur, P. \& Caline, B. 2007: Preservation potential of highstand coastal

5 sedimentary bodies in a macrotidal basin: Example from the Bay of Mont-Saint-Michel, NW France.

6 Sedimentary Geology 202, 754-775.

7

8 Billeaud, I., Tessier, B. \& Lesueur, P. 2009: Impacts of Late Holocene rapid climate changes as

9 recorded in a macrotidal coastal setting (Mont-Saint-Michel Bay, France). Geology 37, 1031-1034.

Birks, H.J.B. 1995: Quantitative paleoenvironmental reconstructions. In Maddy, D. \& Brew, J.S. 12 (eds.): Statistical Modelling of Quaternary Science Data, Technical Guide 5, 161-254. Quaternary 13 Research Association, Cambridge.

14

15 Boomer, I. \& Horton, B.P. 2006: Holocene relative sea-level movements along the North Norfolk 16 Coast, UK. Palaeogeography, Palaeoclimatology, Palaeoecology 230, 32-51.

Charman, D.J. 2010: Centennial climate variability in the British Isles during the mid-late Holocene. Quaternary Science Reviews 29, 1539-1554.

Clarke, M.L. \& Rendell, H.M. 2009: The impact of North Atlantic storminess on western European coasts: A review. Quaternary International 195, 31-41.

Clavé, B., Massé, L., Carbonel, P. \& Tastet, J.-P. 2001: Holocene coastal changes and infilling of the 25 La Perroche marsh (French Atlantic coast). Oceanologica Acta 24, 377-89.

27 Cleveringa, J. 2000: Reconstruction and modelling of Holocene coastal evolution of the western 28 Netherlands. Ph.D. thesis, University of Utrecht, 198 pp. 
2 Coquillas, D. 2001: Les rivages de l'estuaire de la Gironde du Néolithique au Moyen Age. Ph.D.

3 thesis, University of Bordeaux, $1296 \mathrm{pp}$.

4

5 Dark, P. 2006: Climate deterioration and land-use change in the first millennium BC: perspectives

6 from the British palynological record. Journal of Archaeological Science 33, 1381-1395.

7

8 Debenay, J.-P., Bicchi, E., Goubert, E. \& Armynot du Châtelet, E. 2006: Spatio-temporal distribution

9 of benthic foraminifera in relation to estuarine dynamics (Vie estuary, Vendée, W France). Estuarine,

$10 \quad$ Coastal and Shelf Science 67, 181-197.

11

12 Delibrias, G., Guillier, M.T. \& Labeyrie, J. 1982: Gif natural radiocarbon measurements IX. 13 Radiocarbon 24, 291-343.

14

15 Denys, L. \& Baeteman, C. 1995: Holocene evolution of relative sea level and local mean high water 16 spring tides in Belgium - a first assessment. Marine Geology 124, 1-19.

17

18 Duchemin, G., Jorissen, F.J., Redois, F. \& Debenay, J.-P. 2005: Foraminiferal microhabitats in a high 19 marsh: consequences for reconstructing past sea levels. Palaeogeography, Palaeoclimatology, 20 Palaeoecology 226, 167-185.

Edwards, R.J. 2001: Mid- to late Holocene relative sea-level change in Poole Harbour, southern England. Journal of Quaternary Science 16, 221-235.

24

25 Edwards, R.J. \& Horton, B.P. 2000: Reconstructing relative sea-level change using UK salt-marsh 26 foraminifera. Marine Geology 169, 41-56. 
1 Edwards, R.J. \& Horton, B.P. 2006: Developing detailed records of relative sea-level change using a

2 foraminiferal transfer function: an example from North Norfolk, UK. Philosophical Transactions of 3 the Royal Society 364, 973-991.

4

5 Edwards, R.J. 2006: Mid- to late-Holocene relative sea-level change in southwest Britain and the 6 influence of sediment compaction. The Holocene 16, 575-587.

8 Gandouin, E., Ponel, P., Andrieu-Ponel, V., Guiter, F., de Beaulieu, J.L., Djamali, M., Franquet, E., 9 Van Vliet-Lanoë, B., Alvitre, M., Meurisse, M., Brocandel, M. \& Brulhet, J. 2009: 10,000 years of 10 vegetation history of the Aa palaeoestuary, St-Omer Basin, northern France. Review of Palaeobotany 11 and Palynology 156, 307-318.

12

Gaudin, L. 2004: Transformations spatio-temporelles de la végétation du nord-ouest de la France depuis la fin de la dernière glaciation. Reconstitutions paléo-paysagères. Ph.D.thesis, University of 15 Rennes 1, $762 \mathrm{pp}$.

16

Gehrels, W.R. 1999: Middle and late Holocene sea-level changes in eastern Maine reconstructed from foraminiferal saltmarsh stratigraphy and AMS 14C dates on basal peat. Quaternary Research 52, 350359.

Gehrels, W.R., Belknap, D.F. \& Kelley, J.T. 1996: Integratedhigh-precision analyses of Holocene relative sea-level changes:Lessons from the coast of Maine. Geological Society of America Bulletin $108,1073-1088$.

Gehrels, W.R., Roe, H.M. \& Charman, D.J. 2001: Foraminifera, testate amoebae and diatoms as sea26 level indicators in UK saltmarshes: a quantitative multiproxy approach. Journal of Quaternary Science $27 \quad 16,201-220$. 
1 Giot, P.-R. 1969: Chronique des datations radiocarbone armoricaines. Annales de Bretagne 76, 153-

2162.

3

4 Goldstein, S.T., Watkins, G.T. \& Kuhn, R.M. 1995: Microhabitats of salt marsh foraminifera: St.

5 Catherines Island, Georgia, USA. Marine Micropaleontology 26, 17-29.

6

7 Goldstein, S.T. \& Watkins, G.T. 1999: Taphonomy of salt marsh foraminifera: an example from 8 coastal Georgia. Palaeogeography, Palaeoclimatology, Palaeoecology 149, 103-114.

9

10 Goslin, J., Van Vliet-Lanoë, B., Stephan, P., Delacourt, C., Fernane, A., Gandouin, E., Hénaff, A., 11 Penaud, A. \& Suanez, S. 2013: Holocene relative sea level changes in western Brittany (France) 12 between 8000 and 4000 cal.yr B.P: reconstitution from basal-peat deposits. Géomorphologie: reliefs, 13 processus, environnements 4, 425-444.

14

15 Goslin, J. 2014: Holocene relative sea-level reconstructiuon in the Finistère region (Brittany, 16 France): regional dynamics, local responses. Ph.D. thesis, University of Brest, 355 pp.

Goubert, E. 1997: Les Elphidium excavatum (Terquem), foraminifères benthiques, vivants en baie de Vilaine (Bretagne, France) d'octobre 1992 à septembre 1996: morphologie, dynamique de population 20 en relation avec l'environnement. Ph.D. thesis, University of Nantes, 186 pp.

Guilcher, A., Bodéré, J.-C. \& Hallégouët, B. 1990: Coastal evolution in western, southestern and northern Brittany as a regional test of impact of sea level rise. Journal of Coastal Research 9, 67-90. 
1 Hallégouët, B. 1971: Le Bas-Léon. Etude géomorphologique. Ph.D. thesis, University of Brest, 347

2 pp.

3

4 Hamilton, S. \& Shennan, I. 2005: Late Holocene relative sea-level changes and the earthquake

5 deformation cycle around upper Cook Inlet, Alaska. Quaternary Science Reviews 24, 1479-1498.

7 Hayward, B.W., Holzmann, M., Grenfell, H.R., Pawlowski, J. \& Triggs, C.M. 2004: Morphological

8 distinction of molecular types in Ammonia - towards a taxonomic revision of the world's most

9 commonly misidentified foraminifera. Marine Micropaleontology 50, 237-271.

Hippensteel, S.P., Martin, R.E., Nikitina, D. \& Pizzuto, J. 2000: The transformation of Holocene

12 marsh foraminifera assemblages, Middle Atlantic Coast, USA: implications for Holocene sea-level 13 changes. Journal of Foraminiferal Research 30, 272-293.

14

15 Horton, B.P. \& Edwards, R.J. 2003: Seasonal distributions of foraminifera and their implications for 16 sea-level studies, Cowpen Marsh, U.K. In Olson, H.C. \& Leckie, R.M. (eds.): Micropaleontologic 17 proxies for sea-level change and stratigraphic discontinuities, 21-30. SEPM Special Publication 75.

Horton, B.P. \& Edwards, R.J. 2005: The application of local and regional transfer functions to the 20 reconstruction of Holocene sea levels, north Norfolk, England. The Holocene 15, 216-228.

Horton, B.P. \& Edwards, R.J. 2006: Quantifying Holocene sea-level change using intertidal 23 foraminifera: lessons from the British Isles. Cushman Foundation for Foraminiferal Research 40, 197.

Horton, B.P., Edwards, R.J. \& Lloyd, J.M. 2000: Implications of a microfossil-based transfer function 27 in Holocene sea-level studies. In Shennan, I. \& Andrews, J. (eds.): Holocene land-ocean interaction 
1 and environmental change around the North Sea, 41-54. Geological Society, London, Special

2 Publication 166.

3

4 Juggins, S. 2004: C2, Version1.4. WWW Page. Newcastle University, UK.

5 http://www.campus.ncl.ac.uk/staff/Stephen.Juggins/index.html.

6

7 Kemp, A.C., Horton, B.P., Vann, D.R., Engelhart, S.E., Grand Pre, C.A., Vane, C.H., Nikitina, D. \&

8 Anisfeld, S.C. 2012: Quantitative vertical zonation of salt-marsh foraminifera for reconstructing

9 former sea level; an example from New Jersey, USA. Quaternary Science Reviews 54, 26-39.

10

11 Lambeck, K. 1997: Sea-level change along the French Atlantic and Channel coast since the time of the 12 Last Glacial Maximum. Palaeogeography, Palaeoclimatology, Palaeoecology 129, 1-22.

14 Leorri, E., Horton, B.P. \& Cearreta, A. 2008a: Development of a foraminifera-based transfer function 15 in the Basque marshes, N. Spain : implications for sea-level studies in the Bay of Biscay. Marine 16 Geology 251, 60-74.

17

Leorri, E., Cearreta, A. \& Horton, B.P. 2008b: A foraminifera-based transfer function as a tool for sealevel reconstructions in the southern Bay of Biscay. Geobios 41, 787-797.

Leorri, E., Gehrels, W.R., Horton, B.P., Fatela, F. \& Cearreta, A. 2010: Distribution of foraminifera in 22 salt marshes along the Atlantic coast of SW Europe: Tools to reconstruct past sea-level variations. Quaternary International 221, 104-115.

24

25 Leorri, E., Fatela, F., Cearreta, A., Moreno, J., Antunes, C. \& Drago, T. 2011: Assessing the 26 performance of a foraminifera-based transfer function to estimate sea-level changes in northern 27 Portugal. Quaternary Research 75, 278-287. 
1 Leorri, E., Cearreta, A. \& Miles, G. 2012: Field observations and modelling of Holocene sea-level

2 changes in the southern Bay of Biscay: implication for understanding current rates of relative sea-level 3 change and vertical land motion along the Atlantic coast of SW Europe. Quaternary Science Reviews $4 \quad 42,59-73$.

5

6 Lespez, L., Clet-Pellerin, M., Davidson, R., Hermier, G., Carpentier, V. \& Cador, J.-M. 2010: Middle

7 to Late Holocene landscape changes and geoarchaeological implications in the marshes of the Dives

8 estuary (NW France). Quaternary International 216, 23-40.

9

10 Long, A.J. \& Hughes, P.D.M. 1995: Mid- and late-Holocene evolution of the Dungeness foreland, 11 UK. Marine Geology 124, 253-271.

12

13 Long, A.J., Waller, M.P. \& Stupples, P. 2006: Driving mechanisms of coastal change: peat 14 compaction and the destruction of late Holocene coastal wetlands. Marine Geology 225, 63-84.

15

16 17 18

Magny, M. 2004: Holocene climate variability as reflected by mid-European lake-level fluctuations and its probable impact on prehistoric human settlements. Quaternary International 113, 65-79.

Massey, A.C., Gehrels, W.R., Charman, D.J. \& White, S.V. 2006: An intertidal foraminifera-based transfer function for reconstructing Holocene sea-level change in Southwest England. Journal of Foraminiferal Research 36, 215-232.

Massey, A.C., Gehrels, W.R., Charman, D.J., Milne, G.A., Peltier, W.R., Lambeck, K. \& Selby, K.A. 2008: Relative sea-level change and postglacial isostatic adjustment along the coast of south Devon, United Kingdom. Journal of Quaternary Science 23, 415-433. 
1 Morzadec-Kerfourn, M.-T. 1969: Variations de la ligne de rivage au cours du post-glaciaire le long de

2 la côte nord du Finistère. Analyses polliniques de tourbes et de dépôts organiques littoraux. Bulletin de

3 l'Association Française pour l'Etude du Quaternaire 4, 285-318.

4

5 Morzadec-Kerfourn, M.-T. 1975: Evolution paléogéographique du marais de Dol-de-Bretagne (Ille-et-

6 Vilaine) durant le Flandrien. Bulletin de la Société Geologique et Minéralogique de Bretagne 7, 49-51.

8 Morzadec-Kerfourn, M.T. 1995: Coastline changes in the Armorican Massif (France) during the 9 Holocene. Journal of Coastal Research 17, 197-203.

10

11 Moulinier, M. 1966: Variabilité d'une population d'Elphidium de la rade de Brest (Nord Finistère) 12 apparentés à Elphidium crispum (Linné). Revue de Micropaléontologie 9, 124-200.

14 Moura, D., Veiga-Pires, L., Albardeiro, T., Boski, T., Rodrigues, A.L. \& Tareco, H. 2007: Holocene 15 sea level fluctuations and coastal evolution in the central Algarve (southern Portugal). Marine Geology $16 \quad 237,127-142$.

Pailler, Y., Stéphan, P., Gandois, H., Nicolas, C., Sparfel, Y., Tresset, A., Donnart, K., Dréano, Y., 19 Fichaut, B., Suanez, S., Dupont, C., Le Clézio, L., Marcoux, N., Pineau, A., Salanova, L., Sellami, F., 20 Debue, K., Josselin, J. \& Dietsch-Sellami, M.-F. 2011: Evolution des paysages et occupation humaine 21 en mer d'Iroise (Finistère, Bretagne) du Néolithique à l'Âge du Bronze. Norois 220, 39-68.

Patterson, R.T., Guilbault, J.P. \& Clague, J.J., 1999: Taphonomy of tidal foraminifera: implications of 24 surface sample thickness for high-resolution sea-level studies. Palaeogeography, Palaeoclimatology, 25 Palaeoecology 149,199-211.

27 Picado, A., Lopes, C.L., Mendes, R., Vaz, N. \& Dias, J.M. 2013: Storm surge impact in the 28 hydrodynamics of a tidal lagoon: the case of Ria de Aviero. In Conley, D.C., Masselink, G., Russell, 
1 P.E. \& O'Hare, T.J. (eds.): Proceedings 12th International Coastal Symposium (Plymouth, England),

2 796-801. Journal of Coastal Research, Special Issue 65.

3

4 Pontee, N.I., Tastet, J.P. \& Massé, L. 1998: Morpho-sedimentary evidence of Holocene coastal 5 changes near the mouth of the Gironde and on the Medoc Peninsula, SW France. Oceanologica Acta $6 \quad 21,243-261$.

8 Redois, F. \& Debenay, J.-P. 1996: Influence du confinement sur la répartition des foraminifères 9 benthiques: exemple de l'estran d'une ria mésotidale de Bretagne méridionale. Revue de Paléobiologie $10 \quad 15,243-260$.

Reimer, P.J., Bard, E., Bayliss, A., Beck, J.W., Blackwell, P.J., Ramsey, C.B., Buck, C.E., Cheng, H., 13 Edwards, R.L., Friedrich, M., Grootes, P.M., Guilderson, T.P., Haflidason, H., Hajdas, I., Hatte, C., 14 Heaton, T.J., Hoffmann, D.L., Hogg, A.G., Hughen, K.A., Kaiser, K.F., Kromer, B., Manning, S.W., 15 Niu, M., Reimer, R.W., Richards, D.A., Scott, E.M., Southon, J.R., Staff, R.A. Turney, C.S.M. \& Van 16 Der Plicht, J. 2013: Intcal13 and Marine13 radiocarbon age calibration curves 0-50,000 years cal BP. 17 Radiocarbon 55, 1869-1887. Edition, Berlin.

Rossi, V., Horton, B.P., Corbett, D.R., Leorri, E., Perez-Belmonte, L. \& Douglas, B.C. 2011: The application of foraminifera to reconstruct the rate of 20th century sea level rise, Morbihan Golfe, Brittany, France. Quaternary Research 75, 24-35.

Saffert, H. \& Thomas, E. 1998: Living foraminifera and total populations in salt marsh peat cores:

27 Kelsey Marsh (Clinton, CT) and the Great Marshes (Barnstable, MA). Marine Micropalaeontology 33, $28 \quad 175-202$. 
2 Sejrup, H.P., Birks, H.P.B., Kristensen, D.K. \& Madsen, H. 2004: Benthonic foraminiferal 3 distributions and quantitative transfer functions for the northwest European continental margin. 4 Marine Micropalaeontology 53, 197-226.

5

6 Shennan, I. 1986: Flandrian sea-level changes in the Fenland I. The geographical setting and evidence 7 of relative sea-level changes. Journal of Quaternary Science 1, 119-54.

9 Shennan, I. \& Horton, B.P. 2002: Holocene land- and sea-level changes in Great Britain. Journal of 10 Quaternary Science 17, 511-526.

SHOM. 2013: Marine Altimetric References, Cotes du zéro hydrographique et niveaux 13 caractéristiques de la marée. 113 pp. Edition SHOM, Brest.

15 Sorrel, P., Tessier, B., Demory, F., Delsinne, N. \& Mouazé, D. 2009: Evidence for millennialscale 16 climatic events in the sedimentary infilling of a macrotidal estuarine system, the Seine estuary (NW 17 France). Quaternary Science Reviews 28, 499-516. Sorrel, P., Tessier, B., Demory, F., Baltzer, A., Bouaouina, F., Proust, J.-N., Menier, D. \& Traini, C. 20 2010: Sedimentary archives of the French Atlantic coast (inner Bay of Vilaine, south Brittany): 21 Depositional history and late Holocene climatic and environmental signals. Continental Shelf 22 Research 30, 1250-1266.

24 Stéphan, P. 2011a: Colmatage sédimentaire des marais maritimes et variations relatives du niveau 25 marin au cours des 6000 dernières années en rade de Brest (Finistère). Norois 220, 9-37.

27 Stéphan, P. 2011b: Les flèches de galets de Bretagne: évolution passée, présente et future. 263 pp. 28 L'Harmattan, Paris. 
2 Stéphan, P. 2011c: Quelques données nouvelles sur la mobilité récente et le bilan sédimentaire des

3 flèches de galets de Bretagne. Géomorphologie: reliefs, processus, environnements 2, 205-232.

4

5 Stéphan, P., Pailler, Y., Tresset, A. \& Gandois, H. 2013: Changements paléogéographiques de 6 l'archipel de Molène (Finistère, Bretagne, France): implications sur les peuplements humains du 7 Néolithique à l'Age du Bronze. In Daire, M.-Y., Dupont, C., Baudry, A., Billard, C., Large, J.-M., 8 Lespez, L., Normand, E. \& Scarre, C. (eds.): Ancient maritime communities and the relationship 9 between people and environment along the European Atlantic coasts, 647-660. Proceedings of the HOMER 2011 Conference, British Archaeological Reports, International Series, Oxford.

12 Stuiver, M. \& Reimer, P.J. 1993: Extended ${ }^{14} \mathrm{C}$ data base and revised CALIB.3.0. ${ }^{14} \mathrm{C}$ age calibration 13 program. Radiocarbon 35, 215-230.

15 Suanez, S., Dehouck A. \& Stéphan, P. 2008: Incertitude de la mesure de terrain en géomorphologie 16 littorale. Approche statistique et quantification des marges d'erreur. In Allard, P., Fox, D. \& Picon, B. 17 (eds.): Incertitude et environnement, la fin des certitudes scientifiques, 127-139. Edition EDISUD, 18 Aix-en-Provence.

Swindles, G.T., Lawson, I.T., Matthews, I.P., Blaauwc, M., Daley, T.J., Charman, D.J., P.Rolandf, T., Plunkett, G., Schettler, G., Gearey, B.R., Turner, T.E., Rea, H.A., Roe, H.M., Amesbury, M.J., Chambers, F.M., Holmes, J., Mitchell, F.J.G., Blackford, J., Blundell, A., Branch, N., Holmes, J., 24 Young, D., Wheeler, J., Becker, K. \& Armit, I. 2013: Centennial-scale climate change in Ireland 25 during the Holocene. Earth-Science Reviews 126, 300-320.

27 Tastet, J.P. \& Pontee, N.I. 1998: Morpho-chronology of coastal dunes in Médoc. A new interpretation 28 of Holocene dunes in Southwestern France. Geomorphology 25, 93-109. 
1 Ter Braak, C.J.F. \& Smilauer, P. 1998: CANOCO Reference Manual and User's Guide to Canoco for

2 Windows: Software for Canonical Community Ordination (Version 4). 500 pp. Microcomputer Power, 3 New York.

4

5 Ters, M. 1986: Variations in Holocene sea-level on the french Atlantic coast and their climatic 6 significance. In Rampino, M.R., Sanders, J.E., Newman, W.S. \& Königsson, L.K. (eds.): Climate: 7 history, periodicity and predictability, 204-237. Van Nostrand Reinhold, New York.

9 Tessier, B., Delsinne, N. \& Sorrel, P. 2010a: Holocene sedimentary infilling of a tidedominated 10 estuarine mouth. The example of the macrotidal Seine estuary (NW France), Bulletin de la Société 11 Geologique de France 181, 87-98.

Tessier, B., Billeaud, I. \& Lesueur, P. 2010b: Stratigraphic organization of a composite macrotidal wedge: the Holocene sedimentary infill of the Mont-Saint-Michel Bay. Bulletin de la Société Geologique de France 181, 99-113.

Tessier, B., Billeaud, I., Sorrel, P., Delsinne, N. \& Lesueur, P. 2012: Infilling stratigraphy of 18 macrotidal tide-dominated estuaries. Controlling mechanisms: Sea-level fluctuations, bedrock 19 morphology, sediment supply and climate changes (The examples of the Seine estuary and the Mont20 Saint-Michel Bay, English Channel, NW France). Sedimentary Geology 279, 62-73.

Tisdall, E.W., McCulloch, R.D., Sanderson, D.C.W, Simpson, I.A. \& Woodward, N.L. 2013: Living with sand: A record of landscape change and storminess during the Bronze and Iron Ages Orkney, Scotland. Quaternary International 308-309, 205-215.

26 Törnqvist, T.E., Van Ree, M.H.M., Van’t Veer, R. \& Van Geel, B. 1998: Improving methodology for 27 high-resolution reconstruction of sea-level rise and neotectonics by paleoecological analysis and AMS $28{ }^{14} \mathrm{C}$ dating of basal peats. Quaternary Research 49, 72-85. 
2 Van de Plassche, O. 1986: Sea-level research: a manual for the collection and evaluation of data. 618 3 pp. Geobooks, Norwich.

5 Van de Plassche, O. 1991: Coastal submergence of the Netherlands, NW Brittany (France), Delmarva

6 Peninsula (VA, USA) and Connecticut (USA) during the last 5500 to 7500 sidereal years. In Sabadini, 7 R. (ed.): Glacial isostasy, sea level and mantle rheology, 285-300. Kluwer, Dordrecht.

9 Van de Plassche, O. 1995: Evolution of the intra-coastal tidal range in the Rhine-Meuse delta and 10 Flevo Lagoon, 5700-3000 yrs cal B.C. Marine Geology 124, 113-128.

12 Van Geel, B., Buurman, J., Waterbolk, H.T. 1996: Archaeological and palaeoecological indications of 13 an abrupt climate change in the Netherlands, and evidence for climatological teleconnections around 142650 BP. Journal of Quaternary Science 11, 451-460.

15

16 Visset, L. \& Bernard, J. 2006: Evolution du littoral et du paysage, de la presqu'île de Rhuys à la rivière 17 d'Etel (Massif armoricain - France), du Néolithique au Moyen Âge. Revue d'archéométrie 30, 143 18156.

20 Visset, L., Sellier, D. \& L'Helgouach, J. 1995: Le paléoenvironnement de la région de Carnac. 21 Sondage dans le marais de Kerdual, La Trinité-sur-Mer (Morbihan). Revue Archéologique de l'Ouest $22 \quad 12,57-71$.

24 Wang, Y., Frank Bohlen, W. \& O'Donnell, J. 2000: Storm enhanced bottom shear stress and 25 associated sediment Entrainment in a moderate energetic estuary. Journal of Oceanography 56, 31126317. 
1

2

6

7

8

9

10

11

12

13

14

15

16

17

18

19

20

21

22

23

24

25

26

27

28

29

30

31

32

33

34

35

36

37

38

39

40

41

42

43

44

45

46

47

48

49

50

51

52

53

54

55

56

57

58

59

60
1 Watcham, E.P., Shennan, I. \& Barlow, N.L.M. 2013: Scale considerations in using diatoms as

2 indicators of sea level change: lessons from Alaska. Journal of Quaternary Science 28, 165-179.

3

4 Woodroffe, S.A. \& Long, A.J. 2009: Salt marshes as archives of recent relative sea level change in $5 \quad$ West Greenland. Quaternary Science Reviews 28, 1750-1761.

6

7 


\section{$1 \quad$ Figure captions}

2

3 Fig. 1. Location maps of studied areas. A. Location of coastal sites used to produce SLIPs from 4 previous sea-level data (see Table 5 for more details) along the coasts of Brittany (France). B. 5 Location of coastal sites studied in this paper (see Fig. 2 for more details).

7 Fig. 2. Position of drillings and cross-marsh transects. A. Bay of Tresseny. B. Tresseny salt-marshes.

8 C. Porzguen back-barrier salt-marsh (Bay of Brest). D. Lanveur salt-marsh (Bay of Brest). E. Troaon

9 back-barrier salt-marsh (Bay of Brest). F. Arun back-barrier salt-marsh (Bay of Brest). Dots indicate

10 position of gouge augered drillings. Squares indicate position of vibracores used for $\mathrm{AMS}{ }^{14} \mathrm{C}$ dating,

11 sedimentological and fossil foraminiferal analyses. White lines correspond to cross-marsh

12 foraminiferal transects along which training sets were collected.

14 Fig.3. Composition of foraminiferal assemblages from surface sediment samples along cross-marsh 15 transects in the Lanveur and Arun marshes (Bay of Brest) and in the Tresseny salt-marsh.

Fig.4. Observed versus predicted elevation and associated residuals determined by the 'all data' model WAPLS component two (A and B), the 'salt-marsh' model WAPLS component two (C and D), the 'pruned' salt-marsh model WAPLS component three (E and F). The modern samples collected along both Lanveur and Arun cross-marsh transects are distinguished and outliers are highlighted (see text 21 for details).

Fig.5. Observed versus predicted elevation (A) and associated residuals (B) determined by the 'Tresseny model' WAPLS component two.

Fig.6. Detailed stratigraphic cross-section through back-barrier salt-mashes in the Bay of Brest 27 (location of drillings is shown in Fig. 2). 
1 Fig.7. Sedimentology, fossil foraminiferal assemblages and palaeomarsh surface reconstructed 2 elevations. A. Reference Core P-C2 (Porzguen salt-marsh). B. Reference Core T-C2 (Troaon salt3 marsh). C. Reference Core A-C10 (Arun salt-marsh). D. Reference Core A-C14 (Arun salt-marsh).

4

5 Fig.8. Detailed stratigraphic sections of the inner part of the bay of Tresseny (location is shown in 6 Fig.1).

7

8 Fig.9. Sedimentology, fossil foraminiferal assemblages and transfer function reconstructions for 9 Reference Core G-C2 (Bay of Tresseny).

10

11 Fig. 10. Mid- to late Holocene RSL plots from the coasts of Brittany. A. SLIPs produced in this study 12 using FBTF reconstructions. SLIPs obtained from samples with 'poor' modern analogues are excluded. 13 Two SLIPs from the basal brackish peat of the Tresseny sediment sequence are also plotted. Numbers 14 correspond to radiocarbon dates presented in Table 2. Black line is the mean trend of RSL rise 15 calculated by a linear regression using the whole SLIPs. B. Plot of SLIPs available in Brittany (see 16 Table 5 for details). The RSL records from North-East, North-West and South-East parts of Brittany 17 are distinguished. Basal SLIPs providing reliable RSL data are highlighted.

\section{Table captions}

20
Table 1. Tide levels relative to French ordonance datum (m NGF) from SHOM 2013.

Table 2. Details of AMS ${ }^{14} \mathrm{C}$ dates obtained from drillings of the West Brittany salt-marshes. Calibrated age based on Intcal13 calibration curve (Reimer et al. 2013). Sea-Level index points (SLIPs) obtained from transfer function reconstructions.

Table 3. Transfer function model details. Numbers in bold are cited in the text. 
1 Table 4. Sedimentary facies and associated environments of the Western Brittany salt-marsh sediment 2 infillings.

3

4 Table 5. Re-assessment of previous sea-level records from Brittany.

5

6

\section{$7 \quad$ Supporting Information}

8

9 Table S1. Relative total (dead and alive) abundances of foraminifera taxa found within the modern 10 11

24 Table S6. Relative total (dead and alive) abundances of foraminifera taxa found within the samples 25 collected from the core G-C2 (Tresseny saltmarsh). 


\begin{tabular}{|c|c|c|c|c|c|c|c|c|}
\hline Study sites & $\begin{array}{c}\text { Lowest } \\
\text { astronomical } \\
\text { tide (LAT) }\end{array}$ & $\begin{array}{l}\text { Mean low water } \\
\text { spring tide } \\
\text { (MLWST) }\end{array}$ & $\begin{array}{c}\text { Mean low water } \\
\text { neap tide } \\
\text { (MLWNT) }\end{array}$ & $\begin{array}{l}\text { Mean tide } \\
\text { (MT) }\end{array}$ & $\begin{array}{c}\text { Mean high water } \\
\text { neap tide } \\
\text { (MHWNT) }\end{array}$ & $\begin{array}{l}\text { Mean high water } \\
\text { spring tide } \\
\text { (MHWST) }\end{array}$ & $\begin{array}{c}\text { Highest } \\
\text { astronomical } \\
\text { tide (HAT) }\end{array}$ & Tide gauge location \\
\hline Bay of Brest, Loc'h beach & -3.38 & -2.48 & -0.93 & 0.39 & 1.86 & 3.42 & 4.30 & Brest \\
\hline $\begin{array}{l}\text { Bay of Tresseny, Vougot beach, } \\
\text { Tariec beach }\end{array}$ & -3.95 & -3.02 & -1.27 & 0.39 & 2.03 & 3.68 & 4.45 & Aber Wrac'h \\
\hline Marais de Dol, Verger Bay & -6.684 & -5.124 & -2.224 & 0.426 & 3.126 & 6.276 & 7.746 & Cancale \\
\hline Ploudalmezeau beach & -3.725 & -2.855 & -1.155 & 0.465 & 2.045 & 3.645 & 4.505 & Portsall \\
\hline Kerminihy marsh & -1.545 & -1.135 & -0.485 & 0.515 & 1.465 & 2.265 & 2.855 & Etel \\
\hline Rohu-Pargo marsh & -2.719 & -1.949 & -0.699 & 0.431 & 1.551 & 2.651 & 3.171 & Port-Haliguen \\
\hline Kerdual marsh & -2.754 & -2.004 & -0.754 & 0.446 & 1.496 & 2.596 & 3.246 & Trinité-sur-Mer \\
\hline Suscinio marsh & -2.752 & -2.012 & -0.712 & 0.518 & 1.538 & 2.688 & 3.338 & Pénerf \\
\hline
\end{tabular}



in the core NGF) max. (med. prob.) min.

\begin{tabular}{lllllr}
\hline 1 & Erl-10678 & Porzguen marsh & P-C2 & $340-350$ & -0. \\
2 & Erl-10679 & Porzguen marsh & P-C2 & $410-420$ & -0.75 \\
3 & Er1-10680 & Porzguen marsh & P-C2 & $470-480$ & -1.3 \\
4 & Erl-10681 & Porzguen marsh & P-C2 & $500-510$ & -1. \\
5 & Erl-10682 & Troaon marsh & T-C2 & $60-70$ & +2. \\
6 & Erl-10683 & Troaon marsh & T-C2 & $340-350$ & 0.00 \\
7 & Erl-10684 & Troaon marsh & T-C2 & $370-380$ & -0.30
\end{tabular}
$-0.05 ;-0.15$ Halophytic plant remains $-0.75 ;-0.85$ Halophytic plant remains $-1.35 ;-1.45$ Halophytic plant remains $-1.65 ;-1.75$ Halophytic plant remains $0.00 ;-0.10 \quad$ Halophytic plant remains Erl-10684 Troaon marsh 9 Erl-10686 Troaon marsh

10 Erl-11753 Arun marsh

11 Erl-11749 Arun marsh

12 Erl-11750 Arun marsh

13 Erl-11751 Arun marsh

14 Erl-11752 Arun marsh

15 UBA 15681 Tresseny marsh

16 UBA 15682 Tresseny marsh

18 UBA 15684 Tresseny marsh

19 UBA 17893 Tresseny marsh

20 UBA 17894 Tresseny marsh

21 UBA 17895 Tresseny marsh

22 UBA 15685 Tresseny marsh

24 UBA 17897 Tresseny marsh

25 UBA 15686 Tresseny marsh

$\begin{array}{ll}\mathrm{T}-\mathrm{C} 2 & 370-380 \\ \mathrm{~T}-\mathrm{C} 2 & 470-480\end{array}$

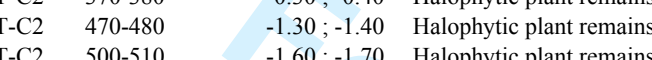

A-C10 $90-100$

A-C14 40-50

A-C14 140-150

A-C14 $270-280$

G-C2 $54-56$

G-C2 114-116

G-C2 154-156

G-C2 200-202

G-C2 284-286

G-C2 339-341

G-C2 369-371

G-C2 369-371

G-C2 $449-451$

G-C2 $494-496$ $-1.60 ;-1.70$ Halophytic plant remains $+3.10 ;+3.00$ Halogmen

Halophytic plant remains

$+2.10 ;+2.00$ Halophytic plant remain

$+0.80 ;+0.70$ wood fragmen

$+3.21 ;+3.19$ Halophytic plant remains $+2.61 ;+2.59$ Halophytic plant remain $+2.21,+2.19$ Halophytic plant remains $+1.75 ;+1.73$ Halophytic plant remain $+0.91 ;+0.89$ Halophytic plant remain $+0.36,+0.34$ Halophytic plant remains $+0.06 ;+0.04$ Halophytic plant remain .06 ; +0.04 Halophytic plant remain $-0.74 ;-0.72$ Halophytic plant remain

$3500 \pm 60 \quad-27.2$

3615 (3773) 3957

intercalated SLIP

\begin{tabular}{llll}
$4280 \pm 60$ & -27.4 & $4625(4852) 5036$ & intercalated SLIP \\
\hline
\end{tabular}

$\begin{array}{lll}4640 \pm 60 & -28.4 & 5071(5394) 5581 \\ 4775 \pm 60 & -28.6 & 5324(5509) 5605\end{array}$

$\begin{array}{lll}940 \pm 56 & -26.5 & 734(850) 952\end{array}$

$\begin{array}{lll}3690 \pm 70 & -28.3 & 3843(4031) 4235 \\ 4230 \pm 60 & -28.8 & 4569(4744) 4956\end{array}$

$\begin{array}{lll}4440 \pm 60 & -28.7 & 4872(5066) 5287 \\ 5450 \pm 70 & -28.1 & 6015(6242) 6399\end{array}$

$\begin{array}{rrr}5450 \pm 70 & -28.1 & 6015(6242) 6399 \\ 1081 \pm 56 & -24.1 & 916(999) 1174\end{array}$

$\begin{array}{ccc}1081 \pm 56 & -24.1 & 916(999) 1174 \\ 436 \pm 55 & -24.3 & 316(483) 546 \\ 1686+56 & -25.8 & 1415(1597) 1720\end{array}$

$1686 \pm 56 \quad-25.8$

$\begin{array}{llll}2340 \pm 54 & -26.6 & 2159(2372) 2691 & \text { intercalated SLIP }\end{array}$

$\begin{array}{llll}2716 \pm 55 & -27.2 & 2748(2822) 2941 & \text { basal SLIP }\end{array}$

$\begin{array}{cccc}431 \pm 28 & -28.5 & 338(500) 527 & \text { intec } \\ 1819 \pm 28 & -28.4 & 1825(1761) 1631 & \mathrm{n} / \mathrm{a}\end{array}$

$\begin{array}{llll}1819 \pm 28 & -28.4 & 1825(1761) 1631 & \mathrm{n} / \mathrm{a} \\ 2522 \pm 32 & -27.6 & 2744(2597) 2490 & \mathrm{n} / \mathrm{a}\end{array}$

$\begin{array}{llll}2522 \pm 32 & -27.6 & 2744(2597) 2490 & \mathrm{n} / \mathrm{a} \\ 2732 \pm 36 & -25.7 & 2921(2824) 2758 & \mathrm{n} /\end{array}$

$2657 \pm 22 \quad-25.8 \quad 2836(2764) 2745 \quad \mathrm{n} / \mathrm{a}$

$\begin{array}{llll}2690 \pm 27 & -26.0 & 2846(2788) 2755 & \mathrm{n} / \mathrm{a}\end{array}$

$\begin{array}{llll}2689 \pm 22 & -28.3 & 2844(2783) 2755 & \mathrm{n} / \mathrm{a}\end{array}$

$\begin{array}{llll}2666 \pm 25 & -27.1 & 2844(2770) 2746 & \mathrm{n} / \mathrm{a} \\ 4148 \pm 34 & -28.1 & 4826(4692) 4572 & \mathrm{n} / \mathrm{a}\end{array}$

$\begin{array}{llll}4148 \pm 34 & -28.1 & 4826(4692) 4572 & \mathrm{n} / \mathrm{a} \\ 4795 \pm 24 & -24.7 & 5592(5513) 5474 & \mathrm{n} / \mathrm{a}\end{array}$

$\begin{array}{llll}5563 \pm 31 & -28.8 & 6299(6351) 6403 & \text { Basal }\end{array}$ $-0.89 ;-0.91 \quad$ Detrital Phragmites

$4426(4530) 478$

\begin{tabular}{|c|c|c|c|}
\hline & & & \\
\hline & & & elevation \\
\hline 'close' analogues & -4.17 & \pm 0.05 & \pm 0.13 \\
\hline 'close' analogues & -5.32 & \pm 0.05 & \pm 0.13 \\
\hline 'poor' analogues & $\mathrm{n} / \mathrm{a}$ & \pm 0.05 & \pm 0.13 \\
\hline 'close' analogues & -0.48 & \pm 0.05 & \pm 0.13 \\
\hline 'close' analogues & -3.35 & \pm 0.05 & \pm 0.13 \\
\hline 'poor' analogues & $\mathrm{n} / \mathrm{a}$ & \pm 0.05 & \pm 0.13 \\
\hline 'poor' analogues & $\mathrm{n} / \mathrm{a}$ & \pm 0.05 & \pm 0.13 \\
\hline 'close' analogues & -5.32 & \pm 0.05 & \pm 0.13 \\
\hline 'close' analogues & -0.61 & \pm 0.05 & \pm 0.13 \\
\hline 'close' analogues & -0.30 & \pm 0.05 & \pm 0.13 \\
\hline 'close' analogues & -0.97 & \pm 0.05 & \pm 0.13 \\
\hline 'good' analogues & -2.26 & \pm 0.05 & \pm 0.13 \\
\hline 'close' analogues & -2.96 & \pm 0.05 & \pm 0.13 \\
\hline 'good' analogues & -0.28 & \pm 0.025 & \pm 0.13 \\
\hline $\mathrm{n} / \mathrm{a}$ & $\mathrm{n} / \mathrm{a}$ & \pm 0.01 & \pm 0.13 \\
\hline $\mathrm{n} / \mathrm{a}$ & $\mathrm{n} / \mathrm{a}$ & \pm 0.01 & \pm 0.13 \\
\hline $\mathrm{n} / \mathrm{a}$ & $\mathrm{n} / \mathrm{a}$ & \pm 0.01 & \pm 0.13 \\
\hline $\mathrm{n} / \mathrm{a}$ & $\mathrm{n} / \mathrm{a}$ & \pm 0.01 & \pm 0.13 \\
\hline $\mathrm{n} / \mathrm{a}$ & $\mathrm{n} / \mathrm{a}$ & \pm 0.01 & \pm 0.13 \\
\hline $\mathrm{n} / \mathrm{a}$ & $\mathrm{n} / \mathrm{a}$ & \pm 0.01 & \pm 0.13 \\
\hline $\mathrm{n} / \mathrm{a}$ & $\mathrm{n} / \mathrm{a}$ & \pm 0.01 & \pm 0.13 \\
\hline $\mathrm{n} / \mathrm{a}$ & $\mathrm{n} / \mathrm{a}$ & \pm 0.01 & \pm 0.13 \\
\hline $\mathrm{n} / \mathrm{a}$ & $\mathrm{n} / \mathrm{a}$ & \pm 0.01 & \pm 0.13 \\
\hline $\mathrm{n} / \mathrm{a}$ & -4.97 & \pm 0.01 & \pm 0.13 \\
\hline & -3.75 & \pm 0.01 & \pm 0.13 \\
\hline
\end{tabular}


\begin{tabular}{lll}
\hline \multicolumn{2}{c}{ Vertical error $(\mathrm{m})$} \\
\hline RMSEP Modern analogue & Total (with $2 \sigma)$
\end{tabular}

\begin{tabular}{lcl}
\hline $\begin{array}{l}\text { RMSEP } \\
\text { RMSEP 2 } \sigma)\end{array}$ & $\begin{array}{c}\text { Modern analogue } \\
\text { sampling }\end{array}$ & Total (with 2 $\sigma$ ) \\
\hline $\pm 0.20(0.39)$ & \pm 0.10 & $\pm 0.48(0.67)$ \\
& & $\pm 0.48(0.67)$
\end{tabular}

$\begin{array}{lll} \pm 0.20(0.39) & \pm 0.10 & \pm 0.48(0.67) \\ \pm 0.20(0.39) & \pm 0.10 & \pm 0.48(0.67)\end{array}$

$\begin{array}{lll} \pm 0.20(0.39) & \pm 0.10 & \pm 0.48(0.67)\end{array}$

$\begin{array}{lll}0.20(0.39) & \pm 0.10 & \pm 0.48(0.67)\end{array}$

$\begin{array}{lll} \pm 0.20(0.39) & \pm 0.10 \quad \pm 0.48(0.67)\end{array}$

$\pm 0.20(0.39) \quad \pm 0.10 \quad \pm 0.48(0.67)$

$\pm 0.20(0.39) \quad \pm 0.10 \quad \pm 0.48(0.67)$

$\pm 0.20(0.39) \quad \pm 0.10 \quad \pm 0.48(0.67)$

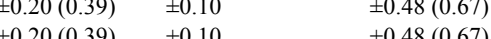

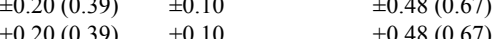

$\pm 0.20(0.39) \quad \pm 0.10 \quad \pm 0.48(0.67)$

$\begin{array}{lll}0.20(0.39) & \pm 0.10 & \pm 0.48(0.67)\end{array}$

$\pm 0.20(0.39) \quad \pm 0.10 \quad \pm 0.48(0.67)$

$\pm 0.14(0.27) \quad \pm 0.10 \quad \pm 0.39(0.55)$

$\mathrm{n} / \mathrm{a} \quad \mathrm{n} / \mathrm{a} / \mathrm{a}$

$\mathrm{n} / \mathrm{a} \quad \mathrm{n} / \mathrm{a} \quad \mathrm{n} / \mathrm{a}$

$\begin{array}{lll}\mathrm{n} / \mathrm{a} & \mathrm{n} / \mathrm{a} & \mathrm{n} / \mathrm{a} \\ \mathrm{n} / \mathrm{a} & \mathrm{n} / \mathrm{a} & \mathrm{n} / \mathrm{a}\end{array}$

$\mathrm{n} / \mathrm{a} \quad \mathrm{n} / \mathrm{a} \quad \mathrm{n} / \mathrm{a}$

$\mathrm{n} / \mathrm{a} \quad \mathrm{n} / \mathrm{a} \quad \mathrm{n} / \mathrm{a}$

$\begin{array}{lll}\mathrm{n} / \mathrm{a} & \mathrm{n} / \mathrm{a} & \mathrm{n} / \mathrm{a} \\ \mathrm{n} / \mathrm{a} & \mathrm{n} / \mathrm{a} & \mathrm{n} / \mathrm{a}\end{array}$

\begin{tabular}{lll}
$\mathrm{n} / \mathrm{a}$ & $\mathrm{n} / \mathrm{a}$ & $\mathrm{n} / \mathrm{a}$ \\
$\mathrm{n} / \mathrm{a}$ & $\mathrm{n} / \mathrm{a}$ & $\mathrm{n} / \mathrm{a}$ \\
$\mathrm{n} / \mathrm{a}$ & $\mathrm{n} / \mathrm{a}$ & \pm 1.35 \\
\hline
\end{tabular}

\begin{tabular}{lll}
$\mathrm{n} / \mathrm{a}$ & $\mathrm{n} / \mathrm{a}$ & \pm 1.35 \\
\hline
\end{tabular}

27

28

29

30

31

32

33

34

35

36

37

38

39

40

41

42

43

44

45

46

47

48

10 


\section{Page 43 of 68}

Boreas

\begin{tabular}{|c|c|c|c|c|c|c|}
\hline \multirow[t]{2}{*}{ Model description } & \multirow{2}{*}{$\begin{array}{l}\text { Performance } \\
\text { index }\end{array}$} & \multicolumn{5}{|c|}{ Components } \\
\hline & & $\mathrm{C} 1$ & $\mathrm{C} 2$ & $\mathrm{C} 3$ & $\mathrm{C} 4$ & C5 \\
\hline Bay of Tresseny & RMSE (m) & 0.19 & 0.12 & 0.11 & 0.10 & 0.10 \\
\hline Tresseny model- WAPLS (DDCA length: 3.540; DDCA stand.dev: 0.4546) & $\mathrm{r}^{2}$ & 0.82 & 0.93 & 0.95 & 0.95 & 0.95 \\
\hline The whole training set used (14 species. 26 samples) & Max Bias (m) & 0.24 & 0.20 & 0.12 & 0.10 & 0.07 \\
\hline \multirow[t]{4}{*}{ Elevation range: $1.61 \mathrm{~m}$} & $\mathrm{r}^{2} \mathrm{jack}$ & 0.78 & 0.90 & 0.90 & 0.86 & 0.83 \\
\hline & Max Biasjack (m) & 0.26 & 0.25 & 0.19 & 0.24 & 0.30 \\
\hline & RMSEPjack (m) & 0.21 & 0.14 & 0.14 & 0.17 & 0.19 \\
\hline & & $\mathrm{C} 1$ & $\mathrm{C} 2$ & $\mathrm{C} 3$ & $\mathrm{C} 4$ & $\mathrm{C} 5$ \\
\hline Bay of Brest & RMSE (m) & 0.51 & 0.44 & 0.41 & 0.40 & 0.40 \\
\hline 1-'all data' model- WAPLS (DDCA length: 2.515; DDCA stand.dev: 0.9889 ) & $\mathrm{r}^{2}$ & 0.73 & 0.80 & 0.83 & 0.84 & 0.84 \\
\hline The whole training set used ( 14 species. 51 samples) & Max Bias (m) & 1.12 & 0.70 & 0.64 & 0.59 & 0.61 \\
\hline \multirow[t]{3}{*}{ Elevation range: $3.27 \mathrm{~m}$} & $\mathrm{r}^{2} \mathrm{jack}$ & 0.71 & 0.76 & 0.76 & 0.75 & 0.76 \\
\hline & Max Biasjack (m) & 1.21 & 0.76 & 0.70 & 0.71 & 0.70 \\
\hline & RMSEPjack (m) & 0.53 & 0.48 & 0.49 & 0.49 & 0.49 \\
\hline & & $\mathrm{C} 1$ & $\mathrm{C} 2$ & $\mathrm{C} 3$ & $\mathrm{C} 4$ & $\mathrm{C} 5$ \\
\hline Bay of Brest & RMSE (m) & 0.43 & 0.37 & 0.36 & 0.35 & 0.34 \\
\hline 2-'salt-marsh' model- WAPLS & $r^{2}$ & 0.54 & 0.65 & 0.68 & 0.70 & 0.71 \\
\hline Samples from tidal-flat removed. training set of 9 species. 43 samples & $\operatorname{Max} \operatorname{Bias}(\mathrm{m})$ & 0.72 & 0.62 & 0.50 & 0.51 & 0.48 \\
\hline \multirow[t]{4}{*}{ Elevation range: $2.58 \mathrm{~m}$} & $r^{2}$ jack & 0.45 & 0.46 & 0.45 & 0.44 & 0.45 \\
\hline & Max Biasjack (m) & 0.75 & 0.69 & 0.58 & 0.98 & 1.12 \\
\hline & RMSEPjack (m) & 0.47 & 0.50 & 0.54 & 0.60 & 0.61 \\
\hline & & $\mathrm{C} 1$ & $\mathrm{C} 2$ & $\mathrm{C} 3$ & $\mathrm{C} 4$ & $\mathrm{C} 5$ \\
\hline \multicolumn{7}{|l|}{ Bay of Brest } \\
\hline 3 - 'pruned' salt-marsh model- WAPLS (DDCA length: 2.551; DDCA stand.dev: 0.9154) & RMSE (m) & 0.37 & 0.21 & 0.17 & 0.16 & 0.16 \\
\hline Samples from tidal-flat. tidal-creeks and salt-pans removed. & $\mathrm{r}^{2}$ & 0.68 & 0.90 & 0.94 & 0.94 & 0.94 \\
\hline Training set of 8 species. 29 samples & Max Bias (m) & 0.63 & 0.40 & 0.27 & 0.29 & 0.31 \\
\hline \multirow[t]{3}{*}{ Elevation range: $2.35 \mathrm{~m}$} & $r^{2} j a c k$ & 0.56 & 0.86 & 0.91 & 0.90 & 0.87 \\
\hline & Max Biasjack (m) & 0.94 & 0.48 & 0.30 & 0.33 & 0.39 \\
\hline & RMSEPjack (m) & 0.44 & 0.25 & 0.20 & 0.22 & 0.26 \\
\hline
\end{tabular}


2

\begin{tabular}{|c|c|c|}
\hline Lithofacies & Description & Mean grain size \\
\hline LF1 & Reed peat with phragmites remains & $30-60 \mu \mathrm{m}$ \\
\hline LF2 & $\begin{array}{l}\text { Silty clay with salt-marsh plant fragments } \\
\text { and rootlets }\end{array}$ & $20-60 \mu \mathrm{m}$ \\
\hline LF3 & Silty-sand with shell fragments & $100 \mu \mathrm{m}$ \\
\hline LF4 & $\begin{array}{l}\text { Grey silty-clay mm-laminated with black } \\
\text { organic-rich silt }\end{array}$ & $50-60 \mu \mathrm{m}$ \\
\hline LF5 & Coarse sand and gravels & $800-1200 \mu \mathrm{m}$ \\
\hline LF6 & $\begin{array}{l}\text { Reed peat with phragmites remains and a } \\
\text { significant proportion of sand }\end{array}$ & $150-250 \mu \mathrm{m}$ \\
\hline LF7 & Coarse sand & $800-1000 \mu \mathrm{m}$ \\
\hline LF8 & Minerogenic sandy-silt & $100 \mu \mathrm{m}$ \\
\hline LF9 & Sandy-silt with rootlets and plants debris & $50-250 \mu \mathrm{m}$ \\
\hline
\end{tabular}


2

\begin{tabular}{ll}
\hline Foraminiferal content & Depositional environment \\
\hline $\begin{array}{l}\text { Occasional presence of high salt-marsh } \\
\text { agglutinated foraminifera dominant }\end{array}$ & Brackish marsh to swamp \\
$\begin{array}{l}\text { High salt-marsh agglutinated foraminifera } \\
\text { Salt-marsh agglutinated and calcareous }\end{array}$ & High salt-marsh \\
$\begin{array}{l}\text { foraminifera } \\
\text { High salt-marsh agglutinated foraminifera, } \\
\text { occasional absence of foraminifera }\end{array}$ & Back-barrier brackish marsh to freshwater swamp \\
$\begin{array}{ll}\text { No foraminifera } \\
\text { Very low foraminiferal density }\end{array}$ & $\begin{array}{l}\text { Gravel barrier washover fan } \\
\text { input }\end{array}$ \\
$\begin{array}{ll}\text { No foraminifera } \\
\text { Very low foraminiferal density }\end{array}$ & Sand-flat or breach in the barrier dune \\
High salt-marsh agglutinated foraminifera & High salt-marsh \\
\hline
\end{tabular}




\begin{tabular}{|c|c|c|c|c|}
\hline No & Lab. code & Coastal site & Elevation (m NGF) & Material \\
\hline$\overline{1}$ & GrN-14138 & Marais de Dol & $-2.41 ;-2.45$ & reed peat \\
\hline 2 & GrN-14139 & Marais de Dol & $+0.90 ;+0.94$ & reed peat \\
\hline 3 & GrN-14140 & Marais de Dol & $+1.48 ;+1.51$ & reed peat + peaty jyttja \\
\hline 4 & GrN-14141 & Marais de Dol & $+2.03 ;+2.05$ & amorphous peat \\
\hline 5 & GrN-14142 & Marais de Dol & $+0.65 ;+0.69$ & reed peat \\
\hline 6 & GrN-14143 & Marais de Dol & $+0.87 ;+0.91$ & reed peat \\
\hline 7 & GrN-14144 & Marais de Dol & $+1.14 ;+1.17$ & reed peat \\
\hline 8 & GrN-14145 & Marais de Dol & $-2.71 ;-2.77$ & peaty jyttja + reed remains \\
\hline 9 & GrN-14146 & Marais de Dol & $+1.53 ;+1.56$ & oxidized reed peat \\
\hline 10 & GrN-14147 & Marais de Dol & $+1.83 ;+1.87$ & reed peat + leaf remains \\
\hline 11 & GrN-14148 & Marais de Dol & $+6.23 ;+6.28$ & reed peat \\
\hline 12 & GrN-14149 & Marais de Dol & $+0.52 ;+0.56$ & peaty clay + reed remains \\
\hline 13 & GrN-14150 & Marais de Dol & $+1.80 ;+1.83$ & reed peat \\
\hline 14 & GrN-14151 & Marais de Dol & $+3.05 ;+3.08$ & reed peat \\
\hline 15 & GrN-14152 & Marais de Dol & $+3.14 ;+3.17$ & humic clay + vegetation remains \\
\hline 16 & GrN-14153 & Marais de Dol & $+3.32 ;+3.35$ & oxidized reedpeat + wood remains \\
\hline 17 & GrN-14154 & Marais de Dol & $+1.90 ;+1.94$ & oxidized reedpeat \\
\hline 18 & GrN-14155 & Marais de Dol & $+2.15 ;+2.17$ & oxidized peat \\
\hline 19 & GrN-14156 & Marais de Dol & $+1.75 ;+1.79$ & oxidized peat \\
\hline 20 & GrN-14157 & Marais de Dol & $+2.12 ;+2.15$ & oxidized peat \\
\hline 21 & GrN-14158 & Marais de Dol & $-0.26 ;-0.30$ & reed peat \\
\hline 22 & GrN-14159 & Marais de Dol & $+1.48 ;+1.51$ & peaty clay \\
\hline 23 & GrN-14160 & Marais de Dol & $+2.05 ;+2.09$ & reed peat \\
\hline 24 & GrN-14161 & Marais de Dol & $+2.30 ;+2.34$ & reed peat \\
\hline 25 & * & Verger bay & $-8.10 ;-9.10$ & Silty-clay + halophitic plant remains \\
\hline 26 & $*$ & Verger bay & $+2.50 ;+1.50$ & Silty-clay + halophitic plant remains \\
\hline 27 & * & Verger bay & $+2.50 ;+1.50$ & Organic-rich mud \\
\hline 28 & UBA-15461 & Vougot beach & $-1.14 ;-1.16$ & Detrital Phragmites \\
\hline 29 & UBA-15460 & Vougot beach & $-3.51 ;-3.53$ & Detrital Phragmites \\
\hline 30 & UBA-15458 & Tariec beach & $-3.79 ;-3.81$ & Detrital Phragmites \\
\hline 31 & Gif-766 & Ploudalmezeau beach & -4.40 & reed peat \\
\hline 32 & Ly-8871 & Loc'h beach & +1.64 & Wood fragment within organic mud \\
\hline 33 & Ly-8870 & Loc'h beach & +2.15 & Wood fragment within organic mud \\
\hline 34 & A10101 & Kerminihy marsh & +0.79 & reed peat \\
\hline 35 & Ly-11481 & Rohu-Pargo marsh & +2.43 & Silty-clay + halophitic plant remains \\
\hline 36 & Beta-185617 & Rohu-Pargo marsh & +1.15 & Silty-clay + halophitic plant remains \\
\hline 37 & Ly-11482 & Rohu-Pargo marsh & +0.53 & Silty-clay + halophitic plant remains \\
\hline 38 & Ly6001 & Kerdual marsh & +0.82 & Silty-clay + halophitic plant remains \\
\hline 39 & Ly6002 & Kerdual marsh & +0.27 & Silty-clay + halophitic plant remains \\
\hline 40 & A9830 & Suscinio marsh & -1.57 & Silty-clay + halophitic plant remains \\
\hline 41 & A9832 & Suscinio marsh & -2.77 & Silty-clay + halophitic plant remains \\
\hline 42 & A9829 & Suscinio marsh & -3.37 & Silty-clay + halophitic plant remains \\
\hline 43 & A9831 & Suscinio marsh & -4.15 & Silty-clay + halophitic plant remains \\
\hline 44 & A9833 & Suscinio marsh & -4.87 & Silty-clay + halophitic plant remains \\
\hline
\end{tabular}




\begin{tabular}{|c|c|c|c|c|c|c|}
\hline Indicative meaning & $\begin{array}{l}\text { Indicative } \\
\text { range }(\mathrm{m})\end{array}$ & ${ }^{14} \mathrm{Ca} \pm 1 \sigma$ & $\begin{array}{c}\text { Cal. a BP }(2 \sigma) \\
\text { max. (med. prob.) min. }\end{array}$ & RSL (m) & $\begin{array}{l}\text { Error range } \\
\text { (m) }\end{array}$ & type of SLIP \\
\hline from MHWNT to HAT & \pm 2.31 & $6625 \pm 35$ & $7572(7515) 7439$ & -10.18 & \pm 2.8 & intercalated SLIP \\
\hline om MHWNT to HAT & \pm 2.31 & $5980 \pm 60$ & $6955(6820) 6669$ & -6.83 & \pm 2.8 & intercalated SLIP \\
\hline om MHWNT to HAT & \pm 2.31 & $5800 \pm 45$ & $6726(6600) 6491$ & -6.25 & \pm 2.8 & intercalated SLIP \\
\hline from MHWNT to HAT & \pm 2.31 & $5450 \pm 35$ & $6302(6247) 6193$ & -5.71 & \pm 2.8 & intercalated SLIP \\
\hline from MHWNT to HAT & \pm 2.31 & $6075 \pm 45$ & 7155 (6937) 6792 & -7.08 & \pm 2.8 & intercalated SLIP \\
\hline from MHWNT to HAT & \pm 2.31 & $5820 \pm 40$ & $6730(6628) 6503$ & -6.86 & \pm 2.8 & intercalated SLIP \\
\hline from MHWNT to HAT & \pm 2.31 & $5425 \pm 40$ & $6302(6237) 6034$ & -6.6 & \pm 2.8 & intercalated SLIP \\
\hline rom MHWNT to HAT & \pm 2.31 & $6540 \pm 70$ & 7569 (7454) 7320 & -10.49 & \pm 2.8 & intercalated SLIP \\
\hline from MHWNT to HAT & \pm 2.31 & $5295 \pm 35$ & $6185(6081) 5948$ & -6.2 & \pm 2.8 & intercalated SLIP \\
\hline from MHWNT to HAT & \pm 2.31 & $4835 \pm 35$ & $5645(5585) 5476$ & -5.9 & \pm 2.8 & intercalated SLIP \\
\hline from MHWNT to HAT & \pm 2.31 & $2820 \pm 30$ & 3016 (2922) 2847 & -1.5 & \pm 2.8 & intercalated SLIP \\
\hline from MHWNT to HAT & \pm 2.31 & $6070 \pm 45$ & 7155 (6929) 6789 & -7.21 & \pm 2.8 & intercalated SLIP \\
\hline from MHWNT to HAT & \pm 2.31 & $5365 \pm 35$ & $6277(6167) 6004$ & -5.93 & \pm 2.8 & intercalated SLIP \\
\hline from MHWNT to HAT & \pm 2.31 & $4730 \pm 60$ & 5587 (5469) 5321 & -4.68 & \pm 2.8 & intercalated SLIP \\
\hline from MHWNT to HAT & \pm 2.31 & $4385 \pm 40$ & 5213 (4948) 4851 & -4.6 & \pm 2.8 & intercalated SLIP \\
\hline from MHWNT to HAT & \pm 2.31 & $4340 \pm 35$ & $5030(4910) 4842$ & -4.41 & \pm 2.8 & intercalated SLIP \\
\hline from MHWNT to HAT & \pm 2.31 & $5535 \pm 30$ & 6398 (6334) 6288 & -5.83 & \pm 2.8 & intercalated SLIP \\
\hline from MHWNT to HAT & \pm 2.31 & $5030 \pm 35$ & $5895(5807) 5662$ & -5.59 & \pm 2.8 & intercalated SLIP \\
\hline from MHWNT to HAT & \pm 2.31 & $4870 \pm 35$ & $5661(5610) 5486$ & -5.98 & \pm 2.8 & intercalated SLIP \\
\hline from MHWNT to HAT & \pm 2.31 & $4430 \pm 35$ & $5277(5021) 4873$ & -5.62 & \pm 2.8 & intercalated SLIP \\
\hline from MHWNT to HAT & \pm 2.31 & $5725 \pm 40$ & $6635(6521) 6414$ & -8.03 & \pm 2.8 & intercalated SLIP \\
\hline from MHWNT to HAT & \pm 2.31 & $5760 \pm 60$ & $6712(6560) 6409$ & -6.26 & \pm 2.8 & intercalated SLIP \\
\hline from MHWNT to HAT & \pm 2.31 & $5305 \pm 35$ & $6190(6085) 5951$ & -5.68 & \pm 2.8 & intercalated SLIP \\
\hline from MHWNT to HAT & \pm 2.31 & $4960 \pm 35$ & $5842(5686) 5603$ & -5.43 & \pm 2.8 & intercalated SLIP \\
\hline from MHWNT to HAT & \pm 2.31 & $7310 \pm 80$ & 7977 (8120) 8314 & -13.74 & \pm 2.8 & Basal SLIP \\
\hline from MHWNT to HAT & \pm 2.31 & $2630 \pm 130$ & $2353(2727) 3005$ & -1.36 & \pm 2.8 & Basal SLIP \\
\hline from MHWNT to HAT & \pm 2.31 & $4020 \pm 130$ & $4152(4508) 4839$ & -3.136 & \pm 2.8 & Basal SLIP \\
\hline from MHWNT to HAT & \pm 1.21 & $4309 \pm 38$ & $4970(4900) 4830$ & -4.39 & \pm 1.3 & Basal SLIP \\
\hline from MHWNT to HAT & \pm 1.21 & $6033 \pm 29$ & $6950(6870) 6790$ & -6.74 & \pm 1.3 & Basal SLIP \\
\hline from MHWNT to HAT & \pm 1.21 & $6001 \pm 28$ & $6910(6850) 6780$ & -6.78 & \pm 1.3 & Basal SLIP \\
\hline from MHWNT to HAT & \pm 1.23 & $5770 \pm 150$ & $6933(6610) 6288$ & -7.26 & \pm 1.7 & intercalated SLIP \\
\hline from MHWNT to HAT & \pm 1.22 & $1075 \pm 40$ & $927(985) 1061$ & -1.437 & \pm 1.3 & intercalated SLIP \\
\hline from MHWNT to HAT & \pm 1.22 & $950 \pm 25$ & $796(853) 925$ & -0.926 & \pm 1.3 & intercalated SLIP \\
\hline from MHWNT to HAT & \pm 0.695 & $2535 \pm 65$ & 2379 (2596) 2757 & -1.37 & \pm 0.8 & intercalated SLIP \\
\hline from MHWNT to HAT & \pm 0.81 & $1190 \pm 50$ & $981(1118) 1258$ & 0.069 & \pm 2 & intercalated SLIP \\
\hline from MHWNT to HAT & \pm 0.81 & $2810 \pm 40$ & 2792 (2913) 3031 & -1.211 & \pm 1 & intercalated SLIP \\
\hline from MHWNT to HAT & \pm 0.81 & $3570 \pm 35$ & $3726(3871) 3975$ & -1.831 & \pm 0 & intercalated SLIP \\
\hline from MHWNT to HAT & \pm 0.875 & $2905 \pm 55$ & $2880(3045) 3207$ & -1.551 & \pm 1 & intercalated SLIP \\
\hline from MHWNT to HAT & \pm 0.875 & $3155 \pm 85$ & $3161(3370) 3573$ & -2.101 & \pm 1 & intercalated SLIP \\
\hline from MHWNT to HAT & \pm 0.9 & $4895 \pm 70$ & $5471(5638) 5881$ & -4.008 & \pm 1 & intercalated SLIP \\
\hline from MHWNT to HAT & \pm 0.9 & $5590 \pm 90$ & $6211(6384) 6626$ & -5.208 & \pm 1 & intercalated SLIP \\
\hline from MHWNT to HAT & \pm 0.9 & $5700 \pm 115$ & $6287(6502) 6742$ & -5.808 & \pm 1 & intercalated SLIP \\
\hline from MHWNT to HAT & \pm 0.9 & $5700 \pm 80$ & $6316(6496) 6660$ & -6.588 & \pm 1 & intercalated SLIP \\
\hline from MHWNT to HAT & \pm 0.9 & $6600 \pm 85$ & $7325(7497) 7617$ & -7.308 & \pm 1 & Basal SLIP \\
\hline
\end{tabular}


Reference

Van de Plassche (1991)

Van de Plassche (1991)

Van de Plassche (1991)

Van de Plassche (1991)

Van de Plassche (1991)

Van de Plassche (1991)

Van de Plassche (1991)

Van de Plassche (1991)

Van de Plassche (1991)

Van de Plassche (1991)

Van de Plassche (1991)

Van de Plassche (1991)

Van de Plassche (1991)

Van de Plassche (1991)

Van de Plassche (1991)

Van de Plassche (1991)

Van de Plassche (1991)

Van de Plassche (1991)

Van de Plassche (1991)

Van de Plassche (1991)

Van de Plassche (1991)

Van de Plassche (1991)

Van de Plassche (1991)

Van de Plassche (1991)

Regnauld et al. (1996)

Regnauld et al. (1996)

Regnauld et al. (1996)

Goslin et al . (2013)

Goslin et al . (2013)

Goslin et al . (2013)

Morzadec-Kerfourn (1969)

Stéphan \& Laforge (2013)

Stéphan \& Laforge (2013)

Visset \& Bernard (2006)

Gaudin (2004)

Gaudin (2004)

Gaudin (2004)

Visset et al. (1995)

Visset et al. (1995)

Visset \& Bernard (2006)

Visset \& Bernard (2006)

Visset \& Bernard (2006)

Visset \& Bernard (2006)

Visset \& Bernard (2006) 


\section{Page 49 of 68}

\section{Boreas}

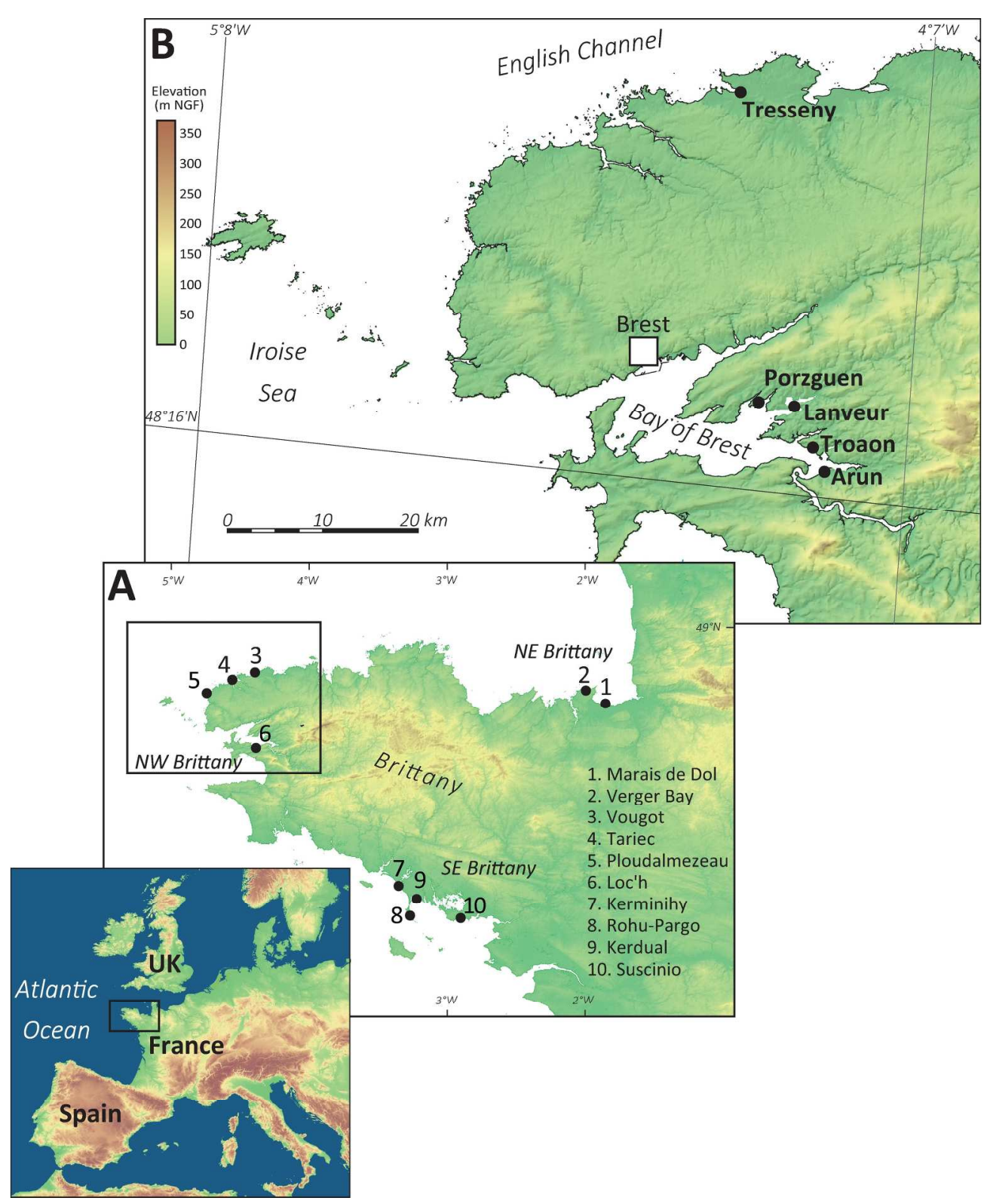

$210 \times 255 \mathrm{~mm}(300 \times 300$ DPI $)$ 


\section{Boreas}

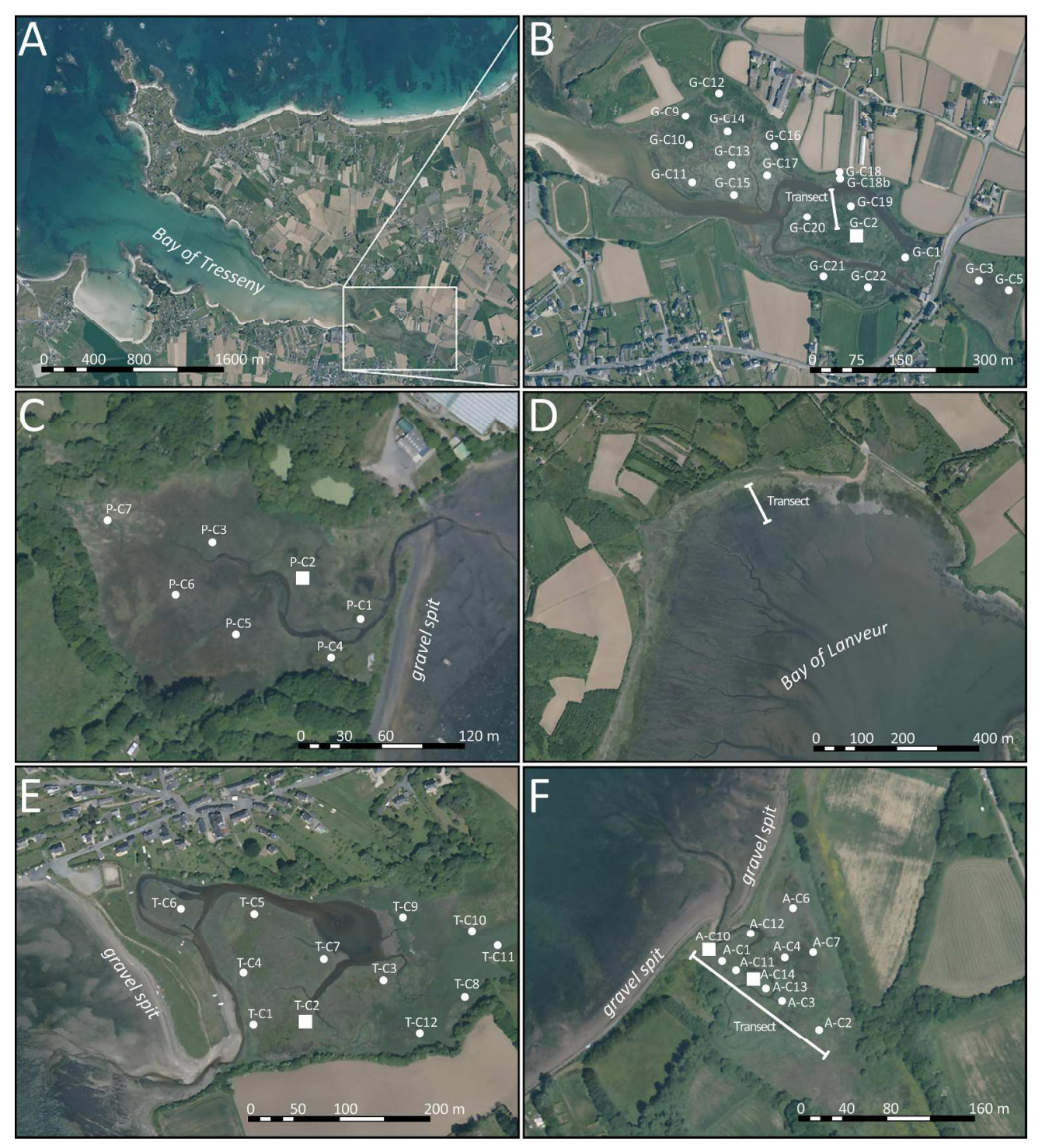

$219 \times 244 \mathrm{~mm}(300 \times 300 \mathrm{DPI})$ 

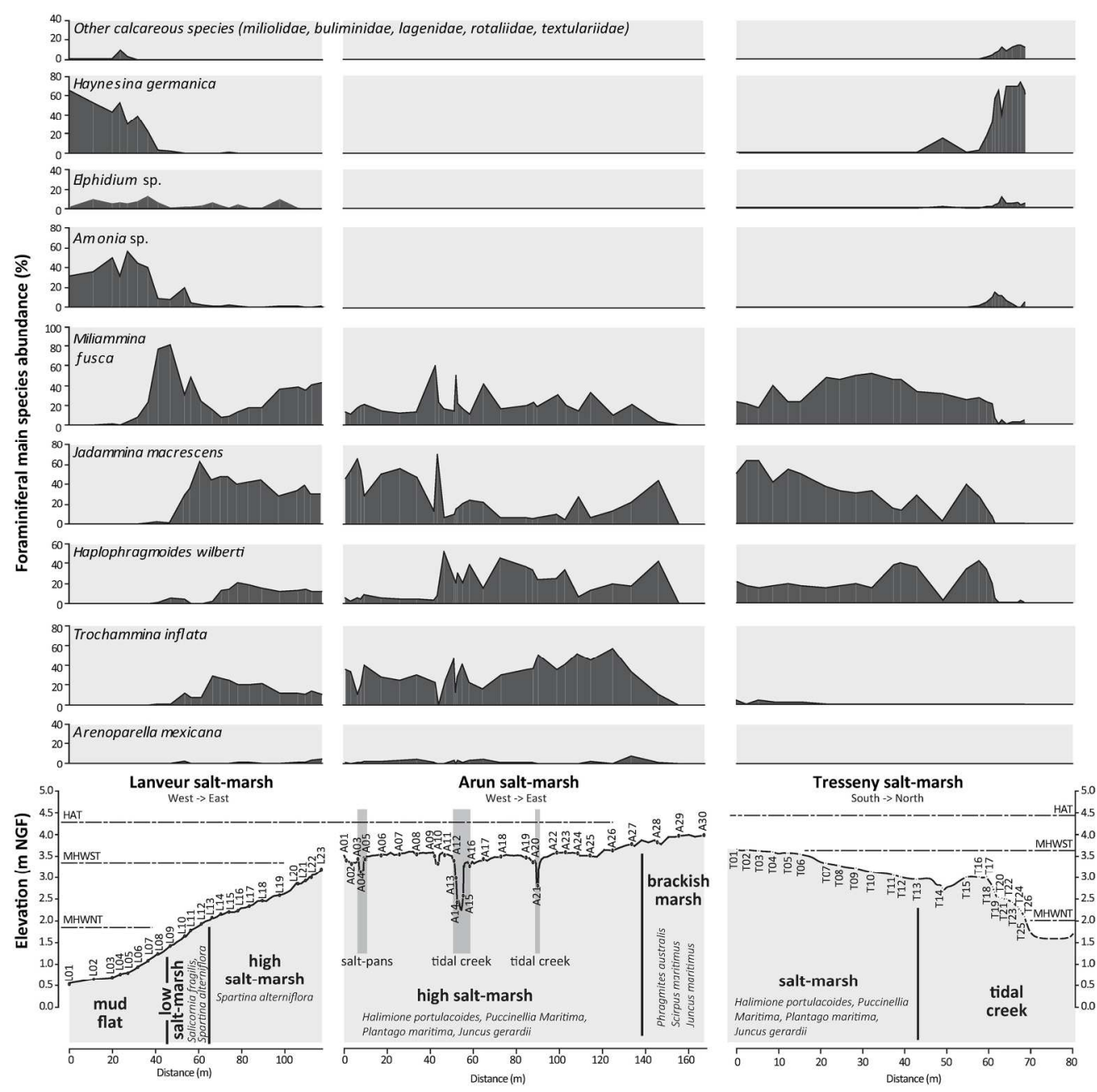

$187 \times 185 \mathrm{~mm}(300 \times 300 \mathrm{DPI})$ 
1-'all data' model
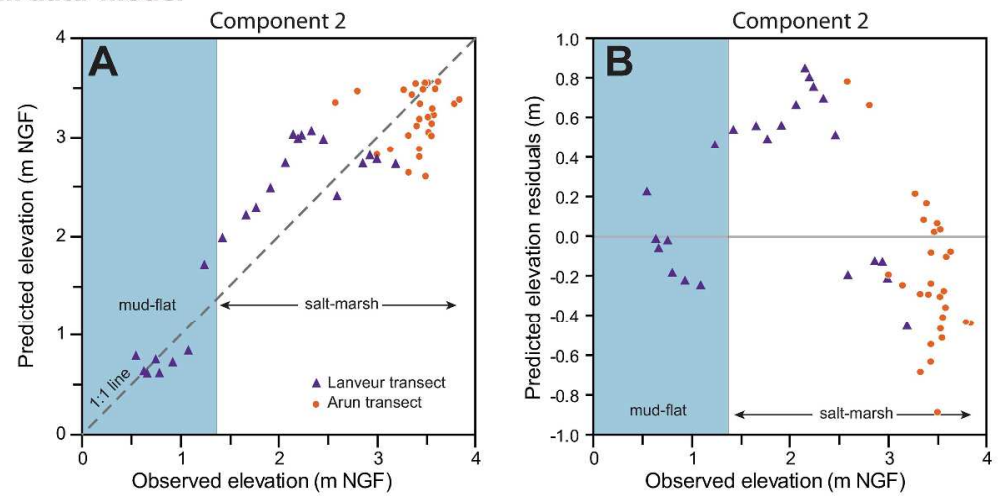

2- 'salt-marsh' model
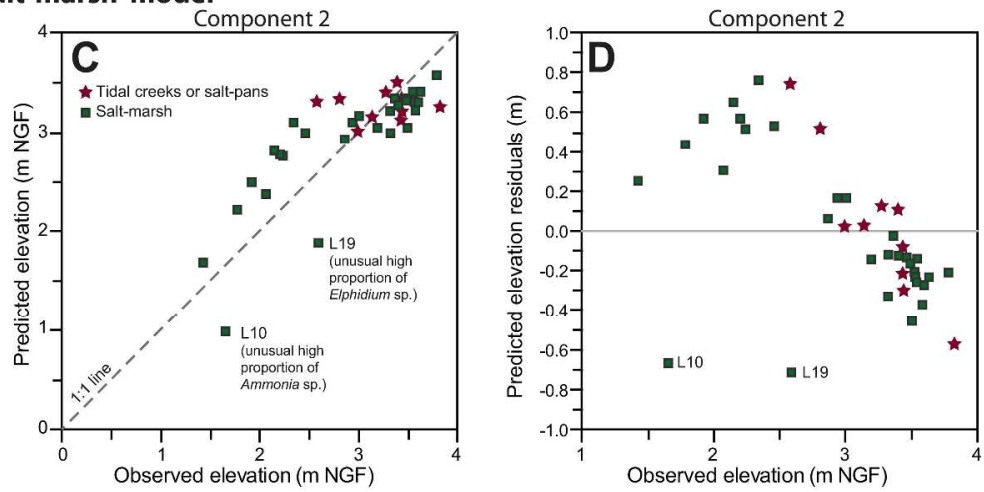

3-'pruned' salt-marsh model
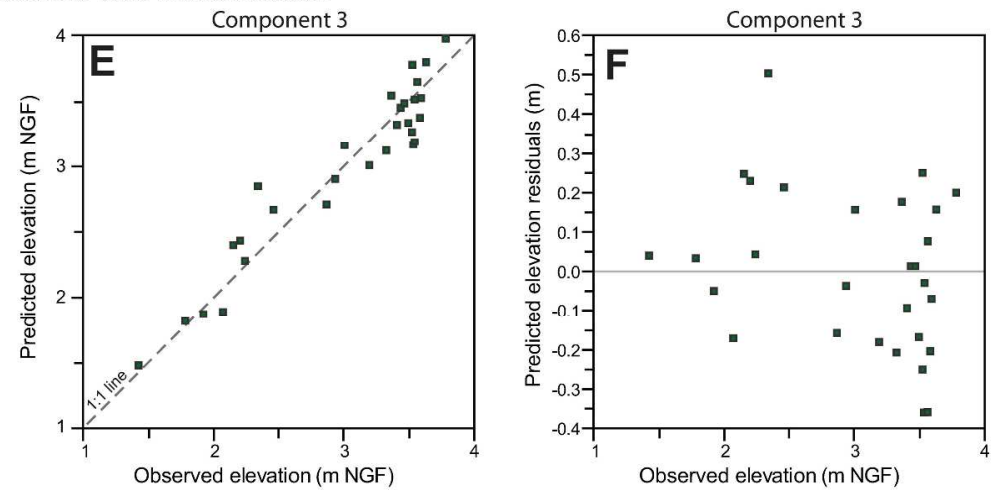

$277 \times 414 \mathrm{~mm}(300 \times 300$ DPI $)$ 
Page 53 of 68

Boreas

1
2
3
4
5
6
7
8
9
10
11
12
13
14
15
16
17
18
19
20
21
22
23
24
25
26
27
28
29
30
31
32
33
34
35
36
37
38
39
40
41
42
43
44
45
46
47
48
49
50
51
52
53
54
55
56
57
58
59
60
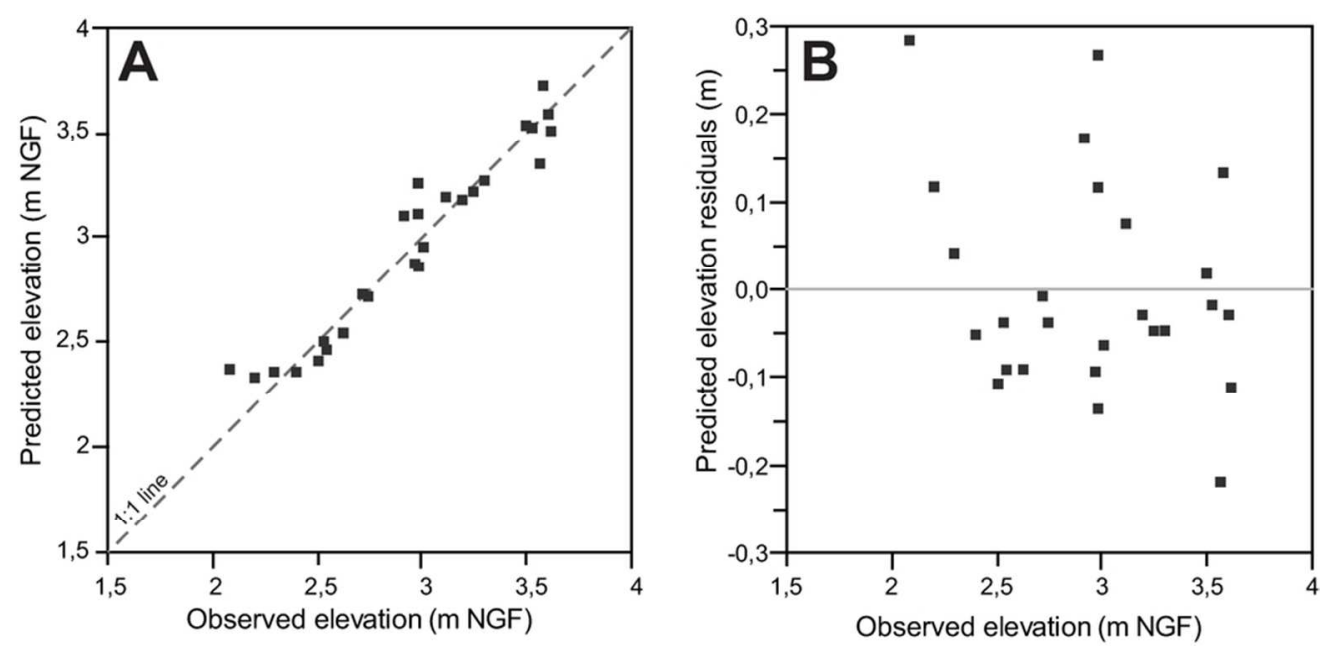

$$
84 \times 40 \mathrm{~mm}(300 \times 300 \text { DPI })
$$



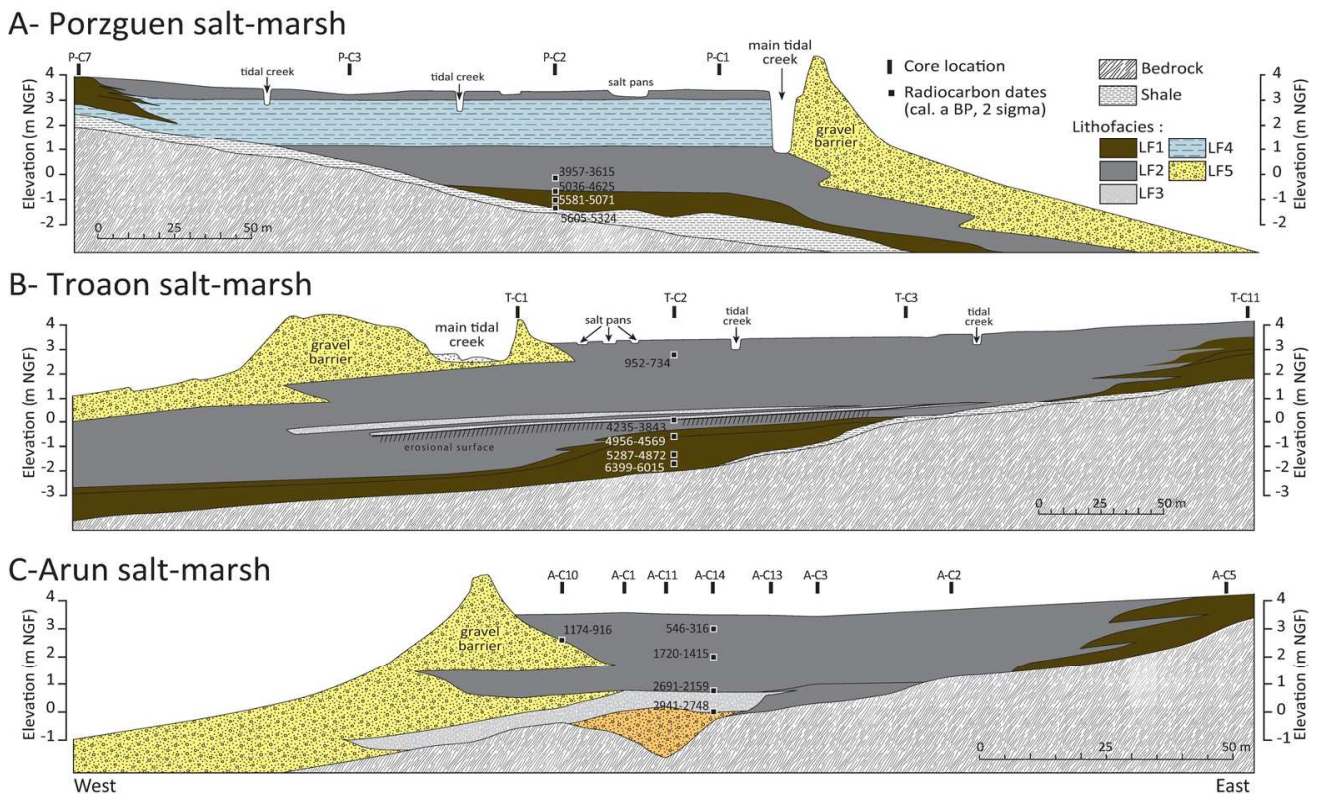

$162 \times 98 \mathrm{~mm}(300 \times 300 \mathrm{DPI})$ 


\section{Page 55 of 68}

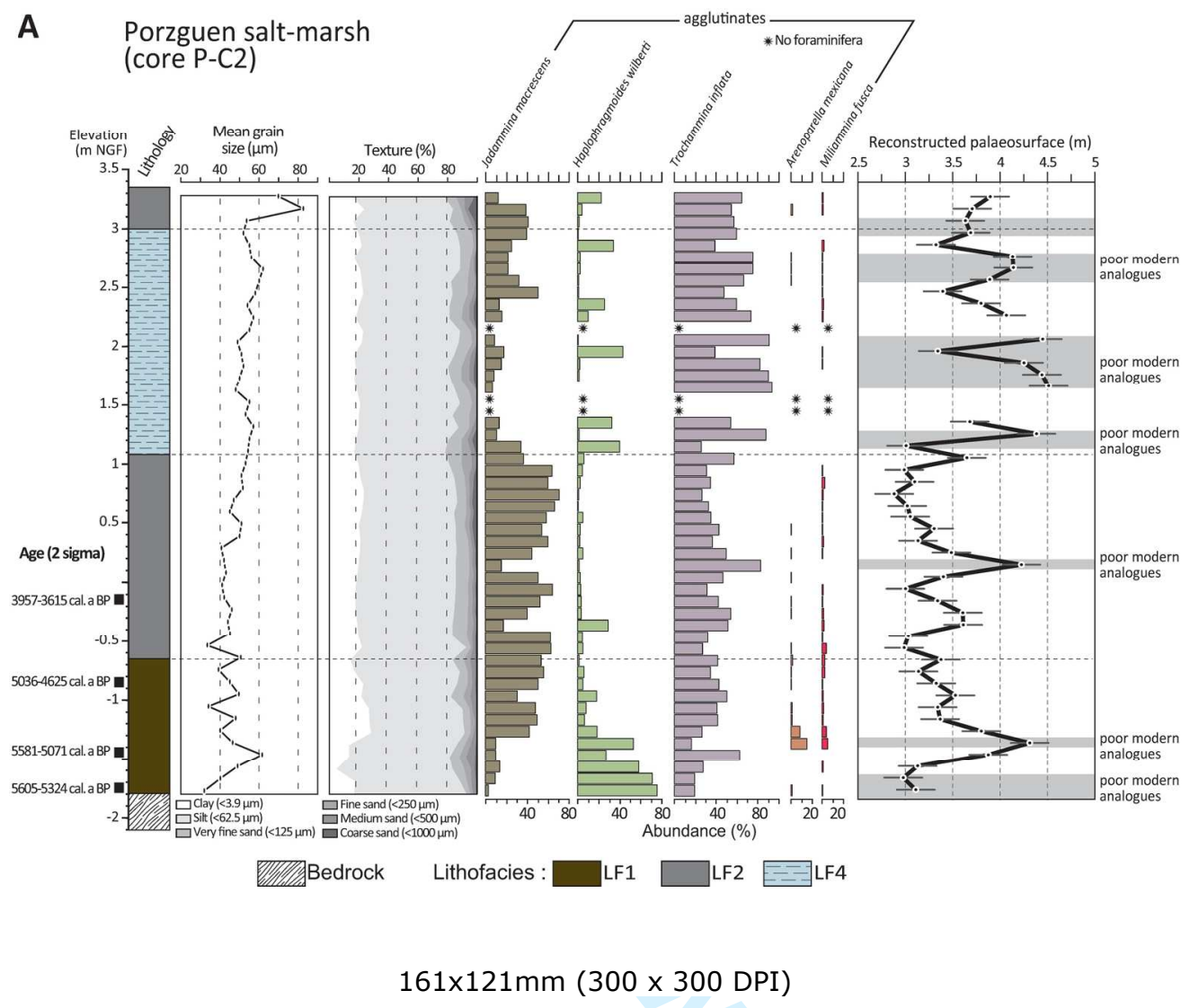




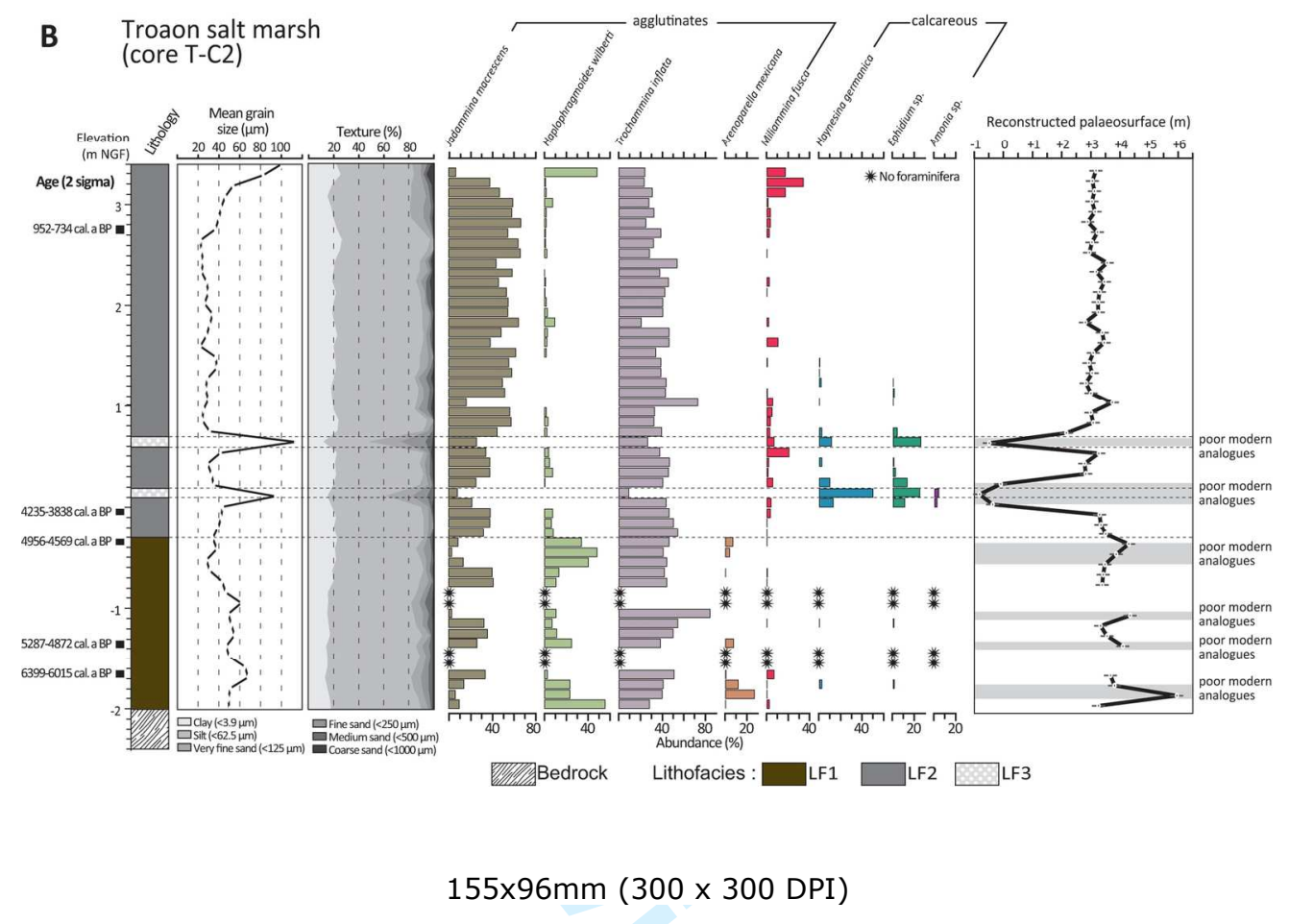

30

31

32

33

34

35

36

37

38

39

40

41

42

43

44

45

46

47

48

49

50

51

52

53

54

55

56

57

58

59

60 
Page 57 of 68

Boreas

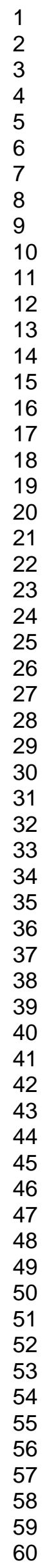

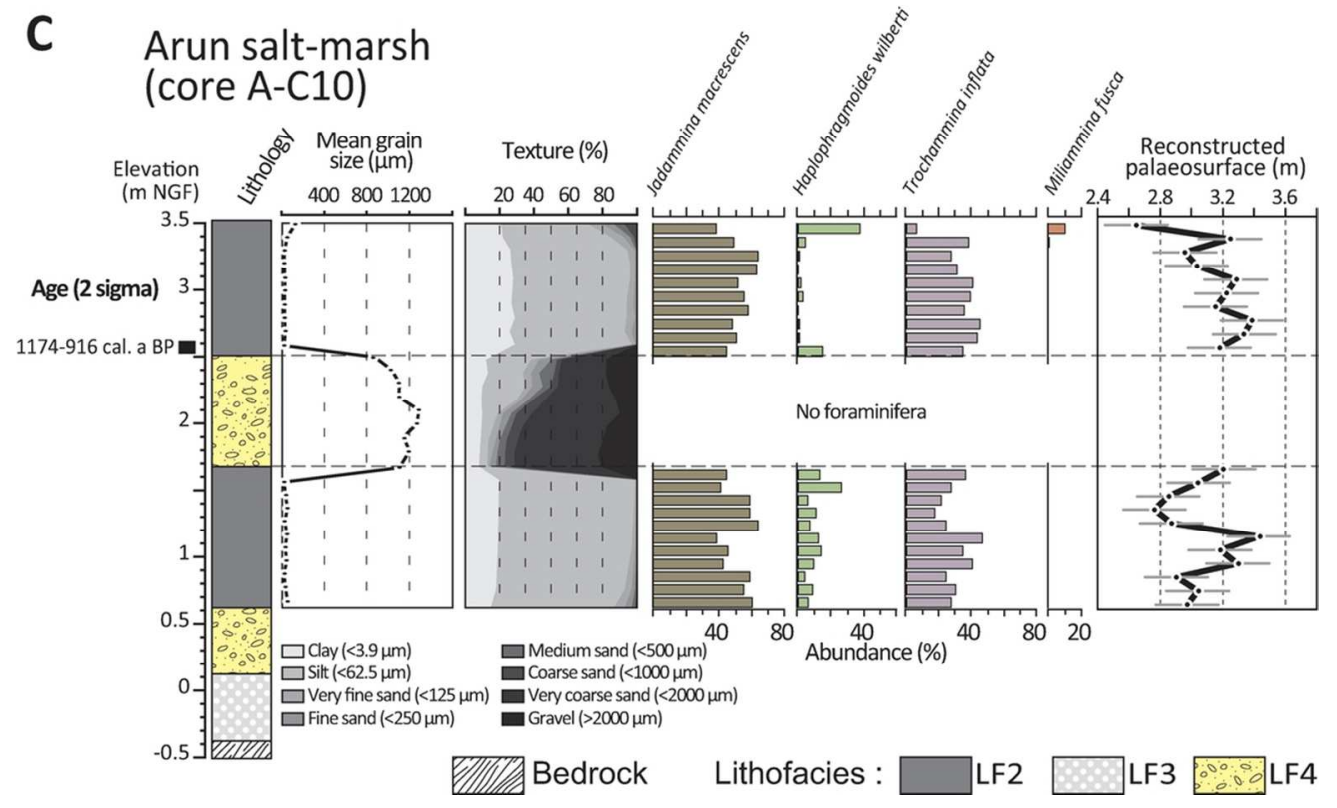

$97 \times 59 \mathrm{~mm}(300 \times 300 \mathrm{DPI})$ 


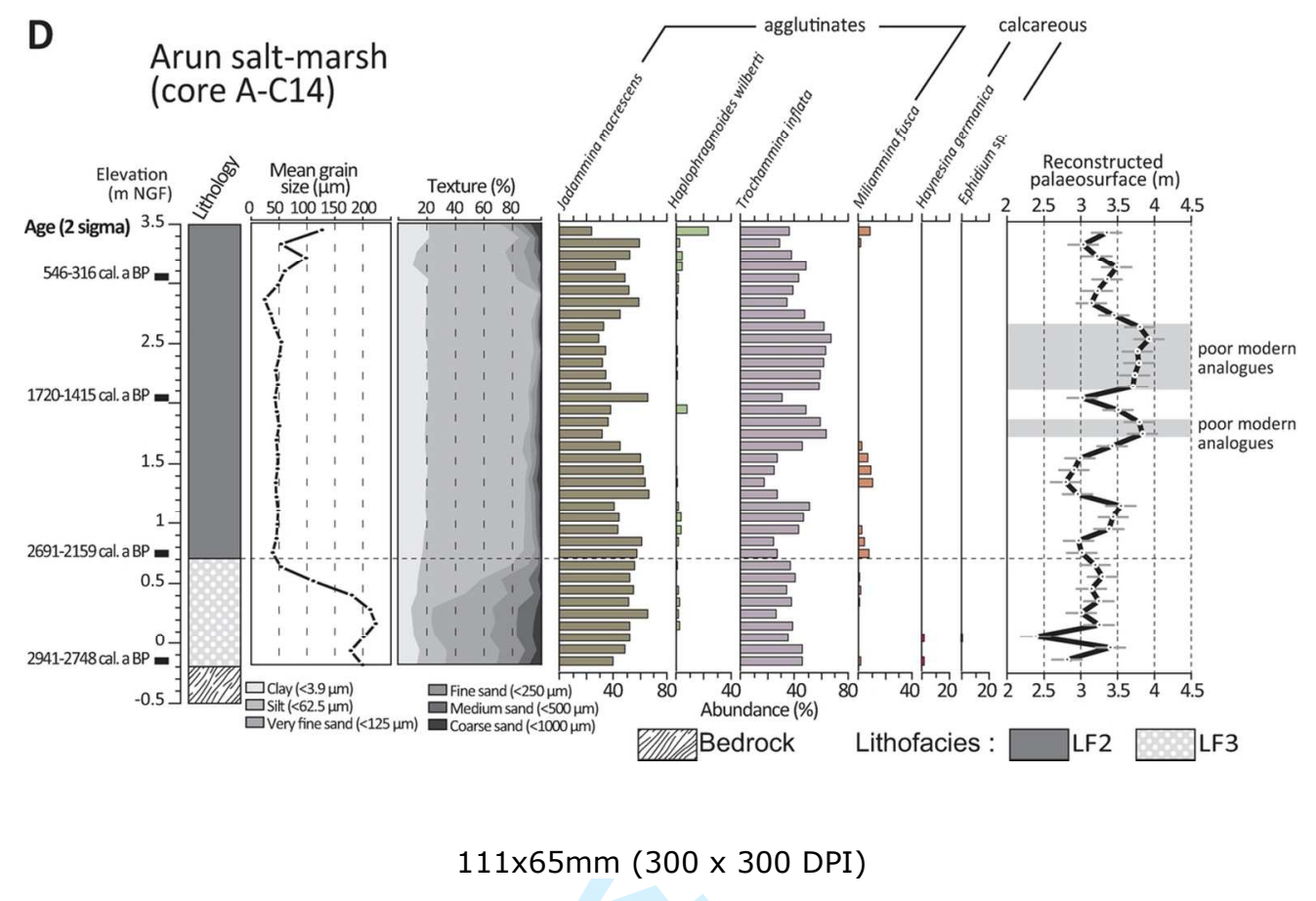




\section{Page 59 of 68}

\section{Boreas}
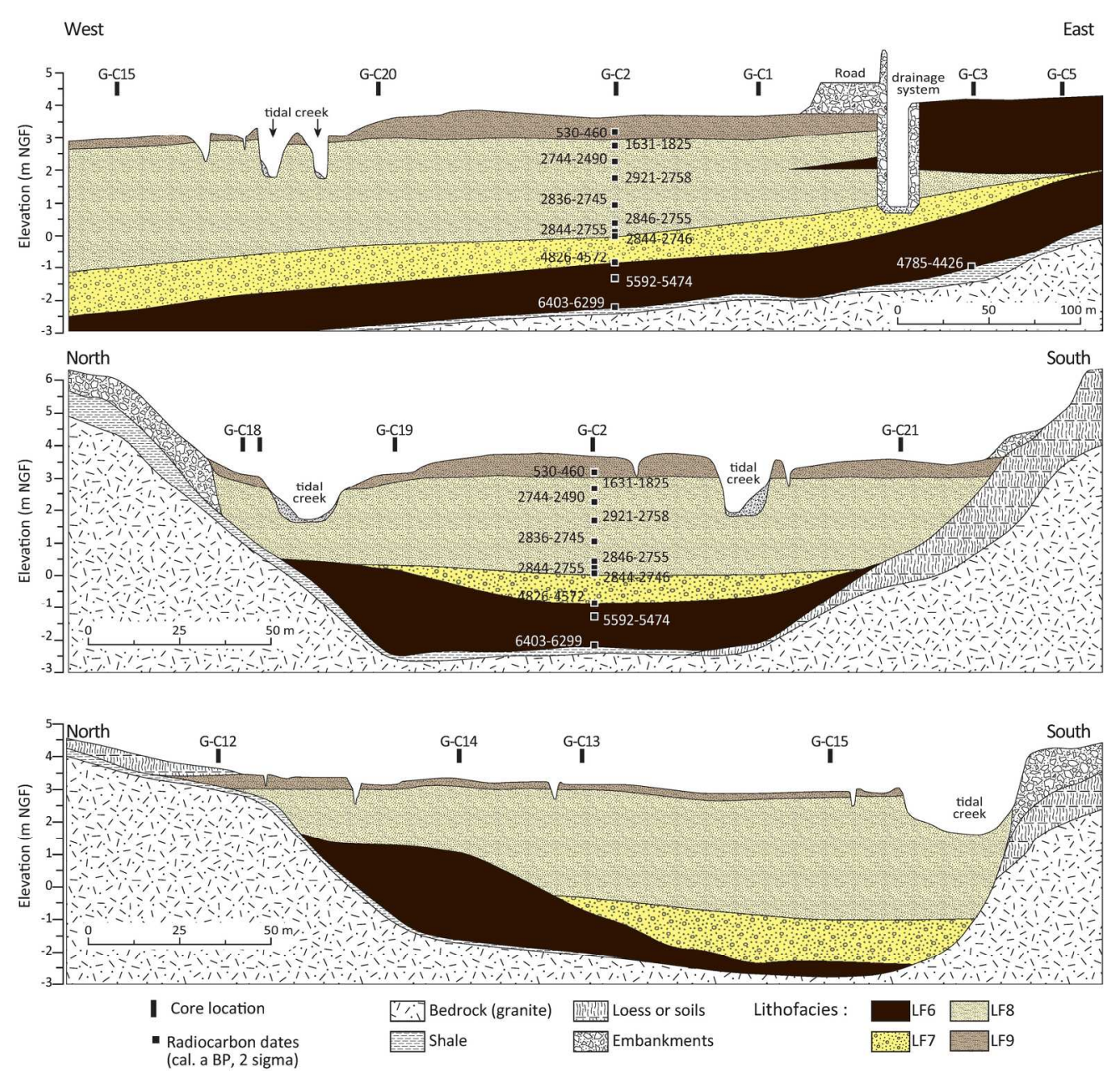

$179 \times 173 \mathrm{~mm}(300 \times 300$ DPI $)$ 


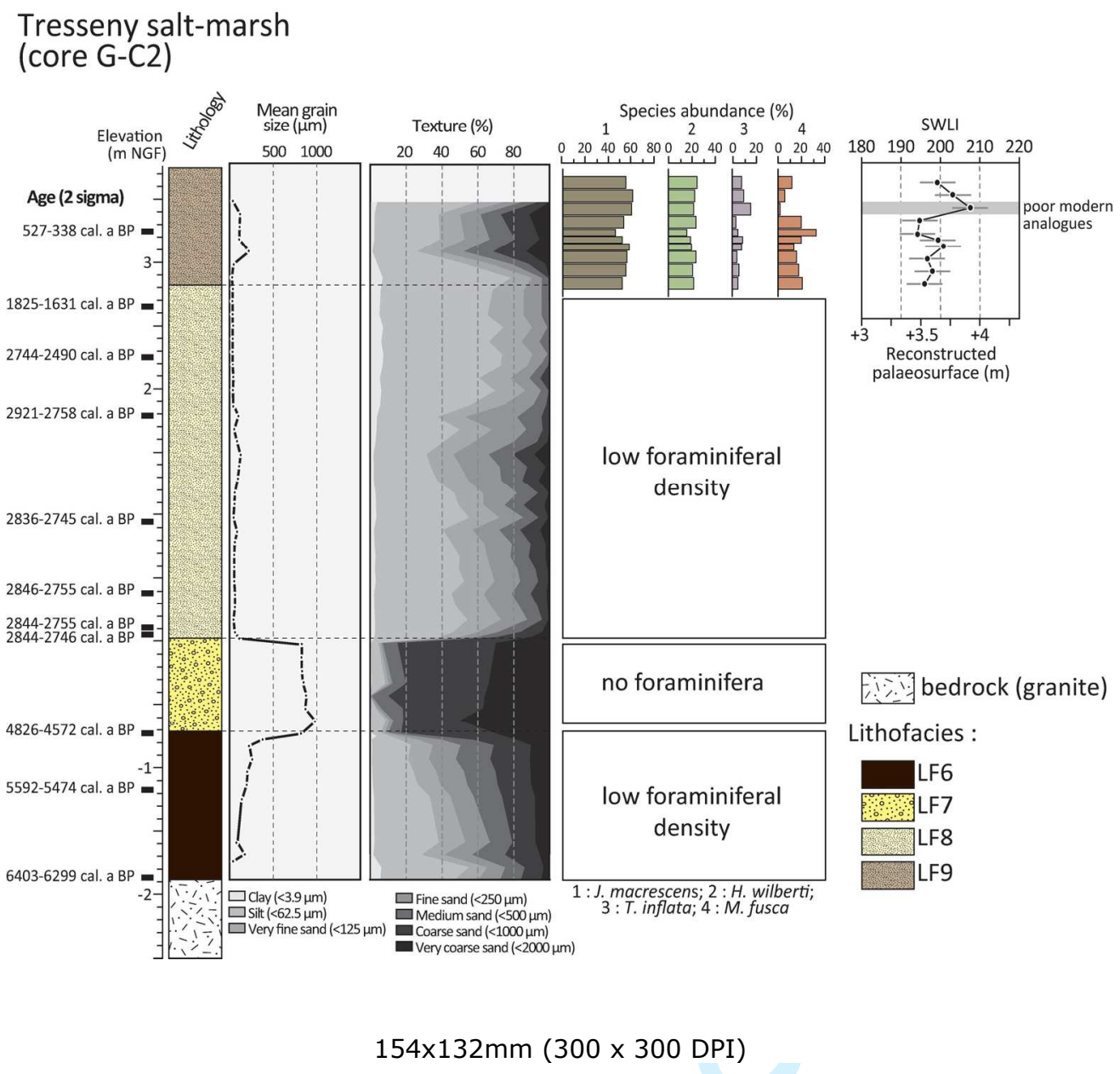


A

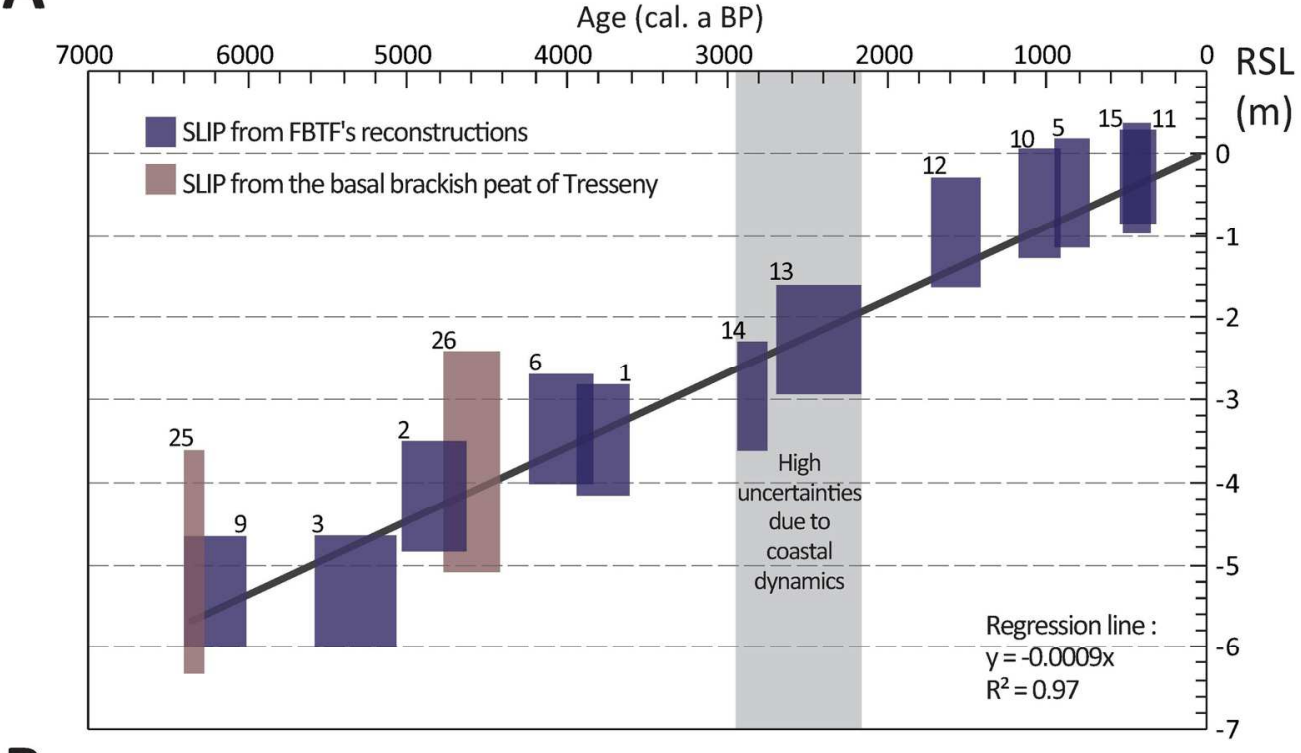

B

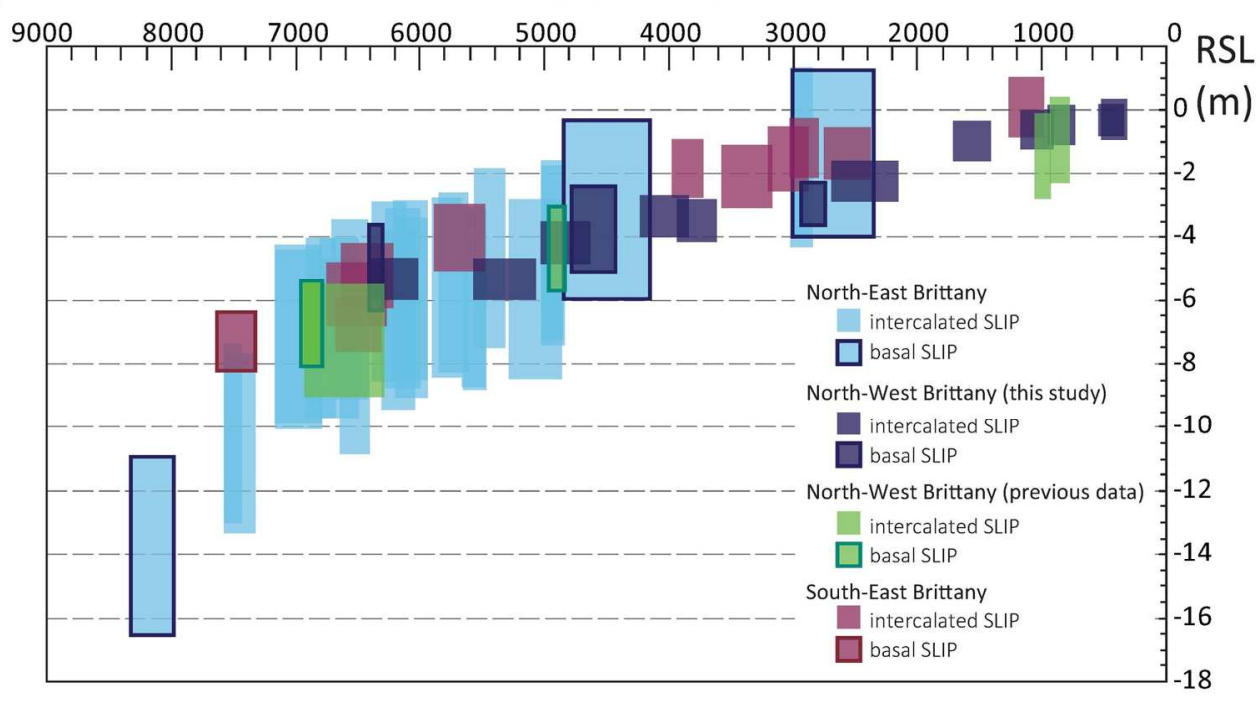

$164 \times 194 \mathrm{~mm}(300 \times 300$ DPI $)$ 
Table S1. Relative total (dead and alive) abundances of foraminifera taxa found within the modern samples collected from cross-marsh transects at Arun, Lanveur and Tresseny.

\begin{tabular}{|c|c|c|c|c|c|c|c|c|c|c|c|c|c|c|c|c|c|c|}
\hline \multirow[b]{2}{*}{ Salt-marsh } & \multirow[b]{2}{*}{$\begin{array}{l}\text { Sample } \\
\text { code }\end{array}$} & \multirow[b]{2}{*}{$\begin{array}{l}\text { Elevation } \\
\text { (m NGF) }\end{array}$} & \multirow[b]{2}{*}{$\begin{array}{l}\text { Elevation } \\
\text { (SWLI) }\end{array}$} & \multirow[b]{2}{*}{$\begin{array}{l}\text { Jadammina } \\
\text { macrescens }\end{array}$} & \multirow[b]{2}{*}{$\begin{array}{l}\text { Haplophragmoides } \\
\text { wilberti }\end{array}$} & \multirow[b]{2}{*}{$\begin{array}{l}\text { Trochammina } \\
\text { inflata }\end{array}$} & \multirow[b]{2}{*}{$\begin{array}{l}\text { Arenoparella } \\
\text { mexicana }\end{array}$} & \multirow[b]{2}{*}{$\begin{array}{l}\text { Miliammin } \\
\text { a fusca }\end{array}$} & \multirow[b]{2}{*}{$\begin{array}{l}\text { Haynesina } \\
\text { germanica }\end{array}$} & \multirow[b]{2}{*}{$\begin{array}{l}\text { Elphidium } \\
\text { sp. }\end{array}$} & \multirow[b]{2}{*}{$\begin{array}{c}\text { Ammonia } \\
\text { sp. }\end{array}$} & \multirow[b]{2}{*}{$\begin{array}{l}\text { Other } \\
\text { species } \\
\text { (A) }\end{array}$} & & & (A) Others & Decies & & \\
\hline & & & & & & & & & & & & & $\begin{array}{l}\text { Lagena } \\
\text { sulcata }\end{array}$ & $\begin{array}{l}\text { Fissurina } \\
\text { lucida }\end{array}$ & $\begin{array}{l}\text { Quinqueloculina } \\
s p .\end{array}$ & $\begin{array}{l}\text { Favulina } \\
\text { squamosa }\end{array}$ & $\begin{array}{c}\text { Hopkinsina } \\
\text { atlanticus }\end{array}$ & $\begin{array}{l}\text { Bolivina } \\
\text { variabilis }\end{array}$ \\
\hline Arun & A01 & 3,40 & 191,23 & 46,00 & 5,00 & 35,00 & 1,33 & 12,67 & 0,00 & 0,00 & 0,00 & 0,00 & 0,00 & 0,00 & 0,00 & 0,00 & 0,00 & 0,00 \\
\hline Arun & A02 & 3,32 & 188,76 & 53,80 & 1,98 & 33,00 & 0,00 & 11,22 & 0,00 & 0,00 & 0,00 & 0,00 & 0,00 & 0,00 & 0,00 & 0,00 & 0,00 & 0,00 \\
\hline Arun & $\mathrm{A} 03$ & 3,44 & 192,17 & 65,02 & 4,95 & 10,53 & 1,55 & 17,96 & 0,00 & 0,00 & 0,00 & 0,00 & 0,00 & 0,00 & 0,00 & 0,00 & 0,00 & 0,00 \\
\hline Arun & A04 & 3,13 & 183,05 & 53,59 & 4,58 & 20,92 & 0,98 & 19,93 & 0,00 & 0,00 & 0,00 & 0,00 & 0,00 & 0,00 & 0,00 & 0,00 & 0,00 & 0,00 \\
\hline Arun & A05 & 3,43 & 192,02 & 28,39 & 8,71 & 39,68 & 2,58 & 20,65 & 0,00 & 0,00 & 0,00 & 0,00 & 0,00 & 0,00 & 0,00 & 0,00 & 0,00 & 0,00 \\
\hline Arun & A06 & 3,52 & 194,71 & 50,50 & 4,95 & 27,72 & 2,64 & 14,19 & 0,00 & 0,00 & 0,00 & 0,00 & 0,00 & 0,00 & 0,00 & 0,00 & 0,00 & 0,00 \\
\hline Arun & A07 & 3,55 & 195,49 & 55,72 & 4,82 & 24,70 & 2,71 & 12,05 & 0,00 & 0,00 & 0,00 & 0,00 & 0,00 & 0,00 & 0,00 & 0,00 & 0,00 & 0,00 \\
\hline Arun & A08 & 3,55 & 195,49 & 47,18 & $\begin{array}{l}4,87 \\
\end{array}$ & 30,51 & 4,62 & 12,82 & 0,00 & 0,00 & 0,00 & 0,00 & 0,00 & 0,00 & 0,00 & 0,00 & 0,00 & 0,00 \\
\hline Arun & A09 & 3,50 & 194,13 & 12,80 & 3,05 & 22,26 & 1,22 & 60,67 & 0,00 & 0,00 & 0,00 & 0,00 & 0,00 & 0,00 & 0,00 & 0,00 & 0,00 & 0,00 \\
\hline Arun & $\mathrm{A} 10$ & 3,33 & 188,97 & 69,23 & 7,69 & 0,00 & 0,00 & 23,08 & 0,00 & 0,00 & 0,00 & 0,00 & 0,00 & 0,00 & 0,00 & 0,00 & 0,00 & 0,00 \\
\hline Arun & A11 & 3,53 & 195,01 & 6,19 & 52,12 & 24,43 & 0,33 & 16,94 & 0,00 & 0,00 & 0,00 & 0,00 & 0,00 & 0,00 & 0,00 & 0,00 & 0,00 & 0,00 \\
\hline Arun & A12 & 3,43 & 161,81 & 16,04 & 30,72 & 28,33 & 2,73 & 22,18 & 0,00 & 0,00 & 0,00 & 0,00 & 0,00 & 0,00 & 0,00 & 0,00 & 0,00 & 0,00 \\
\hline Arun & $\mathrm{A} 13$ & 3,39 & 190,93 & 10,13 & 25,49 & 46,41 & 3,59 & 14,38 & 0,00 & 0,00 & 0,00 & 0,00 & 0,00 & 0,00 & 0,00 & 0,00 & 0,00 & 0,00 \\
\hline Arun & A14 & 2,99 & 178,79 & 15,03 & 20,81 & 13,29 & 0,00 & 50,87 & 0,00 & 0,00 & 0,00 & 0,00 & 0,00 & 0,00 & 0,00 & 0,00 & 0,00 & 0,00 \\
\hline Arun & A15 & 2,58 & 166,31 & 20,39 & 21,04 & 41,10 & 0,97 & 16,50 & 0,00 & 0,00 & 0,00 & 0,00 & 0,00 & 0,00 & 0,00 & 0,00 & 0,00 & 0,00 \\
\hline Arun & A16 & $\begin{array}{l}3,28 \\
3,28\end{array}$ & 187,37 & 24,06 & 39,52 & 22,34 & 3,44 & 10,65 & 0,00 & 0,00 & 0,00 & 0,00 & 0,00 & 0,00 & 0,00 & 0,00 & 0,00 & 0,00 \\
\hline Arun & A17 & 3,44 & 192,23 & 22,26 & 15,48 & 16,13 & 3,87 & 42,26 & 0,00 & 0,00 & 0,00 & 0,00 & 0,00 & 0,00 & 0,00 & 0,00 & 0,00 & 0,00 \\
\hline Arun & A18 & 3,50 & 194,04 & 6,25 & 46,13 & 29,76 & 0,89 & 16,96 & 0,00 & 0,00 & 0,00 & 0,00 & 0,00 & 0,00 & 0,00 & 0,00 & 0,00 & 0,00 \\
\hline Arun & $\mathrm{A} 19$ & 3,47 & 193,14 & 6,35 & 36,51 & 35,98 & 1,06 & 20,11 & 0,00 & 0,00 & 0,00 & 0,00 & 0,00 & 0,00 & 0,00 & 0,00 & 0,00 & 0,00 \\
\hline Arun & A20 & 3,36 & 189,96 & 5,56 & 33,33 & 36,81 & 1,39 & 22,92 & 0,00 & 0,00 & 0,00 & 0,00 & 0,00 & 0,00 & 0,00 & 0,00 & 0,00 & 0,00 \\
\hline Arun & A21 & 2,81 & 173,23 & 6,29 & 24,25 & 50,30 & 0,00 & 19,16 & 0,00 & 0,00 & 0,00 & 0,00 & 0,00 & 0,00 & 0,00 & 0,00 & 0,00 & 0,00 \\
\hline Arun & A22 & 3,58 & 196,61 & 9,69 & 24,69 & 35,00 & 0,00 & 30,63 & 0,00 & 0,00 & 0,00 & 0,00 & 0,00 & 0,00 & 0,00 & 0,00 & 0,00 & 0,00 \\
\hline Arun & A23 & 3,59 & 196,97 & 4,83 & 33,51 & 41,29 & 0,27 & 20,11 & 0,00 & 0,00 & 0,00 & 0,00 & 0,00 & 0,00 & 0,00 & 0,00 & 0,00 & 0,00 \\
\hline Arun & A24 & 3,57 & 196,10 & 26,97 & 6,25 & 51,64 & 0,33 & 14,80 & 0,00 & 0,00 & 0,00 & 0,00 & 0,00 & 0,00 & 0,00 & 0,00 & 0,00 & 0,00 \\
\hline Arun & A25 & 3,52 & 194,77 & 6,87 & 13,49 & 45,29 & 1,78 & 32,57 & 0,00 & 0,00 & 0,00 & 0,00 & 0,00 & 0,00 & 0,00 & 0,00 & 0,00 & 0,00 \\
\hline Arun & A26 & 3,63 & 198,15 & 13,01 & 19,86 & 56,51 & 0,34 & 10,27 & 0,00 & 0,00 & 0,00 & 0,00 & 0,00 & 0,00 & 0,00 & 0,00 & 0,00 & 0,00 \\
\hline Arun & A27 & 3,78 & 202,71 & 21,33 & 17,00 & 33,67 & 7,67 & 20,33 & 0,00 & 0,00 & 0,00 & 0,00 & 0,00 & 0,00 & 0,00 & 0,00 & 0,00 & 0,00 \\
\hline Arun & A28 & 3,82 & 203,92 & 42,97 & 42,19 & 10,94 & 0,78 & 3,13 & 0,00 & 0,00 & 0,00 & 0,00 & 0,00 & 0,00 & 0,00 & 0,00 & 0,00 & 0,00 \\
\hline Lanveur & L01 & 0,55 & 105,14 & 0,00 & 0,00 & 0,00 & 0,00 & 0,00 & 65,15 & 2,28 & 31,92 & 0,65 & 0,00 & 0,00 & 0,65 & 0,00 & 0,00 & 0,00 \\
\hline Lanveur & L02 & 0,65 & 108,04 & 0,00 & 0,00 & 0,00 & 0,00 & 0,00 & 53,01 & 10,24 & 35,54 & 1,20 & 0,00 & 0,00 & 1,20 & 0,00 & 0,00 & 0,00 \\
\hline Lanveur & L03 & 0,68 & 109,00 & 0,00 & 0,00 & 0,00 & 0,00 & 0,66 & 43,19 & 5,65 & 49,83 & 0,66 & 0,00 & 0,00 & 0,66 & 0,00 & 0,00 & 0,00 \\
\hline Lanveur & L04 & $\begin{array}{l}0,00 \\
0,77\end{array}$ & 111,54 & 0,00 & 0,00 & 0,00 & 0,00 & $\begin{array}{l}0,00 \\
0,00\end{array}$ & $\begin{array}{l}52,98 \\
52,19\end{array}$ & $\begin{array}{l}6,63 \\
6,62\end{array}$ & $\begin{array}{l}45,100 \\
31,13\end{array}$ & $\begin{array}{l}9,27 \\
9,27\end{array}$ & 2,23 & 1,48 & $\begin{array}{l}3,00 \\
3,71\end{array}$ & 1,11 & 0,37 & 0,37 \\
\hline Lanveur & L05 & 0,80 & 112,63 & 0,00 & 0,00 & 0,00 & 0,00 & 3,66 & 30,18 & 5,79 & 56,71 & 3,66 & 0,73 & 0,37 & 2,20 & 0,37 & 0,00 & 0,00 \\
\hline Lanveur & L06 & 0,95 & 116,98 & 0,33 & 0,33 & 0,33 & 0,00 & 8,17 & 38,24 & 7,84 & 44,77 & 0,00 & 0,00 & 0,00 & 0,00 & 0,00 & 0,00 & 0,00 \\
\hline Lanveur & L07 & 1,09 & 121,42 & 1,30 & 0,33 & 0,33 & 0,00 & 22,80 & 22,48 & 12,70 & 40,07 & 0,00 & 0,00 & 0,00 & 0,00 & 0,00 & 0,00 & 0,00 \\
\hline Lanveur & L08 & $\begin{array}{l}1,24 \\
1,24\end{array}$ & 125,92 & $\begin{array}{l}1,00 \\
1,69\end{array}$ & 0,68 & $\begin{array}{l}1,02 \\
1,02\end{array}$ & 0,00 & $\begin{array}{l}76,90 \\
76,95\end{array}$ & $\begin{array}{l}2<, 40 \\
3,73\end{array}$ & 6,44 & 9,15 & 0,34 & 0,00 & 0,00 & 0,34 & 0,00 & 0,00 & 0,00 \\
\hline Lanveur & L09 & 1,43 & 131,66 & 1,53 & 5,34 & 1,15 & 0,00 & 80,92 & 1,91 & 1,15 & 8,02 & 0,00 & 0,00 & 0,00 & 0,00 & 0,00 & 0,00 & 0,00 \\
\hline Lanveur & L10 & 1,65 & 138,37 & 29,61 & 4,29 & 12,02 & 1,72 & 30,47 & 0,43 & 1,72 & 19,31 & 0,43 & 0,00 & 0,00 & 0,43 & 0,00 & 0,00 & 0,00 \\
\hline Lanveur & L11 & $\begin{array}{l}1,08 \\
\text {. }\end{array}$ & 142,20 & 35,50 & $\begin{array}{l}0,38 \\
0,38\end{array}$ & 8,02 & 0,00 & 48,86 & 0,38 & 2,29 & 4,58 & 0,00 & 0,00 & 0,00 & 0,00 & 0,00 & 0,00 & 0,00 \\
\hline Lanveur & L12 & 1,93 & 146,55 & 62,72 & 0,00 & 7,89 & 0,36 & 23,66 & 0,36 & 2,87 & 2,15 & 0,00 & 0,00 & 0,00 & 0,00 & 0,00 & 0,00 & 0,00 \\
\hline Lanveur & L13 & 2,07 & 150,90 & 44,98 & 2,27 & 29,45 & 0,32 & 14,89 & 0,32 & 6,80 & 0,97 & 0,00 & 0,00 & 0,00 & 0,00 & 0,00 & 0,00 & 0,00 \\
\hline Lanveur & L14 & 2,16 & 153,56 & 47,98 & $\begin{array}{l}13,08 \\
13,1\end{array}$ & 26,79 & 0,00 & 8,10 & 0,00 & 3,12 & 0,93 & 0,00 & 0,00 & 0,00 & 0,00 & 0,00 & 0,00 & 0,00 \\
\hline Lanveur & L15 & 2,20 & 154,95 & 48,33 & 13,67 & 24,67 & 0,00 & 9,33 & 1,00 & 1,33 & 1,67 & 0,00 & 0,00 & 0,00 & 0,00 & 0,00 & 0,00 & 0,00 \\
\hline Lanveur & L16 & 2,24 & 156,01 & 40,00 & 20,94 & 20,00 & 0,94 & 13,44 & 0,00 & 4,06 & 0,63 & 0,00 & 0,00 & 0,0 & 0,00 & 0,00 & 0,00 & 0,00 \\
\hline Lanveur & L17 & 2,34 & 159,06 & 42,12 & 18,01 & $\begin{array}{l}19,94 \\
\text { a }\end{array}$ & 0,96 & 18,01 & 0,00 & 0,96 & 0,00 & 0,00 & 0,00 & 0,00 & 0,00 & 0,00 & 0,00 & 0,00 \\
\hline Lanveur & L18 & $\begin{array}{l}2,04 \\
2,46\end{array}$ & 162,75 & 44,30 & 14,98 & 21,50 & 0,00 & 17,59 & 0,00 & $\begin{array}{l}1,63 \\
1,63\end{array}$ & 0,00 & 0,00 & 0,00 & 0,00 & 0,00 & 0,00 & 0,00 & 0,00 \\
\hline Lanveur & L19 & 2,59 & 166,70 & 28,71 & 11,88 & 11,55 & 0,00 & 36,30 & 0,33 & 9,90 & 1,32 & 0,00 & 0,00 & 0,00 & 0,00 & 0,00 & 0,00 & 0,00 \\
\hline Lanveur & L20 & 2,86 & 174,89 & 33,45 & 13,38 & 12,32 & 0,70 & 38,73 & 0,00 & 0,70 & 0,70 & 0,00 & 0,00 & 0,00 & 0,00 & 0,00 & 0,00 & 0,00 \\
\hline Lanveur & L21 & 2,94 & 177,10 & 38,79 & 14,23 & 10,68 & 1,42 & 34,88 & 0,00 & 0,00 & 0,00 & 0,00 & 0,00 & 0,00 & 0,00 & 0,00 & 0,00 & 0,00 \\
\hline Lanveur & L22 & 3,00 & 179,12 & 30,23 & 11,96 & 13,95 & 2,99 & 40,86 & 0,00 & 0,00 & 0,00 & 0,00 & 0,00 & 0,00 & 0,00 & 0,00 & 0,00 & 0,00 \\
\hline Lanveur & L23 & 3,19 & 184,83 & 30,23 & 11,63 & 10,30 & 3,99 & 42,52 & 0,33 & 0,33 & 0,66 & 0,00 & 0,00 & 0,00 & 0,00 & 0,00 & 0,00 & 0,00 \\
\hline
\end{tabular}




\section{Page 63 of 68}

\section{Boreas}

\begin{tabular}{|c|c|c|c|c|c|c|c|c|c|c|c|c|c|c|c|c|c|c|}
\hline Tresseny & T01 & 3,62 & 198,02 & 51,94 & 21,20 & 3,18 & 0,00 & 23,67 & 0,00 & 0,00 & 0,00 & 0,00 & 0,00 & 0,00 & 0,00 & 0,00 & 0,00 & 0,00 \\
\hline Tresseny & T02 & 3,61 & 197,72 & 63,57 & 16,43 & 0,00 & 0,00 & 20,00 & 0,00 & 0,00 & 0,00 & 0,00 & 0,00 & 0,00 & 0,00 & 0,00 & 0,00 & 0,00 \\
\hline Tresseny & T03 & 3,58 & 196,93 & 64,04 & 14,51 & 5,05 & 0,00 & 16,40 & 0,00 & 0,00 & 0,00 & 0,00 & 0,00 & 0,00 & 0,00 & 0,00 & 0,00 & 0,00 \\
\hline Tresseny & T04 & 3,57 & 196,38 & 42,33 & 16,67 & 1,33 & 0,00 & 39,67 & 0,00 & 0,00 & 0,00 & 0,00 & 0,00 & 0,00 & 0,00 & 0,00 & 0,00 & 0,00 \\
\hline Tresseny & T05 & 3,53 & 195,35 & 55,37 & 19,54 & 1,63 & 0,00 & 23,45 & 0,00 & 0,00 & 0,00 & 0,00 & 0,00 & 0,00 & 0,00 & 0,00 & 0,00 & 0,00 \\
\hline Tresseny & T06 & 3,51 & 194,59 & 55,24 & 19,23 & 2,10 & 0,00 & 23,43 & 0,00 & 0,00 & 0,00 & 0,00 & 0,00 & 0,00 & 0,00 & 0,00 & 0,00 & 0,00 \\
\hline Tresseny & T07 & 3,31 & 188,63 & 37,91 & 14,71 & 0,00 & 0,00 & 47,39 & 0,00 & 0,00 & 0,00 & 0,00 & 0,00 & 0,00 & 0,00 & 0,00 & 0,00 & 0,00 \\
\hline Tresseny & T08 & 3,26 & 187,05 & 34,13 & 17,75 & 0,00 & 0,00 & 48,12 & 0,00 & 0,00 & 0,00 & 0,00 & 0,00 & 0,00 & 0,00 & 0,00 & 0,00 & 0,00 \\
\hline Tresseny & $\begin{array}{l}\text { T09 } \\
\text { The }\end{array}$ & $\begin{array}{l}3,20 \\
3,20\end{array}$ & 185,35 & $\begin{array}{l}31,33 \\
31,33\end{array}$ & 19,33 & 0,00 & 0,00 & 49,33 & 0,00 & 0,00 & 0,00 & 0,00 & 0,00 & 0,00 & 0,00 & 0,00 & 0,00 & 0,00 \\
\hline Tresseny & T10 & 3,12 & 182,77 & 32,45 & 15,89 & 0,00 & 0,00 & 51,66 & 0,00 & 0,00 & 0,00 & 0,00 & 0,00 & 0,00 & 0,00 & 0,00 & 0,00 & 0,00 \\
\hline Tresseny & $\mathrm{T} 11$ & 3,01 & 179,64 & 15,85 & 37,80 & 0,00 & 0,00 & 46,34 & 0,00 & 0,00 & 0,00 & 0,00 & 0,00 & 0,00 & 0,00 & 0,00 & 0,00 & 0,00 \\
\hline Tresseny & $\mathrm{T} 12$ & 2,97 & 178,21 & 13,10 & 40,34 & 0,00 & 1,72 & 44,83 & 0,00 & 0,00 & 0,00 & 0,00 & 0,00 & 0,00 & 0,00 & 0,00 & 0,00 & 0,00 \\
\hline Tresseny & T13 & 2,92 & 176,81 & 28,95 & 37,17 & 0,00 & 0,99 & $\begin{array}{l}32,89 \\
32,89\end{array}$ & 0,00 & 0,00 & 0,00 & 0,00 & 0,00 & 0,00 & 0,00 & 0,00 & 0,00 & 0,00 \\
\hline Tresseny & T14 & 2,72 & 170,79 & 4,88 & 3,66 & 0,00 & 0,00 & 58,54 & 25,00 & 6,71 & 0,61 & 0,61 & 0,00 & 0,00 & 0,61 & 0,00 & 0,00 & 0,00 \\
\hline Tresseny & T15 & 2,99 & 178,84 & 39,74 & 34,29 & 0,00 & 0,00 & 25,96 & 0,00 & 0,00 & 0,00 & 0,00 & 0,00 & 0,00 & 0,00 & 0,00 & 0,00 & 0,00 \\
\hline Tresseny & T16 & 2,99 & 178,88 & 26,85 & 42,28 & $\begin{array}{l}1,01 \\
1,0\end{array}$ & 0,00 & 26,17 & 1,68 & 0,00 & 2,01 & 0,00 & 0,00 & 0,00 & 0,00 & 0,00 & 0,00 & 0,00 \\
\hline Tresseny & T17 & 2,99 & 178,88 & 15,41 & 33,44 & 0,00 & 0,00 & 22,95 & 17,70 & 3,93 & 5,25 & 1,31 & 0,33 & 0,33 & 0,33 & 0,00 & 0,33 & 0,00 \\
\hline Tresseny & T18 & 2,75 & 171,49 & 5,77 & 19,87 & 0,32 & 0,00 & 20,19 & 32,05 & 4,81 & 13,46 & 3,53 & 0,64 & 0,64 & 0,96 & 0,00 & 0,00 & 1,28 \\
\hline Tresseny & T19 & 2,63 & 167,81 & 0,99 & 3,96 & 0,00 & 0,00 & 5,61 & 56,44 & 9,57 & $\begin{array}{l}17,82 \\
17,0\end{array}$ & 5,61 & 0,00 & 1,65 & 2,64 & 0,00 & 0,00 & 1,32 \\
\hline Tresseny & T20 & 2,55 & 165,41 & 0,00 & 0,00 & 0,00 & 0,00 & 0,00 & 64,09 & 13,76 & 15,44 & 6,71 & 1,01 & 1,68 & 2,68 & 0,00 & 0,00 & 1,34 \\
\hline Tresseny & $\mathrm{T} 21$ & 2,53 & 164,98 & 0,00 & 0,33 & 0,00 & 0,00 & 4,01 & 39,80 & 32,11 & 14,38 & 9,36 & 1,67 & 2,01 & 4,68 & 0,00 & 0,00 & 1,00 \\
\hline Tresseny & T22 & 2,51 & 164,32 & 0,00 & 0,64 & 0,00 & 0,00 & 0,00 & 69,77 & 15,76 & 8,68 & 5,14 & 0,64 & 1,29 & 2,57 & 0,00 & 0,00 & 0,64 \\
\hline Tresseny & T23 & 2,41 & $\begin{array}{l}161,16 \\
161,0<\end{array}$ & 0,00 & 0,31 & 0,00 & 0,00 & 2,47 & 69,14 & 15,12 & $\begin{array}{l}3,00 \\
3,70\end{array}$ & 9,26 & $\begin{array}{l}1,54 \\
1,54\end{array}$ & $\begin{array}{l}0,93 \\
0,93\end{array}$ & 6,17 & 0,31 & 0,00 & 0,31 \\
\hline Tresseny & T24 & 2,30 & 158,05 & 0,62 & 0,93 & 0,62 & 0,00 & 1,24 & 68,32 & 15,53 & 0,00 & 12,73 & 1,86 & 1,86 & 8,07 & 0,31 & 0,00 & 0,62 \\
\hline Tresseny & T25 & 2,21 & 155,23 & 0,00 & 1,34 & 0,00 & 0,00 & 1,67 & 72,58 & 15,05 & 0,67 & 8,70 & 2,01 & 1,00 & 5,69 & 0,00 & 0,00 & 0,00 \\
\hline Tresseny & T26 & 2.08 & 151.34 & 031 & 0,31 & 0,00 & 0,00 & 3,74 & 65,11 & 1340 & 5,92 & 11,21 & 3.12 & 1.87 & 4.05 & 0,31 & 0,62 & $\begin{array}{l}0,25 \\
\end{array}$ \\
\hline
\end{tabular}

Tresseny T26 
Table S2. Relative total (dead and alive) abundances of foraminifera taxa found within the samples collected from the core P-C2 (Porzguen saltmarsh, bay of Brest).

\begin{tabular}{|c|c|c|c|c|c|c|c|c|c|c|c|c|c|c|c|c|c|c|c|c|c|c|}
\hline Sample code & $\begin{array}{l}\text { Elevation (m } \\
\text { NGF) }\end{array}$ & Depth $(m)$ & $\begin{array}{l}\text { Jadammina } \\
\text { macrescens }\end{array}$ & $\begin{array}{l}\text { Haplophragm } \\
\text { oides wilberti }\end{array}$ & 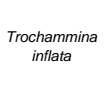 & $\begin{array}{c}\text { Arenoparalla } \\
\text { mexicana }\end{array}$ & $\begin{array}{c}\text { Miliammina } \\
\text { fuscaa }\end{array}$ & $\begin{array}{l}\text { Haynesina } \\
\text { germanica }\end{array}$ & Elphidium sp. & Ammonia sp. & $\begin{array}{l}\text { Palaeomarsh } \\
\text { elevation (m) } \\
\text { from WA-PLS } \\
\text { Modele comp } 3\end{array}$ & $\operatorname{RMSEP}(\mathrm{m})$ & MinDC & $\begin{array}{c}\text { MAT } \\
\text { diagnostic }\end{array}$ & 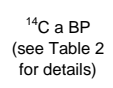 & $\begin{array}{l}\text { mid sample } \\
\text { elevation }\end{array}$ & $\operatorname{RSL}(\mathrm{m})$ & $\begin{array}{c}\text { surface } \\
\text { sampling } \\
\text { error }\end{array}$ & $\begin{array}{c}\text { core } \\
\text { sampling } \\
\text { error }\end{array}$ & $\begin{array}{c}\text { Elevation } \\
\text { error } \\
\text { (benchmark } \\
\& \text { D DPS) }\end{array}$ & $\operatorname{RMSEP}(\mathrm{m})$ & $\begin{array}{l}\text { Total error } \\
(\mathrm{m})\end{array}$ \\
\hline $\begin{array}{l}\text { P-C2-E01 } \\
\text { P-ECEOP }\end{array}$ & $\begin{array}{l}3,30 ; 3,20 \\
320 ; 310\end{array}$ & $0.00 ; 0.10$ & 12,50 & $\begin{array}{l}22,37 \\
2,35\end{array}$ & 64,14 & 0,00 & 0,99 & 0,00 & 0,00 & 0,00 & 3,89 & 0,20 & 8,64 & close & & 3,25 & $-0,64$ & 0,10 & 0,05 & 0,13 & 0,20 & 0,48 \\
\hline $\begin{array}{l}22-202 \\
22-503\end{array}$ & $\begin{array}{l}3,20 ; 3,10 \\
3,10 ;, 00\end{array}$ & $\begin{array}{l}\begin{array}{l}0.10 ; 0 ; .20 \\
0.20 .030\end{array} \\
0.00\end{array}$ & $\begin{array}{l}39,47 \\
41,56\end{array}$ & $\begin{array}{l}3,95 \\
130\end{array}$ & $\begin{array}{l}54,28 \\
5714\end{array}$ & $\begin{array}{l}, 3232 \\
0.00\end{array}$ & 0,99 & 0,00 & 0.000 & 0,00 & $\begin{array}{l}3,70 \\
3,63\end{array}$ & $\begin{array}{l}0,20 \\
0,20\end{array}$ & $\begin{array}{l}14,78 \\
1940\end{array}$ & close & & $\begin{array}{l}3,15 \\
3,05 \\
3\end{array}$ & $\begin{array}{l}-0,55 \\
-0,58\end{array}$ & 0,10 & 0,05 & 0,13 & 0,20 & \\
\hline P-C2-E04 & $\begin{array}{l}3,10,3,00 \\
3,00 ; 2,90\end{array}$ & $\begin{array}{l}0.20,0.50 \\
0.30: 0.40\end{array}$ & $\begin{array}{l}\begin{array}{l}14,56 \\
40,07\end{array} \\
-\end{array}$ & $\begin{array}{l}0,30 \\
0,33\end{array}$ & $\begin{array}{l}59,60 \\
59,60\end{array}$ & 0,00 & 0,00 & 0,00 & 0,00 & 0,00 & $\begin{array}{l}3,60 \\
3,69 \\
\end{array}$ & 0,20 & $\begin{array}{l}7,40 \\
22,05\end{array}$ & $\begin{array}{l}\text { poor } \\
\text { poor }\end{array}$ & & $\begin{array}{l}3,005 \\
2,95\end{array}$ & $\begin{array}{l}-0.74 \\
-0.74\end{array}$ & 0,10 & 0,05 & 0 & $\begin{array}{l}0,20 \\
0,20\end{array}$ & $\begin{array}{l}0,48 \\
0,48\end{array}$ \\
\hline P-C2-E05 & 2,$90 ; 2,80$ & $0.40 ; 0.50$ & 25,42 & 33,78 & 38,80 & 0,00 & 2,01 & 0,00 & 0,00 & 0,00 & 3,32 & 0,20 & 16,81 & close & & 2,85 & $-0,47$ & 0,10 & 0,05 & 0,13 & 0.20 & $\begin{array}{l}0,40 \\
0,48\end{array}$ \\
\hline P-C2-E06 & 2,$80 ; 2,70$ & $0.50 ; 0.60$ & 21,85 & 2,46 & 74,77 & 0,62 & 0,31 & 0,00 & 0,00 & 0,00 & 4,13 & 0,20 & 20,41 & poor & & 2,75 & $-1,38$ & 0,10 & 0,05 & 0,13 & 0,20 & 0,48 \\
\hline $\begin{array}{l}\text { P-C2-E07 } \\
\text { P-CE7 }\end{array}$ & $\begin{array}{l}2,70 ; 2,60 \\
2,60 \cdot 250\end{array}$ & $0.60 ; 0.70$ & $\begin{array}{l}21,78 \\
3340\end{array}$ & 2,31 & 74,92 & 0,66 & 0,33 & 0,00 & 0,00 & 0,00 & 4,14 & 0,20 & 20,60 & poor & & 2,65 & $-1,49$ & 0,10 & 0,05 & 0,13 & 0,20 & 0,48 \\
\hline $\begin{array}{l}\text { P-C2--E08 } \\
\text { P-C2-E09 }\end{array}$ & $\begin{array}{l}2,60 ; 2,50 \\
2,50 ; 2,40\end{array}$ & $\begin{array}{l}0.70 ; 0.80 \\
0.80 .090\end{array}$ & $\begin{array}{l}32,40 \\
50,90\end{array}$ & $\begin{array}{l}0,80 \\
1,20\end{array}$ & $\begin{array}{l}66,00 \\
47,31\end{array}$ & $\begin{array}{l}0,40 \\
0,00\end{array}$ & $\begin{array}{l}0,40 \\
0,60\end{array}$ & $\begin{array}{l}0,00 \\
0,00\end{array}$ & $\begin{array}{l}0,00 \\
0,00\end{array}$ & $\begin{array}{l}0,00 \\
0,00\end{array}$ & $\begin{array}{l}3,89 \\
3,39\end{array}$ & 0,20 & $\begin{array}{l}20,11 \\
1237\end{array}$ & poor & & $\begin{array}{l}2,55 \\
2,45\end{array}$ & 作 & 0 & O, 05 & $\begin{array}{l}0,13 \\
0,13\end{array}$ & $\begin{array}{l}0,20 \\
020\end{array}$ & 0,48 \\
\hline P-C2-E10 & $\begin{array}{l}2,50,2,40 \\
2,40 ; 2,30\end{array}$ & $\begin{array}{l}0.800,0.90 \\
0.90: 1.00\end{array}$ & $\begin{array}{l}50,90 \\
13,36\end{array}$ & $\begin{array}{l}2,200 \\
25,73\end{array}$ & $\begin{array}{l}\begin{array}{l}47,31 \\
59,61\end{array} \\
\end{array}$ & 0,000 & $\begin{array}{l}0,00 \\
1,30\end{array}$ & 0,00 & 0,00 & 0,000 & $\begin{array}{l}3,39 \\
3,80\end{array}$ & 0,200 & $\begin{array}{l}12,3 ! \\
8,14\end{array}$ & $\begin{array}{l}\text { close } \\
\text { close }\end{array}$ & & $\begin{array}{l}2,45 \\
2,35\end{array}$ & $\begin{array}{l}-0,044 \\
-1,44\end{array}$ & $\begin{array}{l}0,10 \\
0,10\end{array}$ & 0,05 & 0,13 & 0,200 & $\begin{array}{l}0,48 \\
0,48\end{array}$ \\
\hline P-C2-E11 & 2,$30 ; 2,20$ & $1.00 ; 1.10$ & 15,83 & 10,07 & 73,02 & 0,00 & 1,08 & 0,00 & 0,00 & 0,00 & $\begin{array}{l}4,07 \\
4,07\end{array}$ & 0,20 & 13,37 & close & & 2,25 & $-1,81$ & 0,10 & 0,05 & 0,13 & 0,20 & 0,48 \\
\hline P-C2-E12 & 2,$20 ; 2,10$ & $1.10 ; 1.20$ & 0,00 & 0,00 & 0,00 & 0,00 & 0,00 & 0,00 & 0,00 & 0,00 & $\ldots$ & $\cdots$ & $x^{2}$ & & & 2,15 & . & 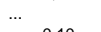 & the & st & wat & $0,0,0$ \\
\hline $\begin{array}{l}2-2-13 \\
2-214\end{array}$ & $\begin{array}{l}2,10 ; 2,00 \\
200 \cdot 190\end{array}$ & $\begin{array}{l}1.20 ; 1.30 \\
1.30 .140\end{array}$ & $\begin{array}{l}9,04 \\
17,95\end{array}$ & 0,56 & $\begin{array}{r}90,40 \\
3846\end{array}$ & 0,00 & 0,00 & 0,00 & 0,00 & 0,00 & $\begin{array}{l}4,45 \\
3,34\end{array}$ & 0,20 & $\begin{array}{l}37,38 \\
2154\end{array}$ & poor & & $\begin{array}{l}2,05 \\
1,05\end{array}$ & $\begin{array}{r}-2,39 \\
139\end{array}$ & 0,10 & 0,05 & 0,13 & 0,20 & 0.48 \\
\hline 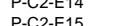 & $\begin{array}{l}2,00 ; 1,90 \\
1,90,180\end{array}$ & $\begin{array}{r}1.30 ; 1.40 \\
1.40 .150\end{array}$ & $\begin{array}{l}17,95 \\
1567\end{array}$ & $\begin{array}{l}42,95 \\
{ }_{1}, 87\end{array}$ & $\begin{array}{l}38,46 \\
88,09\end{array}$ & 0 & 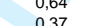 & 0 & 0 & 0 & $\begin{array}{l}3,34 \\
425\end{array}$ & $\begin{array}{l}0,20 \\
020\end{array}$ & $\begin{array}{l}21,54 \\
2634\end{array}$ & $\begin{array}{l}\text { poor } \\
\text { popr }\end{array}$ & & $\begin{array}{l}1,95 \\
1.15\end{array}$ & -1,399 & 0,10 & 0,05 & 0,13 & 0,20 & 0,48 \\
\hline $\begin{array}{l}\text { P.C-E2-E15 } \\
\text { P-C2-E16 }\end{array}$ & $\begin{array}{l}1,90,1,80 \\
1,80 ; 1,70\end{array}$ & $\begin{array}{l}.4041 .50 \\
1.50 .160\end{array}$ & $\begin{array}{l}15,67 \\
870\end{array}$ & $\begin{array}{l}l, 1,8 \\
1,34\end{array}$ & $\begin{array}{l}82,09 \\
89,97\end{array}$ & $\begin{array}{l}0,00 \\
0,00\end{array}$ & 0.00 & $\begin{array}{l}0,00 \\
0,00\end{array}$ & $\begin{array}{l}0,000 \\
0,00\end{array}$ & $0,0,00$ & 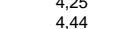 & $\begin{array}{l}0,20 \\
0,20\end{array}$ & $\begin{array}{l}26,34 \\
35,31\end{array}$ & $\begin{array}{l}\text { poor } \\
\text { poor }\end{array}$ & & $\begin{array}{l}1,86 \\
1,75\end{array}$ & $\begin{array}{l}-2,40 \\
-2,69 \\
-2.09\end{array}$ & $\begin{array}{l}0,110 \\
0,10\end{array}$ & $\begin{array}{l}0,005 \\
0,05\end{array}$ & $\begin{array}{l}0,13 \\
0,13\end{array}$ & $\begin{array}{l}0,20 \\
020\end{array}$ & $\begin{array}{l}0,48 \\
0,48\end{array}$ \\
\hline P-C2-E17 & 1,$70 ; 1,60$ & $\begin{array}{l}1.60 ; 1.70 \\
0\end{array}$ & $\begin{array}{l}6,98 \\
6,98\end{array}$ & $\begin{array}{l}0,00 \\
0,00\end{array}$ & $\begin{array}{l}93,02 \\
93,02\end{array}$ & 0 & 0,00 & 0,00 & 0,00 & 0,00 & $\begin{array}{l}4,444 \\
4,51\end{array}$ & o, 0 & 41,22 & poor & & 1,65 & $\begin{array}{l}-2,86 \\
-2,86\end{array}$ & 0,10 & 0,05 & 0,13 & $\begin{array}{l}0,20 \\
0,20\end{array}$ & $\begin{array}{l}0,48 \\
0,48\end{array}$ \\
\hline P-C2-E18 & $\begin{array}{l}1,60 ; 1,50 \\
150,1\end{array}$ & $\begin{array}{l}1.70 ; 1.80 \\
1.10100\end{array}$ & 0,00 & 0,00 & 0,00 & 0,00 & 0,00 & 0,00 & 0,00 & 0,00 & $\cdots$ & $\ldots$ & & $\ldots$ & & 1,55 & & 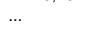 & $\ldots$ & $\cdots$ & $\cdots$ & . \\
\hline $\begin{array}{l}\text { C2-E1919 } \\
\text { C22.20 }\end{array}$ & $\begin{array}{l}1,50 ; 1,40 \\
140.13\end{array}$ & $\begin{array}{l}1.80 ; 1.90 \\
190.200\end{array}$ & $\begin{array}{l}0,00 \\
\end{array}$ & $\begin{array}{l}0,00 \\
33267\end{array}$ & 0,00 & $\begin{array}{l}0,00 \\
0,00\end{array}$ & 00 & 0,00 & 0,00 & 0,00 & $\cdots$ & & 1380 & & & $\begin{array}{r}1,45 \\
1,25\end{array}$ & & $\ldots$ & & & & \\
\hline 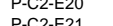 & $\begin{array}{l}1,40 ; 1,30 \\
1,30 \cdot 120\end{array}$ & $\begin{array}{l}1.9002 .200 \\
200 \cdot 210\end{array}$ & $\begin{array}{l}13,33 \\
1,35\end{array}$ & $\begin{array}{l}32,67 \\
155\end{array}$ & $\begin{array}{l}54,00 \\
{ }_{3}\end{array}$ & 0,00 & 0,00 & 0 & O, 00 & 0 & $\begin{array}{l}3,68 \\
\text { ang }\end{array}$ & 0,20 & $\begin{array}{l}13,80 \\
33,18\end{array}$ & $\begin{array}{l}\text { close } \\
\text { lose }\end{array}$ & & $\begin{array}{l}1,35 \\
1,35\end{array}$ & $\begin{array}{l}-2,33 \\
2,313\end{array}$ & 0 & 0,05 & 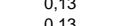 & 0,20 & 0,48 \\
\hline $\begin{array}{l}\text { P-C2-E21 } \\
\text { P-C2-E22 }\end{array}$ & $\begin{array}{l}1,30,1,20 \\
1,20 ; 1,10\end{array}$ & $\begin{array}{l}2.000 ; 2.10 \\
2.102 .20\end{array}$ & $\begin{array}{l}10,85 \\
34,42\end{array}$ & $\begin{array}{r}1,55 \\
40,06\end{array}$ & 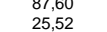 & $\begin{array}{l}0,00 \\
0,00\end{array}$ & $\begin{array}{l}0,00 \\
0,00\end{array}$ & 0.00 & $\begin{array}{l}0,00 \\
0,00\end{array}$ & $0,0,00$ & 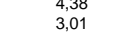 & $\begin{array}{l}0,20 \\
0,20\end{array}$ & $\begin{array}{l}33,18 \\
26,14\end{array}$ & $\begin{array}{l}\text { poor } \\
\text { poor }\end{array}$ & & $\begin{array}{l}\quad, 25 \\
1,15\end{array}$ & $\begin{array}{l}-3,313 \\
-1,85 \\
-12\end{array}$ & $\begin{array}{l}0,10 \\
0,10\end{array}$ & $\begin{array}{l}0,05 \\
0,05\end{array}$ & $\begin{array}{l}0,13 \\
0,13\end{array}$ & $\begin{array}{l}0,20 \\
0,20\end{array}$ & $\begin{array}{l}0,48 \\
0,48\end{array}$ \\
\hline P-C2-E23 & 1,$10 ; 1,00$ & $2.20 ; 2.30$ & 37,11 & 5,84 & 57,04 & 0,00 & , & 0,00 & 0,00 & 0,00 & 3,65 & 0,20 & 17,02 & close & & 1,05 & $-2,59$ & 0,10 & 0,05 & 0,13 & 0,20 & 0,48 \\
\hline 作 & 1,$00 ; 0,90$ & $2.30 ; 2.40$ & 64,67 & 4,67 & 30,33 & 0,00 & 33 & 0,00 & 0,00 & 0,00 & 2,99 & 0,20 & 12,46 & close & & 0,95 & $-2,03$ & 0,10 & 0,05 & 0,13 & 20 & 0,48 \\
\hline $\begin{array}{l}\text { P-C2-E25 } \\
\text { P-C2-E }\end{array}$ & $\begin{array}{l}0,90 ; 0,80 \\
0.80 .07\end{array}$ & $\begin{array}{r}2.40 ; 2.50 \\
250.250\end{array}$ & $\begin{array}{l}60,26 \\
757\end{array}$ & 2,61 & 34,53 & 0,00 & 2. & 0,00 & 0,00 & 0,00 & 310 & 0,20 & 5,85 & close & & 0,85 & $\begin{array}{l}-2,24 \\
2 \geq 1\end{array}$ & 0,10 & 0,05 & 0,13 & 20 & 0,48 \\
\hline $\begin{array}{l}\text { P-C2-E26 } \\
\text { P-C2-E27 }\end{array}$ & $\begin{array}{l}0,80 ; 0 ;, 70 \\
0,70,0,60\end{array}$ & 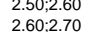 & $\begin{array}{l}7,1,57 \\
67,01\end{array}$ & $\begin{array}{l}1,00 \\
0,34\end{array}$ & $\begin{array}{l}26,42 \\
32,31\end{array}$ & $\begin{array}{l}0,00 \\
0,00\end{array}$ & 0 & 0,00 & 0,00 & 0,00 & 302 & $\begin{array}{l}0,20 \\
020\end{array}$ & $\begin{array}{l}12,11 \\
1285\end{array}$ & $\begin{array}{l}\text { close } \\
\text { cose }\end{array}$ & & 0.65 & $\begin{array}{l}-2,13 \\
-237 \\
-237\end{array}$ & 010 & 005 & 0,13 & 20 & 48 \\
\hline P-C2-E28 & 0,$60 ; 0,50$ & $\begin{array}{l}2.000 .2 .10 \\
2.70 ; 2.80\end{array}$ & 59,09 & 5,19 & $\begin{array}{l}3<,, 11 \\
34,74\end{array}$ & 0 & 0,65 & 0,00 & 0,32 & 0.00 & $\begin{array}{l}3,02 \\
3,05\end{array}$ & 0 & $\begin{array}{l}\begin{array}{l}21,85 \\
11,47\end{array} \\
1\end{array}$ & $\begin{array}{l}\text { close } \\
\text { close }\end{array}$ & & 0.55 & -2.50 & 0,10 & 0.05 & 0,13 & $\begin{array}{l}0,20 \\
0,20\end{array}$ & 48 \\
\hline P-C2-Е29 & 0,$50 ; 0,40$ & $\begin{array}{l}2.10,2.000 \\
2.80 ; .90\end{array}$ & $\begin{array}{l}534,55 \\
54,\end{array}$ & 2,60 & 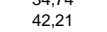 & 0,32 & 0 & 0,00 & 0 & 0,00 & 3,30 & $\begin{array}{l}0,20 \\
0,20\end{array}$ & 11,82 & $\begin{array}{l}\text { close } \\
\text { close }\end{array}$ & & 0,45 & $\begin{array}{l}-2,20 \\
-2,85\end{array}$ & 0,10 & 0,05 & 0,13 & 0,20 & $\begin{array}{l}0,48 \\
0,48\end{array}$ \\
\hline P-C2-E30 & 0,$40 ; 0,30$ & $2.90 ; 3.00$ & 60,26 & 1,99 & 36,42 & 0,00 & 1, & 0,00 & 0,00 & 0,00 & 3,13 & 0,20 & 8,34 & close & & 0,35 & $\begin{array}{l}-2,78 \\
-178\end{array}$ & 0,10 & 0,05 & 0,13 & 0,20 & 0,48 \\
\hline $\begin{array}{l}\text { P-C2-E2 } \\
\text { P-C2-E32 }\end{array}$ & $\begin{array}{l}0,20 ; 0,10 \\
0,10,0.00\end{array}$ &  & $\begin{array}{l}15,41 \\
50,81\end{array}$ & $\begin{array}{l}1,4 \\
2.6\end{array}$ & $\begin{array}{l}82,80 \\
46,25\end{array}$ & $\begin{array}{l}0,00 \\
0,33\end{array}$ & & $\begin{array}{l}0,00 \\
0,00\end{array}$ & 0, & 00 & $\begin{array}{l}4,22 \\
3,40\end{array}$ & 0.20 & $\begin{array}{l}28,88 \\
13,93\end{array}$ & $\begin{array}{l}\text { poor } \\
\text { close }\end{array}$ & & 0.05 & -335 & 0 & 000 & 0.13 & 0,200 & 18 \\
\hline P-C2-E34 & 0,$00 ;-0,10$ & $\begin{array}{l}3.30 ; 3.3 .30 \\
3.30\end{array}$ & $\begin{array}{l}60,01 \\
65,15\end{array}$ & 2,93 & $\begin{array}{l}46,25 \\
30,94\end{array}$ & $\begin{array}{l}0,33 \\
0,00\end{array}$ & & 0 & 0,00 & 0,00 & $\begin{array}{l}3,40 \\
3,00\end{array}$ & 0,20 & 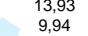 & $\begin{array}{l}\text { close } \\
\text { close }\end{array}$ & & -0 & -3.05 & 0,10 & 0.05 & 0,13 & $\begin{array}{l}0,20 \\
0,20\end{array}$ & 0.48 \\
\hline P-C2-E35 & $-0,10 ;-0,20$ & $\begin{array}{l}3.300 .30 .40 \\
3.40 .350\end{array}$ & 52,88 & $\begin{array}{l}3,0 \\
3,73\end{array}$ & $\begin{array}{r}30,94 \\
42,03\end{array}$ & 0,68 & , & 0,00 & 0,0 & 0,00 & 3,34 & $\begin{array}{l}0,20 \\
0,20\end{array}$ & 11,65 & close & $500 \pm 60$ & $\begin{array}{l}-0,15 \\
-0\end{array}$ & $\begin{array}{l}-, 3,49 \\
-3.40\end{array}$ & & 0, & 0,13 & 0 & $\begin{array}{l}0,48 \\
0,48\end{array}$ \\
\hline P-C2-E36 & $-0,20 ;-0,30$ & $3.50 ; 3.360$ & 40,60 & 38 & 54,03 & 0,34 & & 0,00 & 0, & 0,00 & 3,61 & 0,20 & 14,35 & close & 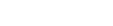 & $-0,25$ & $-3,36$ & 0, & 0,05 & 0,13 & 0,20 & 18 \\
\hline P-C2-E37 & $-0,30$ & 3.60; & 11,15 & $29, \mathrm{C}$ & 5 & 0, & & 0, & 0, & & 3,61 & 0 & 8,67 & close & & -0 & -3 & & $0, \mathrm{C}$ & 13 & 0,20 & 18 \\
\hline $\begin{array}{l}\text { P-C2-E-E38 } \\
\text { P-C2-339 }\end{array}$ & $\begin{array}{l}-0,4 \\
-0,5\end{array}$ & $\begin{array}{l}3.7 \\
3.8\end{array}$ & $\begin{array}{l}63 \\
63\end{array}$ & $\begin{array}{l}4,4 \\
5, \\
\end{array}$ & $\begin{array}{l}32,08 \\
26\end{array}$ & 065 & 0, & 0, & - & 0,00 & $\begin{array}{l}3,03 \\
2,99\end{array}$ & 0 & 56 & $\begin{array}{l}\text { close } \\
\text { cloes }\end{array}$ & & & $\begin{array}{l}-3,48 \\
-354\end{array}$ & 0,10 & 0 & 013 & ,20 & 18 \\
\hline P-C2-E40 & $\begin{array}{l}-0,50,-0 \\
-0,060=0\end{array}$ & $\begin{array}{l}.38 ; \\
3.90 ;\end{array}$ & & $\begin{array}{l}5,1 \\
1,2\end{array}$ & & & & & & & & $\begin{array}{l}0,20 \\
0,20\end{array}$ & $\begin{array}{l}\text {, } \\
7,7\end{array}$ & $\begin{array}{l}\text { close } \\
\text { close }\end{array}$ & & & & & & & 20 & 18 \\
\hline P-C2-E41 & $\begin{array}{l}-0,7 \\
-0,7\end{array}$ & $\begin{array}{l}5.500 .4 .00 \\
4.00 ; 4.10\end{array}$ & 5 & , & 4, & 1,2 & 2 & 0,6 & , & 0, & 3,5 & $0,0 v$ & , & close & & & -4 & & & , & ${ }_{20}^{20}$ & 18 \\
\hline P-C2-E42 & $-0,80 ; 0,90$ & $4.10 ; 4.20$ & 51,22 & 5, & 42 & 0, & & 0, & 0, & 0,00 & 3 & 0,20 & 12 & close & 4280 & -0 & $-4,18$ & & 0, & 0, & 0,20 & 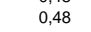 \\
\hline P-C2-E43 & $-0,90 ;-1,00$ & 4.2 & 31,25 & 17 & 50 & 0, & 0,78 & 0 & 0,00 & 0,00 & 3,5 & 0, & 16,50 & close & & -0 & $-4,48$ & & 0,05 & 0,13 & 20 & 48 \\
\hline $\begin{array}{l}\text { P-C2-E444 } \\
\text { P-C2-445 }\end{array}$ & $\begin{array}{l}-1,0 \\
11\end{array}$ & $\begin{array}{l}4.30 ; 4.40 \\
440.450\end{array}$ & & & & & & & & & & 0 & 10 & close & & & -4 & & & 13 & 0,20 & 18 \\
\hline 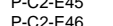 & & & & & & & & 0 & & & & 0 & & $\begin{array}{l}\text { close } \\
\text { cloge }\end{array}$ & & -1 & $-4,5$ & & & & & 18 \\
\hline $\begin{array}{l}\text { EEt6 } \\
\text { E47 }\end{array}$ & $\begin{array}{l}-1,2 \\
-1,3\end{array}$ & $\begin{array}{l}\begin{array}{r}.500 .4 .60 \\
4.60: 4.70\end{array} \\
4\end{array}$ & $\begin{array}{l}\begin{array}{l}42,12 \\
9,94\end{array} \\
\text { a }\end{array}$ & $\begin{array}{l}18 \\
53\end{array}$ & $\begin{array}{l}26,21 \\
16,35\end{array}$ & $\begin{array}{l}8, \\
15,\end{array}$ & $\begin{array}{l}3,88 \\
5,45\end{array}$ & $\begin{array}{l}0,0 \\
0,0\end{array}$ & 0,6 & $0, c$ & 3, & $\begin{array}{l}0,20 \\
0,20\end{array}$ & $\begin{array}{l}\begin{array}{l}14,50 \\
22,50\end{array} \\
2\end{array}$ & $\begin{array}{l}\text { close } \\
\text { poor }\end{array}$ & & $\begin{array}{l}-1, \\
-1 \\
-1 .\end{array}$ & -5, & & & 0,13 & $\begin{array}{l}0,20 \\
0,20\end{array}$ & 18 \\
\hline P-C2-E48 & $-1,40 ;-1,50$ & 4.7 & 9, & & 62 & 0, & & 0,0 & 0, & 0,0 & 3,8 & $\begin{array}{l}0,20 \\
0,20\end{array}$ & 12,51 & close & $4640 \pm 60$ & $-1,45$ & -5, & 0, & 0, & 0 & 0,20 & 18 \\
\hline P-C2-E49 & $\begin{array}{l}-1,50 ;-1,60 \\
-1,1,10\end{array}$ & $\begin{array}{r}4.807 .4 .90 \\
4.00 .500\end{array}$ & $\begin{array}{l}13,85 \\
13,85\end{array}$ & 57 & $\begin{array}{l}27,36 \\
1920\end{array}$ & 0,00 & $\begin{array}{l}1,01 \\
0,01\end{array}$ & 0, & 0,0 & 0,00 & 3, & 0,20 & $\begin{array}{l}17,84 \\
0,54\end{array}$ & $\begin{array}{l}\text { close } \\
\text { los }\end{array}$ & & $-1,5$ & -4, & 0,1 & 0, & 0, & 0,20 & 48 \\
\hline $\begin{array}{l}\text { P-C2-E50 } \\
\text { P-C2-551 }\end{array}$ & $\begin{array}{r}-1,60 ;-1,70 \\
170,180\end{array}$ & $\begin{array}{r}4.90 ; 5.500 \\
550.510\end{array}$ & 3.21 & 7536 & 1964 & 1.07 & & 0.00 & & 0,00 & & 0.20 & $\begin{array}{r}21,54 \\
21,01\end{array}$ & $\begin{array}{l}\text { poor } \\
\text { poor }\end{array}$ & & & $\begin{array}{r}-4,63 \\
-486\end{array}$ & & & & 20 & 0,48 \\
\hline P-CZ2-EST & $-1, /(2 ; 1,80$ & $5.00 ; 5.10$ & 3,21 & 15,36 & 19,64 & 1,07 & $0, / 1$ & 0,00 & 0,00 & 0,00 & 3,11 & 0,20 & 21,01 & poor & $4775 \pm 60$ & $-1,15$ & $-4,86$ & & 0,05 & 0,13 & 0,20 & 0,48 \\
\hline
\end{tabular}


Table S3. Relative total (dead and alive) abundances of foraminifera taxa found within the samples collected from the core T-C2 (Troaon saltmarsh, bay of Brest).

\begin{tabular}{|c|c|c|c|c|c|c|c|c|c|c|c|c|c|c|c|c|c|c|c|c|c|c|}
\hline Sample code & $\begin{array}{l}\text { Elevation (m } \\
\text { NGF) }\end{array}$ & Depth (m) & $\begin{array}{l}\text { Jadammina } \\
\text { macrescens }\end{array}$ & $\begin{array}{l}\text { Haplophragm } \\
\text { oides wiberti }\end{array}$ & $\begin{array}{c}\text { Trochammina } \\
\text { inflatata }\end{array}$ & $\begin{array}{c}\text { Arenoparalla } \\
\text { mexicana }\end{array}$ & $\begin{array}{c}\text { Miliammina } \\
\text { fusca }\end{array}$ & $\begin{array}{l}\text { Haynesina } \\
\text { germanica }\end{array}$ & Elphidium sp. & Ammonia sp. & $\begin{array}{l}\text { Palaeomarsh } \\
\text { elevation (m) from } \\
\text { WA-PLS Model } \\
\text { comp } 3\end{array}$ & $\operatorname{RMSEP}(\mathrm{m})$ & MinDC & $\begin{array}{c}\text { MAT } \\
\text { diagnostic }\end{array}$ & 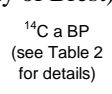 & $\begin{array}{l}\text { mid sample } \\
\text { elevation }\end{array}$ & RSL (m) & $\begin{array}{c}\text { surface } \\
\text { sampling } \\
\text { error }\end{array}$ & $\begin{array}{l}\text { core } \\
\text { sampling } \\
\text { error }\end{array}$ & $\begin{array}{c}\text { Elevation } \\
\text { error } \\
\text { (benchmark } \\
\text { \& DGPS) }\end{array}$ & RMSEP (m) & $\begin{array}{l}\text { Total error } \\
(\mathrm{m})\end{array}$ \\
\hline C2-E01 & $\begin{array}{l}3,40 ; 3,30 \\
\text {, }\end{array}$ & 0,$00 ; 0,10$ & 7,42 & 49,03 & 24,84 & 0,32 & 18,39 & 0,00 & 0,00 & 0,00 & $\begin{array}{l}3,18 \\
3,18\end{array}$ & 0,20 & 0,27 & good & & 3,35 & 0,17 & 0,10 & 0,05 & 0,13 & 0,20 & 0,48 \\
\hline $20-2$ & $\begin{array}{l}3,30 ; 3,20 \\
320,3,1\end{array}$ & $\begin{array}{l}0,10 ; 0,20 \\
0\end{array}$ & & $\begin{array}{l}2,30 \\
258\end{array}$ & $\begin{array}{l}24,34 \\
3161\end{array}$ & $\begin{array}{l}0,00 \\
0,00\end{array}$ & $\begin{array}{l}34,87 \\
1806\end{array}$ & $\begin{array}{l}0,00 \\
0,00\end{array}$ & $\begin{array}{l}0,00 \\
000\end{array}$ & 0,00 & $\begin{array}{l}3,05 \\
3,12\end{array}$ & $\begin{array}{l}0,20 \\
020\end{array}$ & $\begin{array}{l}13,81 \\
207\end{array}$ & close & & 3, & 00 & 010 & 005 & 13 & 20 & 0,48 \\
\hline c2- & 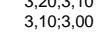 & $\begin{array}{l}0,20,0,30 \\
0,30 ; 0,40\end{array}$ & $\begin{array}{l}44,1 / 4 \\
59,87\end{array}$ & 8,41 & $\begin{array}{l}13,01 \\
28,80\end{array}$ & $\begin{array}{l}0,005 \\
0,65\end{array}$ & $\begin{array}{l}2,27 \\
2,27\end{array}$ & $\begin{array}{l}0,00 \\
0,00\end{array}$ & $\begin{array}{l}0,00 \\
0,00\end{array}$ & $\begin{array}{l}0,00 \\
0,00\end{array}$ & $\begin{array}{l}3,12 \\
3,04\end{array}$ & $\begin{array}{l}0,20 \\
0,20\end{array}$ & $\begin{array}{l}2,07 \\
9,39\end{array}$ & $\begin{array}{l}\text { good } \\
\text { close }\end{array}$ & & $\begin{array}{l}3,105 \\
3,05\end{array}$ & 0 & 0 & $\begin{array}{l}0,05 \\
0,05\end{array}$ & 0,13 & 20 & $\begin{array}{l}0,48 \\
0,48\end{array}$ \\
\hline $0<-200$ & 3,$00 ; 2,90$ & & 58,86 & 2,85 & $\begin{array}{l}3,54 \\
3,54\end{array}$ & 0,63 & 4,11 & 0,00 & & 0,000 & & & 4,31 & & & & & 0,10 & 0,05 & 0,13 & 20 & $\begin{array}{l}0,40 \\
0,48\end{array}$ \\
\hline C2-E06 & $\begin{array}{l}2,0,2,2,80 \\
2,90 ; 20\end{array}$ & 0,$50 ; 0,60$ & $\begin{array}{l}00,00 \\
67,08\end{array}$ & $\begin{array}{l}2,000 \\
2,80\end{array}$ & $\begin{array}{l}25,78 \\
25,78\end{array}$ & $\begin{array}{l}0,00 \\
0,00\end{array}$ & $\begin{array}{l}4,35 \\
4,35\end{array}$ & $\begin{array}{l}0,00 \\
0,00\end{array}$ & $\begin{array}{l}0,00 \\
0,00\end{array}$ & 0,00 & $\begin{array}{l}\quad, 1,14 \\
2,89\end{array}$ & 0,20 & $\begin{array}{l}5,51 \\
5,52\end{array}$ & close & & $\begin{array}{l}2,85 \\
2.85\end{array}$ & $\begin{array}{l}-0.04 \\
-0.04\end{array}$ & 0,10 & $\begin{array}{l}0,05 \\
0,05\end{array}$ & 0,13 & 0.20 & $\begin{array}{l}0,48 \\
0,48\end{array}$ \\
\hline r-C2-E07 & $\begin{array}{l}2,80 ; 2,70 \\
, 72,70\end{array}$ & $\begin{array}{l}0,60 ; 0,70 \\
0\end{array}$ & 54,97 & $\begin{array}{l}2,32 \\
2,320\end{array}$ & $\begin{array}{l}39,74 \\
3\end{array}$ & 0,00 & $\begin{array}{l}2,98 \\
\end{array}$ & 0,00 & 0,00 & 0,00 & 3,23 & 0,20 & 5,44 & close & $940 \pm 56$ & 2,75 & $-0,48$ & 0,10 & 0,05 & 0,13 & 0,20 & 0,48 \\
\hline $\begin{array}{l}\text { C2-E08 } \\
\text { C2-E09 }\end{array}$ & $\begin{array}{l}2,70 ; 2,60 \\
\end{array}$ & $\begin{array}{l}0,70 ; 0,80 \\
0\end{array}$ & $\begin{array}{l}64,57 \\
667\end{array}$ & $\begin{array}{l}2,32 \\
332\end{array}$ & $\begin{array}{l}32,78 \\
2203\end{array}$ & 0,00 & 0,33 & 0,00 & 0,00 & 0,00 & $\begin{array}{l}3,04 \\
0,05\end{array}$ & 0,20 & $\begin{array}{l}11,27 \\
\end{array}$ & close & & $\begin{array}{l}2,65 \\
255\end{array}$ & $-0,39$ & 0,10 & 0,05 & 0,13 & 0,20 & 0,48 \\
\hline $\begin{array}{l}\text { C. C2-E99 } \\
\text { C2-E10 }\end{array}$ & $\begin{array}{l}\text {, } 2,60 ; 2,50 \\
2,50 ; 2,40\end{array}$ & $\begin{array}{l}0,80 ; 0 ;, 90 \\
0,90 ; 1,00\end{array}$ & $\begin{array}{l}66,77 \\
44,37\end{array}$ & $\begin{array}{l}3,23 \\
0,66\end{array}$ & $\begin{array}{l}29,03 \\
54,30\end{array}$ & $\begin{array}{l}0,00 \\
0,00\end{array}$ & $\begin{array}{l}0,97 \\
0,66\end{array}$ & $\begin{array}{l}00 \\
00 \\
0\end{array}$ & $\begin{array}{l}0,00 \\
0,00\end{array}$ & $\begin{array}{l}0,00 \\
0.00\end{array}$ & $\begin{array}{l}2,95 \\
3,56\end{array}$ & $\begin{array}{l}0,20 \\
0.20\end{array}$ & $\begin{array}{l}10,57 \\
16,14\end{array}$ & $\begin{array}{l}\text { close } \\
\text { close }\end{array}$ & & $\begin{array}{l}2,55 \\
2,45\end{array}$ & $\begin{array}{l}-0,40 \\
-1,11\end{array}$ & $\begin{array}{l}0,10 \\
010\end{array}$ & $\begin{array}{l}0,05 \\
0.05\end{array}$ & 0,13 & 0,20 & $\begin{array}{l}0,48 \\
0,48\end{array}$ \\
\hline & 2,$50 ; 2,40$ & $\begin{array}{l}0,90 ; ;, 00 \\
1,00 ; 1,10\end{array}$ & 44,37 & 0,66 & 54,30 & 0,00 & 0,66 & 0,00 & 0,00 & $\begin{array}{l}0,000 \\
0.00\end{array}$ & 3,56 & $\begin{array}{l}0,20 \\
0.20\end{array}$ & $\begin{array}{l}16,14 \\
10,36\end{array}$ & $\begin{array}{l}\text { close } \\
\text { close }\end{array}$ & & $\begin{array}{l}2,45 \\
2,35\end{array}$ & $\begin{array}{l}-1,11 \\
-0.83\end{array}$ & 0,10 & $\begin{array}{l}0,05 \\
0,05\end{array}$ & $\begin{array}{l}0,13 \\
0,13\end{array}$ & $\begin{array}{l}0,20 \\
0.20\end{array}$ & $\begin{array}{l}0,48 \\
0,48\end{array}$ \\
\hline C2-E12 & $\begin{array}{l}2,4,40,2,20 \\
2,20 ; 20\end{array}$ & 1,$10 ; 1,20$ & $\begin{array}{l}35,45 \\
46,84\end{array}$ & $\begin{array}{l}2,260 \\
2,33\end{array}$ & 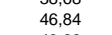 & $\begin{array}{l}0,66 \\
0,66\end{array}$ & $\begin{array}{l}\text {, } \\
3,32\end{array}$ & 0,00 & 0,00 & 0,00 & $\begin{array}{l}\text {, } 10 \\
3,47\end{array}$ & $\begin{array}{l}0,20 \\
0,20\end{array}$ & $\begin{array}{l}7,8,86 \\
0\end{array}$ & $\begin{array}{l}\text { close } \\
\text { close }\end{array}$ & & $\begin{array}{l}2,25 \\
2,25\end{array}$ & -1,22 & 0,10 & $\begin{array}{l}0,05 \\
0,05\end{array}$ & $\begin{array}{l}0,13 \\
0,13\end{array}$ & $\begin{array}{l}0,20 \\
0,20\end{array}$ & $\begin{array}{l}0,40 \\
0,48\end{array}$ \\
\hline r-C2-E13 & 2,$20 ; 2,10$ & 1,$20 ; 1,30$ & 54,19 & 1,61 & 43,23 & 0,00 & 0,97 & 0,00 & 0,00 & 0,00 & 3,30 & 0,20 & 10,04 & close & & 2,15 & $-1,15$ & 0,10 & 0,05 & 0,13 & 0,20 & 0,48 \\
\hline $\begin{array}{l}\text { C2-E14 } \\
\text { C2-E15 }\end{array}$ & $\begin{array}{l}2,10 ; 2,00 \\
2\end{array}$ & $\begin{array}{l}1,30 ; 1,40 \\
1,40\end{array}$ & $\begin{array}{l}55,81 \\
5502\end{array}$ & $\begin{array}{l}2,83 \\
356\end{array}$ & $\begin{array}{l}41,36 \\
4414\end{array}$ & 0,00 & 0,00 & 0,00 & 0,00 & 0,00 & $\begin{array}{l}3,25 \\
325\end{array}$ & 0,20 & 12,35 & close & & $\begin{array}{l}2,05 \\
2,05\end{array}$ & $-1,20$ & 0,10 & 0,05 & 0,13 & 0,20 & 0,48 \\
\hline 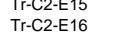 & $\begin{array}{l}2,00 ; 1,90 \\
1,90 ; 1,80\end{array}$ & $\begin{array}{l}1,40 ; ;, 50 \\
1,50 ; 1,60\end{array}$ & $\begin{array}{l}55,02 \\
6,509\end{array}$ & $\begin{array}{l}3,56 \\
10.69\end{array}$ & $\begin{array}{l}41,42 \\
21,170\end{array}$ & $\begin{array}{l}0,00 \\
0,00\end{array}$ & $\begin{array}{l}0,00 \\
2.52\end{array}$ & $\begin{array}{l}00 \\
00 \\
0\end{array}$ & $\begin{array}{l}0,00 \\
0,00\end{array}$ & 0,00 & $\begin{array}{l}3,25 \\
2,81\end{array}$ & 0,20 & $\begin{array}{l}12,64 \\
10,35\end{array}$ & $\begin{array}{l}\text { close } \\
\text { close }\end{array}$ & & $\begin{array}{l}1,95 \\
1,5\end{array}$ & $\begin{array}{r}-1,30 \\
-0.96\end{array}$ & $\begin{array}{l}0,10 \\
010\end{array}$ & $\begin{array}{l}0,05 \\
0.05\end{array}$ & 0,13 & 0,20 & $\begin{array}{l}0,48 \\
0,48\end{array}$ \\
\hline C2-E17 & $\begin{array}{l}1,9 ; 0 ; 1,80 \\
1,88 ; 1,70\end{array}$ & $\begin{array}{l}1,50 ; ; 1,60 \\
1,60 ; 1,70\end{array}$ & $\begin{array}{l}65,09 \\
49,35\end{array}$ & 10,69 & 21,70 & $\begin{array}{l}0,00 \\
0,00\end{array}$ & $\begin{array}{l}2,52 \\
0.00\end{array}$ & 0,00 & $\begin{array}{l}0,00 \\
0,00\end{array}$ & $\begin{array}{l}0,00 \\
0.00\end{array}$ & $\begin{array}{l}2,81 \\
3,39\end{array}$ & $\begin{array}{l}0,20 \\
0.20\end{array}$ & $\begin{array}{l}10,35 \\
14.34\end{array}$ & $\begin{array}{l}\text { close } \\
\text { close }\end{array}$ & & 1,85 & $\begin{array}{l}-0,96 \\
-1.64\end{array}$ & $\begin{array}{l}0,10 \\
0,10\end{array}$ & $\begin{array}{l}0,055 \\
0,05\end{array}$ & 0,13 & $\begin{array}{l}0,20 \\
0,20\end{array}$ & $\begin{array}{l}0,48 \\
0,48\end{array}$ \\
\hline C2-E18 & $\begin{array}{l}1,80 ; 1,60 \\
1,70 ; 1\end{array}$ & $\begin{array}{l}1,00,70 ; 1,80 \\
\end{array}$ & 39,09 & $\begin{array}{l}2,93 \\
2,93\end{array}$ & $\begin{array}{l}44,06 \\
46,91\end{array}$ & $\begin{array}{l}0,00 \\
0,00\end{array}$ & $\begin{array}{l}11,07 \\
11,07\end{array}$ & 0,00 & $\begin{array}{l}0,00 \\
0,00\end{array}$ & 0 & 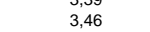 & $\begin{array}{l}0,20 \\
0,20\end{array}$ & $\begin{array}{l}4,2,27 \\
4,27\end{array}$ & $\begin{array}{l}\text { colose } \\
\text { close }\end{array}$ & & $\begin{array}{l}1,15 \\
1,65\end{array}$ & $\begin{array}{l}-1,04 \\
-1,81\end{array}$ & 0,10 & $\begin{array}{l}0,05 \\
0,05\end{array}$ & 0,13 & 0,20 & $\begin{array}{l}0,48 \\
0,48\end{array}$ \\
\hline C2-E19 & 1,$60 ; 1,50$ & 1,$80 ; 1,90$ & 62,74 & 2,55 & 34,71 & 0,00 & 0,00 & 0,00 & 0,00 & 0,00 & 3,09 & 0,20 & 12,02 & close & & 1,55 & $-1,54$ & 0,10 & 0,05 & 0,13 & 0,20 & 0,48 \\
\hline C2-E20 & 1,$50 ;$ & $\begin{array}{l}1,90 ; 2,00 \\
2\end{array}$ & 56,35 & 0.00 & & 0 & 1,55 & 1,55 & 0,62 & & 2,94 & 0,20 & $\begin{array}{l}12,19 \\
\end{array}$ & close & & 45 & $-1,49$ & 10 & 0,05 & 0,13 & 20 & 0,48 \\
\hline $\begin{array}{l}\text { C-E2-E21 } \\
\text { C2-E22 }\end{array}$ & $\begin{array}{l}1,40 ; 1,30 \\
1,301,20\end{array}$ & $\begin{array}{l}2,00 ; 2,10 \\
2,10 ; 2,20\end{array}$ & $\begin{array}{l}59,03 \\
50,49\end{array}$ & $\begin{array}{l}0,00 \\
0,05\end{array}$ & $\begin{array}{l}39,68 \\
44,63\end{array}$ & $\begin{array}{l}0,00 \\
0,00\end{array}$ & $\begin{array}{l}0,00 \\
0,00\end{array}$ & $\begin{array}{l}1,29 \\
2,61\end{array}$ & $\begin{array}{l}0,00 \\
0,08\end{array}$ & 0,00 & $\begin{array}{l}3,05 \\
2,84\end{array}$ & 0,20 & $\begin{array}{l}15,35 \\
1165\end{array}$ & close & & $\begin{array}{l}1,35 \\
1,25\end{array}$ & $\begin{array}{r}-1,70 \\
-159\end{array}$ & 0,10 & $\begin{array}{l}0,05 \\
0,05\end{array}$ & 0,13 & 0,20 & 0,48 \\
\hline $\begin{array}{l}-C 2-E 22 \\
-C 2-E 23\end{array}$ & $\begin{array}{l}1,3 ;, 1,20 \\
1,20 ; 1,10\end{array}$ & $\begin{array}{l}2,10,2,20 \\
2,20 ; 2,30\end{array}$ & $\begin{array}{l}50,49 \\
5,246\end{array}$ & $\begin{array}{l}0,65 \\
0,00\end{array}$ & $\begin{array}{l}44,63 \\
44,06\end{array}$ & $\begin{array}{l}0,00 \\
0,00\end{array}$ & $\begin{array}{l}0,00 \\
1.45\end{array}$ & $\begin{array}{l}2,0,01 \\
0.00\end{array}$ & $\begin{array}{l}., 98 \\
2.03\end{array}$ & 0.00 & $\begin{array}{l}2,384 \\
3,01\end{array}$ & $\begin{array}{l}0,20 \\
0.20\end{array}$ & $\begin{array}{l}77,65 \\
13,15\end{array}$ & $\begin{array}{l}\text { close } \\
\text { close }\end{array}$ & & $\begin{array}{l}, 2,25 \\
1,15\end{array}$ & $\begin{array}{l}-1,59 \\
-1,86\end{array}$ & $\begin{array}{l}0,10 \\
0,10\end{array}$ & 0.05 & $\begin{array}{l}0,13 \\
0,13\end{array}$ & 20 & $\begin{array}{l}0,48 \\
0,48\end{array}$ \\
\hline r-C2-E24 & 1,$10 ; 1,00$ & $\begin{array}{l}<, 20,2,30 \\
2,30 ; 2,40\end{array}$ & $\begin{array}{l}22,46 \\
17,19\end{array}$ & $\begin{array}{l}0,31 \\
0,00\end{array}$ & $\begin{array}{l}43,000 \\
73,75\end{array}$ & $\begin{array}{l}0,00 \\
0,00\end{array}$ & $\begin{array}{l}1,49 \\
6,25\end{array}$ & $\begin{array}{l}0,000 \\
1,25\end{array}$ & $\begin{array}{l}2,25 \\
1,25\end{array}$ & $\begin{array}{l}0,00 \\
0,00\end{array}$ & $\begin{array}{l}3,01 \\
3,74\end{array}$ & $\begin{array}{l}0,20 \\
0,20\end{array}$ & $\begin{array}{l}15,15 \\
17,74\end{array}$ & $\begin{array}{l}\text { colose } \\
\text { close }\end{array}$ & & $\begin{array}{l}1,105 \\
1,05\end{array}$ & $\begin{array}{l}-1,06 \\
-2,69\end{array}$ & 0,10 & $\begin{array}{l}0,05 \\
0,05\end{array}$ & 0,13 & $\begin{array}{l}0,20 \\
0,20\end{array}$ & $\begin{array}{l}0,48 \\
0,48\end{array}$ \\
\hline C2-E25 & 1,$00 ; 0,90$ & 2,$40 ; 2,50$ & 57,19 & 2,81 & 33,75 & 0,00 & 5,63 & 00 & 0,63 & 0,00 & 3,00 & 0,20 & 2,74 & good & & 0,95 & $-2,05$ & 0,10 & 0,05 & 0,13 & 20 & 0,48 \\
\hline r-C2-E26 & $\begin{array}{l}0,90 ; 0,80 \\
\end{array}$ & $\begin{array}{l}2,50 ; 2,60 \\
\end{array}$ & 58,25 & 4,21 & & & 4, & 20 & 0,00 & 0,00 & D & 0,20 & 4,17 & close & & 0,85 & $-2,23$ & in & 0,05 & 1 & 20 & 0,48 \\
\hline $\begin{array}{l}\text { C2-E27 } \\
\text { C2-E28 }\end{array}$ & $\begin{array}{l}0,80 ; 0,70 \\
0,70.060\end{array}$ & $\begin{array}{l}2,60 ; 2,70 \\
270 \cdot 280\end{array}$ & $\begin{array}{l}45,45 \\
2627\end{array}$ & $\begin{array}{l}3,03 \\
0,32\end{array}$ & $\begin{array}{l}40,00 \\
2753\end{array}$ & 0.00 & $\begin{array}{l}3,64 \\
728\end{array}$ & 1203 & $\begin{array}{l}4,55 \\
2627\end{array}$ & 0.32 & $\begin{array}{l}2,16 \\
-049\end{array}$ & 0,20 & $\begin{array}{l}12,77 \\
3327\end{array}$ & close & & 0 & $-1,41$ & 10 & &, 13 & 20 & 0,48 \\
\hline $\begin{array}{l}\mathrm{r}-\mathrm{T}-2-\mathrm{-}-28 \mathrm{C} \\
\mathrm{Tr}-\mathrm{E}\end{array}$ & $\begin{array}{l}0,0,0,0,60 \\
0,60 ; 0,50\end{array}$ & $\begin{array}{l}2,1,8 ; \\
2,80 ;\end{array}$ & $\begin{array}{l}22,621 \\
34,98\end{array}$ & $\begin{array}{l}u_{4,32} \\
4,93\end{array}$ & & & $\begin{array}{r}7,28 \\
21,08\end{array}$ & $\begin{array}{l}\begin{array}{l}2,, 03 \\
0.45\end{array} \\
0.5\end{array}$ & $\begin{array}{c}26,27 \\
0,00\end{array}$ & $0,3 \quad$, & $\begin{array}{l}-0,49 \\
3,27\end{array}$ & $\begin{array}{l}0,20 \\
0,20\end{array}$ & $\begin{array}{r}32,27 \\
4,96\end{array}$ & $\begin{array}{l}\text { poor } \\
\text { close }\end{array}$ & & 0.55 & $\begin{array}{l}1, \\
-2\end{array}$ & 0.10 & 0,05 & 0,13 & 20 & $\begin{array}{l}0,48 \\
0,48\end{array}$ \\
\hline Tr-C2-E30 & 0 & $\begin{array}{l}2,80,2,2,00 \\
2,90 ; 3,00\end{array}$ & $\begin{array}{l}38,48 \\
38,59\end{array}$ & 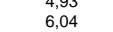 & $\begin{array}{l}37,51 \\
47,65\end{array}$ & $\begin{array}{l}0,00 \\
0,00\end{array}$ & $\begin{array}{l}2,1,08 \\
2,68\end{array}$ & 3 & $\begin{array}{l}0,00 \\
1,68\end{array}$ & 0 & $\begin{array}{l}3,21 \\
2,79\end{array}$ & $\begin{array}{l}0,20 \\
0,20\end{array}$ & $\begin{array}{l}4,96 \\
15,54\end{array}$ & $\begin{array}{l}\text { colose } \\
\text { close }\end{array}$ & & $\begin{array}{l}0,55 \\
0,45\end{array}$ & $\begin{array}{l}-2,12 \\
-2,34\end{array}$ & $\begin{array}{l}0,10 \\
0,10\end{array}$ & $\begin{array}{l}0,05 \\
0,05\end{array}$ & $\begin{array}{l}0,13 \\
0,13\end{array}$ & $\begin{array}{l}0,20 \\
0,20\end{array}$ & $\begin{array}{l}0,48 \\
0,48\end{array}$ \\
\hline Tr-C2-E31 & 0,$40 ; 0,30$ & 3,$00 ; 3,10$ & 38,80 & 8,20 & 46,69 & 0 & 2,21 & & 3,15 & $0,0 \mathrm{z}$ & 2,83 & 0,20 & 11,78 & close & & 0, & $-2,48$ & 0,10 & 0,05 & 0,13 & 20 & 0,48 \\
\hline Tr-C2-E32 & 0,$30 ; 0,20$ & 3,$10 ; 3,20$ & 26 & 1,61 & 41, & 0 & 6,43 & 10,61 & 13,83 & 0,32 & $-0,09$ & 0,20 & 23,18 & poor & & 0 & 0,3 & 0 & & 013 & 20 & 0,48 \\
\hline $\begin{array}{l}\text { T-2-2-E33 } \\
\text { TT-C2-E34 }\end{array}$ & $\begin{array}{l}0,20 ; 0,10 \\
010.000\end{array}$ & $\begin{array}{l}3,20 ; 3,30 \\
3,30 \cdot 340\end{array}$ & $\begin{array}{r}8,77 \\
22.13\end{array}$ & $\begin{array}{l}0,00 \\
0,00\end{array}$ & $\begin{array}{l}10,06 \\
4468\end{array}$ & 0 & $\begin{array}{l}0,32 \\
468\end{array}$ & 50,65 & 149 & 208 & $\begin{array}{l}-0,82 \\
-37\end{array}$ & 0,20 & $\begin{array}{l}113,42 \\
3415\end{array}$ & poor & & 0 & 040 & 10 & 05 & 13 & 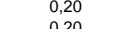 & 0,48 \\
\hline & $\begin{array}{l}0,10,0,00,00 \\
0,0 ; 0-0,10\end{array}$ & $\begin{array}{l}3,3,30 ; \\
3,40 ;\end{array}$ & $\begin{array}{l}22 \\
39\end{array}$ & & $\begin{array}{l}44 \\
47\end{array}$ & & $\begin{array}{l}4,6 \\
4,3\end{array}$ & & $\begin{array}{c}11,49 \\
0,66\end{array}$ & 0.00 & & 020 & $\begin{array}{l}34,15 \\
973\end{array}$ & $\begin{array}{l}\text { poor } \\
\text { close }\end{array}$ & $3600+70$ & -0.05 & $\begin{array}{l}0,42 \\
-3,35\end{array}$ & 0.10 & & 0.13 & $\begin{array}{l}0,20 \\
0,20\end{array}$ & $\begin{array}{l}0,48 \\
0,48\end{array}$ \\
\hline $\begin{array}{l}\mathrm{r}-\mathrm{C}-2-\mathrm{-}-35 \\
\mathrm{Tr}-\mathrm{E}\end{array}$ & $\begin{array}{l}0,0 ; 0,-1,10 \\
-0,10 ; 0,20\end{array}$ & $\begin{array}{l}3,400 ; 3,50 \\
3,50,360\end{array}$ & $\begin{array}{l}3,9,0 f \\
38,82\end{array}$ & $\begin{array}{l}8,61 \\
7,57\end{array}$ & $\begin{array}{l}4 ! \\
51\end{array}$ & $\begin{array}{l}0,00 \\
0,00\end{array}$ & $\begin{array}{l}4,30 \\
0,99\end{array}$ & $\begin{array}{l}0,33 \\
0,66\end{array}$ & $\begin{array}{l}0,66 \\
0,66\end{array}$ & $\begin{array}{l}0,0 \\
0,0\end{array}$ & $\begin{array}{l}3,30 \\
3,34\end{array}$ & $\begin{array}{l}0,20 \\
0,20\end{array}$ & $\begin{array}{l}9, / 3 \\
15,99\end{array}$ & $\begin{array}{l}\text { close } \\
\text { close }\end{array}$ & $3690 \pm 70$ & $\begin{array}{l}-0,05 \\
-0,15\end{array}$ & $\begin{array}{l}-3,35 \\
-3,49\end{array}$ & $\begin{array}{l}0,10 \\
0,10\end{array}$ & 0,0 & $\begin{array}{l}, 1,13 \\
0,13\end{array}$ & $\begin{array}{l}0,20 \\
0,20\end{array}$ & $\begin{array}{l}0,48 \\
0,48\end{array}$ \\
\hline Tr-C2 & $-0,20$ & 3,$60 ; 3,70$ & 33,01 & & & 0 & 1 & & $\begin{array}{l}0,65 \\
0,65\end{array}$ & 0, & 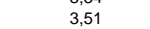 & 0,20 & 13,86 & close & & $-0, \quad 0$ & $-3,7$ & 0 , & 0 & 0, & 20 & 48 \\
\hline Tr-C2-E38 & $-0,30$ & 3,70 & 9 & 34,53 & 46 & 8,14 & 0 & 0 & 0, & 0,00 & 4,30 & 0,20 & 20,27 & poor & $4230 \pm 60$ & $-0,35$ & $-4,6$ & 0, & 0 & 0,13 & 20 & 0,48 \\
\hline Tr-C2-E39 & $\begin{array}{l}-0,40 ; \\
0\end{array}$ & 3,$80 ; 3,90$ & $\begin{array}{l}3,63 \\
11,47\end{array}$ & & 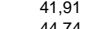 & & 0,3 & & 0,33 & 0,00 & 348 & 0,20 & $\begin{array}{l}21,98 \\
\end{array}$ & poor & & -0, & -4, & & & & 0 & 48 \\
\hline & $\begin{array}{r}-0,50 \\
-0,60\end{array}$ & $\begin{array}{l}3,90 \\
4,00\end{array}$ & & & & & & & & & $\begin{array}{l}3,48 \\
3,433\end{array}$ & 0 & $\begin{array}{l}19,28 \\
13,77\end{array}$ & $\begin{array}{l}\text { poor } \\
\text { close }\end{array}$ & & & $\begin{array}{l}-4, \\
-4\end{array}$ & & & & 20 & 48 \\
\hline Tr-C2-E42 & $\begin{array}{l}-0,00,=, 0,0 \\
-0,70 ; 0,80\end{array}$ & $\begin{array}{l}4,0,0 ; \\
4,10 ;\end{array}$ & $\begin{array}{l}4,, 55 \\
42,04\end{array}$ & 14,33 & $\begin{array}{l}42 \\
45\end{array}$ & $0_{0}$ & $\begin{array}{l}1,5 \\
1,2\end{array}$ & $\begin{array}{l}0,00 \\
0,00\end{array}$ & 0, & 0 & $\begin{array}{l}3,43 \\
3,39\end{array}$ & $\begin{array}{l}0,20 \\
0,20\end{array}$ & $\begin{array}{l}15,24 \\
14,1\end{array}$ & $\begin{array}{l}\text { close } \\
\text { close }\end{array}$ & & $\begin{array}{l}-0,05 \\
-0,75\end{array}$ & $\begin{array}{l}-4,00 \\
-4,14\end{array}$ & 0,10 & $\begin{array}{l}0,05 \\
0,05\end{array}$ & 0,13 & $\begin{array}{l}0,20 \\
0,20\end{array}$ & $\begin{array}{l}0,48 \\
0,48\end{array}$ \\
\hline Tr-C2-E43 & -0 & 4,20; & 0 & & 0 & & 0 & & 0, & 0 & $\ldots$ & $\ldots$ & & liose & & & & & & & & \\
\hline Tr-C2-E44 & -0 & 4,3 & 0 & 0 & 0 & 0,00 & 0 & 0 & 0 & 0,00 & $\ldots$ & $\ldots$ & $\ldots$ & $\ldots$ & & & $\ldots$ & $\ldots$ & . & $\ldots$ &. & 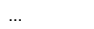 \\
\hline$c_{2}$ & $\begin{array}{r}-1,00 \\
\end{array}$ & 4,4 & & 11,54 & & & 0 , & & 0, & 0 & 4, & 0,20 & 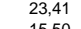 & poo & & & $-5,4$ & 0, & 05 & 0,13 & 20 & 48 \\
\hline $\begin{array}{l}\text { Ir-C2-E46 } \\
\text { r-C.C2-E47 }\end{array}$ & $\begin{array}{l}-1,10 ; 0 ;-1, \\
-120-1\end{array}$ & & & & $\begin{array}{r}55 \\
55\end{array}$ & & & & 0 & & 3, & 0,7 & & $\begin{array}{l}\text { close } \\
\text { close }\end{array}$ & & & -4 & & & & & 望8 \\
\hline Tr-C2-E48 & $\begin{array}{l}-1,20 ;-1,30 \\
-1,30 ; 1,40\end{array}$ & $\begin{array}{l}4,600 ; 4,70 \\
4,70 ; 4,80\end{array}$ & $\begin{array}{l}36,61 \\
26,83\end{array}$ & 12,20 & $\begin{array}{l}50 \\
39\end{array}$ & 0,39 & 0, & $\begin{array}{l}0,0 \\
0,0\end{array}$ & $\begin{array}{l}0,00 \\
0,00\end{array}$ & $\begin{array}{l}0,6 \\
0, c\end{array}$ & $\begin{array}{l}3,500 \\
4,10\end{array}$ & $\begin{array}{l}0,20 \\
0,20\end{array}$ & $\begin{array}{l}8,200 \\
23,14\end{array}$ & $\begin{array}{l}\text { lisse } \\
\text { poor }\end{array}$ & 60 & & $\begin{array}{l}-4,61 \\
-5,45\end{array}$ & 0, & $\begin{array}{l}0,005 \\
0.05\end{array}$ & $\begin{array}{l}0,13 \\
0,13\end{array}$ & $\begin{array}{l}0,20 \\
0.20\end{array}$ & $\begin{array}{l}0,48 \\
0,48\end{array}$ \\
\hline$T_{T-C 2}$ & $-1,40 ;-1,50$ & 4,8 & 0, & 0 & 0 & & 0 & & 0 & 0,00 & & & & pout & & & & 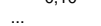 & & & & \\
\hline Tr-C2-E50 & $-1,50 ;$ & 4,90 & 0 & 0 & 0 & 0 & 0 & 0,00 & 0, & 0,00 & & & $\ldots$ & $\ldots$ & & & $\ldots$ & $\ldots$ & $\ldots$ & & & ... \\
\hline col & -1 & & 34,55 & & & & 7,7, & & 2 & 0,41 & & & & close & $50 \pm 70$ & & & & & & & \\
\hline$-\mathrm{C} 2$ & & & & & & & & & & & & & & poor & & & & & & & & 18 \\
\hline Tr-C-253 & $\begin{array}{r}-1,1,000,-1,90 \\
-190\end{array}$ & $\begin{aligned} 5,20,5,3,30 \\
530.540\end{aligned}$ & 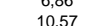 & $\begin{array}{l}24,18 \\
5610\end{array}$ & $\begin{array}{l}40,52 \\
2927\end{array}$ & $\begin{array}{l}2,1,45 \\
081\end{array}$ & $\begin{array}{l}3,98 \\
325\end{array}$ & 0,00 & $\begin{array}{l}0,00 \\
0,00\end{array}$ & 0,000 & 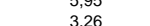 & $\begin{array}{l}x_{0220} \\
0.20\end{array}$ & $\begin{array}{l}38,03 \\
1121\end{array}$ & $\begin{array}{l}\text { coor } \\
\text { close }\end{array}$ & & $\begin{array}{l}-1,85 \\
-195\end{array}$ & $\begin{array}{l}-1,801 \\
-521\end{array}$ & $\begin{array}{l}0,10 \\
010\end{array}$ & 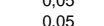 & $\begin{array}{l}0,13 \\
0,13\end{array}$ & 0 & $\begin{array}{l}0.48 \\
0.48\end{array}$ \\
\hline
\end{tabular}


Table S4. Relative total (dead and alive) abundances of foraminifera taxa found within the samples collected from the core A-C14 (Arun saltmarsh, bay of Brest). Sample code $\begin{gathered}\text { Elevation }(\mathrm{m} \\ \text { NGF) }\end{gathered}$
Depth (m)

\begin{tabular}{|c|c|c|c|c|c|c|c|c|c|}
\hline A-C14-E01 & 3,$50 ; 3,40$ & $0.00 ; 0.10$ & 25,67 & 25,33 & 37,67 & 0,33 & 11,00 & 0,00 & 0,00 \\
\hline 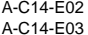 & $\begin{array}{l}3,40 ;, 3,30 \\
3,30 ;, 32\end{array}$ & $\begin{array}{l}0.10 ; 0.20 \\
0.20 .030\end{array}$ & $\begin{array}{l}60,70 \\
54.37\end{array}$ & $\begin{array}{l}4,15 \\
6,15\end{array}$ & $\begin{array}{r}31,31 \\
3948\end{array}$ & 0,00 & $\begin{array}{l}3,83 \\
0,00\end{array}$ & $\begin{array}{l}0,00 \\
0,00\end{array}$ & $\begin{array}{l}0,00 \\
0,00\end{array}$ \\
\hline 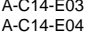 & $\begin{array}{l}3,30 ;, 3,20 \\
3,20 ; 1,0\end{array}$ & $\begin{array}{l}0.20: 0.30 .30 \\
0.30 ; 0.40\end{array}$ & $\begin{array}{l}54,37 \\
43,44\end{array}$ & $\begin{array}{l}6,15 \\
5,83\end{array}$ & $\begin{array}{l}39,48 \\
50,44\end{array}$ & $\begin{array}{l}0,00 \\
0,00\end{array}$ & $\begin{array}{l}0,00 \\
0,29\end{array}$ & $\begin{array}{l}0,00 \\
0,00\end{array}$ & $\begin{array}{l}0,00 \\
0,00\end{array}$ \\
\hline & & & & & & & & & \\
\hline A-C14-E06 & 3,$00 ; 2,90$ & 0.50 & $\begin{array}{l}56,00 \\
56\end{array}$ & $\begin{array}{l}3,00 \\
3.00\end{array}$ & $\begin{array}{l}40,00 \\
40,0\end{array}$ & 0,00 & $\begin{array}{l}1,00 \\
1,00\end{array}$ & 0,00 & $\begin{array}{l}0,00 \\
0,00\end{array}$ \\
\hline A-C14-E07 & 2,$90 ; 2,80$ & $0.60 ; 0.70$ & $\begin{array}{l}60,00 \\
60,00\end{array}$ & 2,00 & 37,00 & 0,00 & 1,00 & 0,00 & 0,00 \\
\hline A-C14-E08 & $\begin{array}{l}2,80 ; 2,70 \\
270\end{array}$ & $0.70 ; 0.80$ & $\begin{array}{l}47,04 \\
3462\end{array}$ & $\begin{array}{l}2,63 \\
1,63\end{array}$ & $\begin{array}{l}49,34 \\
63,78\end{array}$ & 0,00 & 0,99 & 0,00 & $\begin{array}{l}0,00 \\
0\end{array}$ \\
\hline 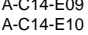 & $\begin{array}{l}2,70 ; 2,2,60 \\
2,60 ; 2,50\end{array}$ & $\begin{array}{l}0.800: 0.90 \\
0.90: 100\end{array}$ & $\begin{array}{r}34,62 \\
30,68\end{array}$ & $\begin{array}{l}\frac{1,60}{0.00} \\
0.00\end{array}$ & $\begin{array}{l}63,78 \\
69,32\end{array}$ & $\begin{array}{l}0,00 \\
0,00\end{array}$ & $\begin{array}{l}0,00 \\
0,00\end{array}$ & $\begin{array}{l}0,00 \\
0,00\end{array}$ & $\begin{array}{l}0,00 \\
0,00\end{array}$ \\
\hline $\begin{array}{l}A-C-C 14-11 \\
A\end{array}$ & $\begin{array}{l}2,0,0,2,2,0,0 \\
2,50: 2,4\end{array}$ & $\begin{array}{l}0.900 .1 .00 \\
1.00: 1.10\end{array}$ & $\begin{array}{l}30,06 \\
37,00\end{array}$ & $\begin{array}{l}0,00 \\
1,00\end{array}$ & $\begin{array}{l}69,32 \\
64,00\end{array}$ & 0,00 & 0.00 & 0,00 & $\begin{array}{l}0,00 \\
0,00\end{array}$ \\
\hline A-C14-E12 & 2,$40 ; 2,30$ & $1.10 ; 1.20$ & 34,00 & $\begin{array}{l}2,00 \\
2,00\end{array}$ & 62,00 & 0,00 & 0,00 & 0,00 & $\begin{array}{l}0,00 \\
0,00\end{array}$ \\
\hline A-C14-E13 & 2,$30 ; 2,20$ & $1.20 ; 1.30$ & 36,43 & 2,75 & 60,82 & 0,00 & 0,00 & 0,00 & 0,00 \\
\hline A-C14-E14 & $\begin{array}{l}2,20 ; 2,10 \\
2,10\end{array}$ & $\begin{array}{l}1.30 ; 1.40 \\
1.40\end{array}$ & 39,68 & 0,00 & 60,32 & 0,00 & 0,00 & 0,00 & $\begin{array}{l}0,00 \\
\end{array}$ \\
\hline $\begin{array}{l}\text { A-C14-14-15 } \\
\text { A-C14-E16 }\end{array}$ & $\begin{array}{l}2,10 ; 2,2,00 \\
2000,1,10\end{array}$ & $\begin{array}{l}1.40 ; 1.50 \\
1.50 \cdot 1.10\end{array}$ & $\begin{array}{l}67,33 \\
39,93\end{array}$ & $\begin{array}{l}0,33 \\
9,24\end{array}$ & $\begin{array}{l}32,34 \\
50,83\end{array}$ & $\begin{array}{l}0,00 \\
0,00\end{array}$ & $\begin{array}{l}0,00 \\
0,00\end{array}$ & 0,00 & $\begin{array}{l}0,00 \\
0\end{array}$ \\
\hline $\begin{array}{l}A-C 1 \\
A-C 14-17\end{array}$ & $\begin{array}{l}2,0,1,1,90 \\
1,90: 1,80\end{array}$ & $\begin{array}{r}.500,1.00 \\
1.60: 1.170\end{array}$ & $\begin{array}{l}39,93 \\
377.71\end{array}$ & $\begin{array}{l}9,24 \\
0,34\end{array}$ & $\begin{array}{l}50,83 \\
61,28\end{array}$ & $\begin{array}{l}0,00 \\
0,67\end{array}$ & $\begin{array}{l}0,00 \\
0,00\end{array}$ & $\begin{array}{l}0,00 \\
0,00\end{array}$ & $\begin{array}{l}0,00 \\
0,00\end{array}$ \\
\hline A-C14-E18 & $\begin{array}{l}1,80 ; 1,70 \\
\end{array}$ & $1.70 ; 1.80$ & 33,55 & 0,66 & 65,45 & 0,00 & 0,33 & 0,00 & $\begin{array}{l}0,00 \\
0,00\end{array}$ \\
\hline A-C14-E19 & 1,$70 ; 1,60$ & $1.80 ; 1.90$ & 46,96 & 0,96 & 47,60 & 0,00 & $\begin{array}{l}4,47 \\
47\end{array}$ & 0,00 & 0,00 \\
\hline & 1,$60 ; 1,50$ & $\begin{array}{l}1.90 ; 2.00 \\
0\end{array}$ & 62,25 & & 28,81 & 0,00 & & 0,00 & 0,00 \\
\hline 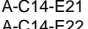 & $\begin{array}{l}1,50 ;, 1,40 \\
1,40.1130\end{array}$ & $\begin{array}{l}2.00 ; 2.10 \\
210.220\end{array}$ & $\begin{array}{l}63,00 \\
6557\end{array}$ & $\begin{array}{l}2,00 \\
2,40\end{array}$ & $\begin{array}{l}25,00 \\
\end{array}$ & 0,00 & $\begin{array}{l}10,00 \\
1208\end{array}$ & 0,00 & $\begin{array}{l}0,00 \\
0\end{array}$ \\
\hline 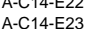 & $\begin{array}{l}-400,1,300 \\
130 \cdot 1,20\end{array}$ & 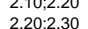 & $\begin{array}{l}\begin{array}{l}65,5 / \\
67.85\end{array} \\
67.5\end{array}$ & $\begin{array}{l}2,40 \\
1,61\end{array}$ & $\begin{array}{r}19,16 \\
29,26\end{array}$ & 0,000 & $\begin{array}{l}72,28 \\
1,29\end{array}$ & $\begin{array}{l}0,00 \\
0,00\end{array}$ & $\begin{array}{l}0,00 \\
0,00\end{array}$ \\
\hline A-C14-E24 & $\begin{array}{l}1,20 ; 1,10 \\
0\end{array}$ & $\begin{array}{l}2.2 .30 ; 2.20 \\
2.20\end{array}$ & $\begin{array}{l}4,52,57 \\
42\end{array}$ & $\begin{array}{l}3,30 \\
3,30\end{array}$ & $\begin{array}{l}5,2,20 \\
52,81\end{array}$ & 0,00 & $\begin{array}{l}1,32 \\
1,32\end{array}$ & 0,00 & $\begin{array}{l}0,00 \\
0,00\end{array}$ \\
\hline A-C14-E25 & 1,$10 ; 1,00$ & $2.40 ; 2.50$ & 46,00 & 5,00 & 48,67 & 0,00 & 0,33 & 0,00 & 0,00 \\
\hline A-C14-E26 & $\begin{array}{ll}1,00 ; 0,90 \\
\end{array}$ & $\begin{array}{l}2.50 ; 2.60 \\
2.00\end{array}$ & 44,73 & 5,43 & 45,05 & 0,00 & $\begin{array}{r}4,79 \\
7,7\end{array}$ & 10 & 0,00 \\
\hline A-C14-E27 & $\begin{array}{l}0,90 ; 0,0,80 \\
0.80 \times 07\end{array}$ & $\begin{array}{l}2.60 ; 2.70 \\
270.27\end{array}$ & $\begin{array}{l}63,14 \\
58,86\end{array}$ & $\begin{array}{l}3,85 \\
2,01\end{array}$ & $\begin{array}{r}26,92 \\
29,43\end{array}$ & 0,32 & & 0,00 & $\begin{array}{l}0,00 \\
0\end{array}$ \\
\hline 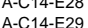 & $\begin{array}{l}0,8 ; 0,0,0,0 \\
0,70 ; 0,60\end{array}$ & $\begin{array}{l}2.100 .2 .80 \\
2.80 ; 2.90\end{array}$ & $\begin{array}{l}58,86 \\
5724\end{array}$ & $\begin{array}{l}2,01 \\
241\end{array}$ & $\begin{array}{r}29,43 \\
38,62\end{array}$ & $0,0,00$ & $\begin{array}{l}9,00 \\
172\end{array}$ & $\begin{array}{l}0,00 \\
0,00\end{array}$ & $\begin{array}{l}0,00 \\
0,00\end{array}$ \\
\hline $\begin{array}{l}A-C 14-E 30 \\
A\end{array}$ & $\begin{array}{l}0,7,0,0,0,0,0 \\
0,60 ;\end{array}$ & $\begin{array}{l}2.00,2, .50 \\
2.90 ; 3.00\end{array}$ & $\begin{array}{l}5,<4 \\
53,80\end{array}$ & $\begin{array}{l}2,41 \\
0,66\end{array}$ & $\begin{array}{l}\text { Sol,or } \\
42,92\end{array}$ & 0,00 & $\begin{array}{l}2,164 \\
264\end{array}$ & 0,000 & $\begin{array}{l}0,00 \\
0,00\end{array}$ \\
\hline 14-E31 & $\begin{array}{l}0,50 ; 0,40 \\
0\end{array}$ & $3.00: 3.10$ & 56,72 & 3,61 & $\begin{array}{l}36,07 \\
36,0\end{array}$ & 0,00 & $\begin{array}{l}3,61 \\
3,61\end{array}$ & 0,00 & $\begin{array}{l}0,00 \\
0,00\end{array}$ \\
\hline -14-Е32 & 0,$40 ; 0,30$ & $3.10 ; 3.20$ & 52,84 & 4,68 & 40,13 & 0,00 & 2,34 & 0,00 & 0,00 \\
\hline 144-E33 & 0,$3 ; 0,0,200$ & $\begin{array}{l}3.20,3.30 \\
3203\end{array}$ & $3^{3}$ & $\begin{array}{l}3,38 \\
3,70\end{array}$ & $\begin{array}{l}28,72 \\
{ }^{28,72}\end{array}$ & $0,0,68$ & $\begin{array}{l}0,00 \\
0,70\end{array}$ & 0,000 & $\begin{array}{l}0,00 \\
0\end{array}$ \\
\hline A-C14-E35 & $\begin{array}{l}0,10 ; 0,00 \\
0\end{array}$ & $3.40 ; 3.50$ & 53,77 & 2,05 & $\begin{array}{l}\begin{array}{r}40,94 \\
36,99\end{array} \\
3\end{array}$ & 0 & 1,37 & $\begin{array}{l}3,00 \\
3,42\end{array}$ & $\begin{array}{l}0,00 \\
2,40\end{array}$ \\
\hline 14-E37 & $\begin{array}{l}0,00 ;-0,10 \\
-010\end{array}$ & $\begin{array}{l}3.50 ; 3.60 \\
360\end{array}$ & 41,58 & $\begin{array}{l}1,67 \\
198\end{array}$ & $\begin{array}{l}47,49 \\
4752\end{array}$ & $\begin{array}{l}0,00 \\
0,00\end{array}$ & $\begin{array}{l}0,67 \\
0.67\end{array}$ & $\begin{array}{l}0,000 \\
0,0\end{array}$ & 0 \\
\hline
\end{tabular}

\begin{tabular}{|c|c|c|}
\hline & & \\
\hline & $\begin{array}{l}0,20 \\
0.20\end{array}$ & $\begin{array}{l}8,60 \\
486\end{array}$ \\
\hline & 0,20 & 13,94 \\
\hline & $\begin{array}{l}0,20 \\
0,20\end{array}$ & $\begin{array}{l}\begin{array}{l}16,08 \\
13\end{array}\end{array}$ \\
\hline 3. & 0,20 & $\begin{array}{l}9,0,47 \\
\end{array}$ \\
\hline & $\begin{array}{l}0,20 \\
0,20\end{array}$ & $\begin{array}{l}9,11 \\
12,37\end{array}$ \\
\hline , o & 0,20 & 20,11 \\
\hline & $\begin{array}{l}0,20 \\
0,20\end{array}$ & $\begin{array}{l}24,20 \\
21,82\end{array}$ \\
\hline 3,79 & $\begin{array}{l}0,20 \\
0,20\end{array}$ & 19,07 \\
\hline & $\begin{array}{l}0,20 \\
0,20\end{array}$ & $\begin{array}{r}18,65 \\
23,33\end{array}$ \\
\hline $\begin{array}{l}3,02 \\
\end{array}$ & 0,20 & 13,92 \\
\hline $\begin{array}{l}3,51 \\
3,80\end{array}$ & $\begin{array}{l}0,20 \\
0,20\end{array}$ & $\begin{array}{l}18,23 \\
22,83\end{array}$ \\
\hline 3,84 & $\begin{array}{l}0,20 \\
0,20\end{array}$ & $\begin{array}{l}2,00 \\
21,02\end{array}$ \\
\hline & $\begin{array}{l}0,20 \\
0,20\end{array}$ & $\begin{array}{l}6,36 \\
3,14\end{array}$ \\
\hline 2,91 & $\begin{array}{l}0,20 \\
0,20\end{array}$ & $\begin{array}{l}1,14 \\
1,90\end{array}$ \\
\hline & $\begin{array}{l}0,20 \\
0,20\end{array}$ & $\begin{array}{l}4,57 \\
9978\end{array}$ \\
\hline & $\begin{array}{l}0,20 \\
0,20\end{array}$ & $\begin{array}{l}9,18 \\
14,02\end{array}$ \\
\hline 3,4 & 0,20 & 15,18 \\
\hline & $\begin{array}{l}0,20 \\
0,20\end{array}$ & $\begin{array}{l}6,18 \\
4,03\end{array}$ \\
\hline & 0,20 & 0,54 \\
\hline 3,19 & $\begin{array}{l}0,20 \\
0.20\end{array}$ & $\begin{array}{l}7,56 \\
7,26\end{array}$ \\
\hline & 0,20 & 4,60 \\
\hline & $\begin{array}{l}0,20 \\
0.20\end{array}$ & $\begin{array}{l}7,61 \\
1405\end{array}$ \\
\hline & 0,20 & 11,04 \\
\hline & & $\begin{array}{l}13,76 \\
12,13\end{array}$ \\
\hline & & \\
\hline
\end{tabular}




\section{Page 67 of 68}

Table S5. Relative total (dead and alive) abundances of foraminifera taxa found within the samples collected from the core A-C10 (Arun saltmarsh, bay of Brest).

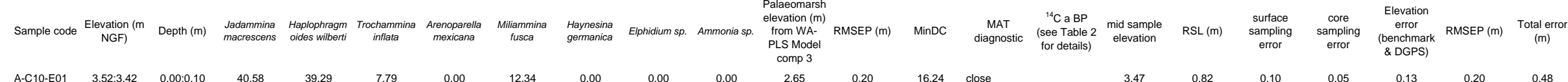

\begin{tabular}{|c|c|c|c|c|c|c|c|c|c|c|c|c|c|c|c|c|}
\hline A-C10-E01 & 3,$52 ; 3,42$ & $0.00 ; 0.10$ & 40,58 & 39,29 & 7,79 & 0,00 & 12,34 & 0,00 & 0,00 & 0,00 & 2,65 & & 0,20 & & 16,24 & close \\
\hline A-C10-E02 & $\begin{array}{l}3,42 ; 3,32 \\
32 ; 0322\end{array}$ & $0.10 ; 0.20$ & 51,16 & 6,31 & 39,87 & 0,00 & 2,66 & 0,00 & 0,00 & 0,00 & 3,24 & & 0,20 & & 8,26 & close \\
\hline $\begin{array}{l}\text { A-CC10-E03 } \\
\text { A-C10-E0 }\end{array}$ & $\begin{array}{l}3,32 ;, 322 \\
3,22 ; 3,12\end{array}$ & $\begin{array}{l}\begin{array}{l}0.20 ; 0.30 \\
0.30 ; 0.40\end{array} \\
0.30\end{array}$ & $\begin{array}{l}66,56 \\
65,15\end{array}$ & $\begin{array}{l}2,68 \\
1,95\end{array}$ & $\begin{array}{l}\begin{array}{l}29,10 \\
32,57\end{array} \\
3\end{array}$ & $\begin{array}{l}0,00 \\
0,00\end{array}$ & $\begin{array}{l}1,67 \\
0,33\end{array}$ & $\begin{array}{l}0,00 \\
0,00\end{array}$ & $\begin{array}{l}0,00 \\
0,00\end{array}$ & $\begin{array}{l}0,00 \\
0,00\end{array}$ & $\begin{array}{l}2,96 \\
3,03\end{array}$ & & $\begin{array}{l}0,20 \\
0,20\end{array}$ & & $\begin{array}{l}8,77 \\
11.37\end{array}$ & $\begin{array}{l}\text { Close } \\
\text { close }\end{array}$ \\
\hline A-C10-EOS & $\begin{array}{l}0 \\
3,12,3,12 \\
3,12,02\end{array}$ & $\begin{array}{l}0.30,0.40 \\
0.40 ; 0.50\end{array}$ & $\begin{array}{l}53,80 \\
5,10\end{array}$ & $\begin{array}{l}1,95 \\
3,63\end{array}$ & $\begin{array}{l}32,57 \\
42.57\end{array}$ & $\begin{array}{l}0,00 \\
0,00\end{array}$ & 0,00 & 0,00 & $\begin{array}{l}0,00 \\
0,00\end{array}$ & $\begin{array}{l}0,00 \\
0,00\end{array}$ & $\begin{array}{l}3,28 \\
3.28\end{array}$ & & & & 10 & \\
\hline A-C 10 -E06 & 3,$02 ; 2,92$ & $0.50 ; 0.60$ & $\begin{array}{l}5,00 \\
56,00\end{array}$ & $\begin{array}{l}3,00 \\
3,00\end{array}$ & 40,00 & $\begin{array}{l}0,00 \\
0,00\end{array}$ & 作 & 0,00 & $\begin{array}{l}0,00 \\
0,00\end{array}$ & 0,00 & 3,22 & & 0.20 & & 9.47 & $\begin{array}{l}\text { close } \\
\text { cose }\end{array}$ \\
\hline A-C10-E07 & 2,$92 ; 2,282$ & $\begin{array}{l}0.60 ; 0.70 \\
0.70\end{array}$ & $\begin{array}{l}60,26 \\
60,26\end{array}$ & 1,60 & 37,50 & 0,00 & 0,64 & 0,00 & 0,00 & 0,000 & 3,15 & & 0,20 & & 10,13 & close \\
\hline $\begin{array}{l}\text { A-C10-E08 } \\
\text {. }\end{array}$ & $\begin{array}{l}2,82 ; 2,72 \\
2720,20\end{array}$ & $\begin{array}{l}0.70 ; 0.80 \\
0.80 .000\end{array}$ & $\begin{array}{l}50,48 \\
52,67\end{array}$ & $\begin{array}{l}2,54 \\
233\end{array}$ & 46,98 & 0,00 & 0,00 & 0,00 & 0,00 & 0,00 & 3,39 & & 0,20 & & 13,84 & close \\
\hline $\begin{array}{l}\text { A-C10-E09 } \\
\text { A-C10-10 }\end{array}$ & $\begin{array}{l}2,72 ; 2,62 \\
2,20,25\end{array}$ & $0.80 ; 0.90$ & 52,67 & $\begin{array}{r}2,33 \\
\end{array}$ & $\begin{array}{l}45,000 \\
{ }^{2}, 03\end{array}$ & 0,00 & $\begin{array}{l}0,00 \\
0\end{array}$ & 0,000 & o, 00 & o, 000 & $\begin{array}{l}3,344 \\
3.2\end{array}$ & & 0,200 & & 年, & close \\
\hline $\begin{array}{l}\text { A-C10-E10 } \\
\text { A-C10-E11 }\end{array}$ & $\begin{array}{l}2,62 ;, 2,52 \\
1,7,2 ; 1,162\end{array}$ & $\begin{array}{l}0.9001 .00 \\
1.80: 1.90\end{array}$ & $\begin{array}{l}47,26 \\
47,03\end{array}$ & $\begin{array}{l}\begin{array}{l}16,44 \\
15,35\end{array}\end{array}$ & $\begin{array}{l}36,30 \\
37,62\end{array}$ & $\begin{array}{l}0,00 \\
0,00\end{array}$ & $\begin{array}{l}0,00 \\
0.00\end{array}$ & $\begin{array}{l}0,00 \\
0,00\end{array}$ & $\begin{array}{l}0,00 \\
0,00\end{array}$ & $\begin{array}{l}0,00 \\
0,00\end{array}$ & $\begin{array}{l}3,18 \\
3,21\end{array}$ & & $\begin{array}{l}0,20 \\
0,20\end{array}$ & & 14,16 & $\begin{array}{l}\text { close } \\
\text { close }\end{array}$ \\
\hline A-C10-E12 & 1,$62 ; 1,52$ & $1.90 ; 2.00$ & 43,24 & 27,70 & 29,05 & 0,00 & 0,00 & 0,00 & $\begin{array}{l}0,00 \\
0,00\end{array}$ & $\begin{array}{l}0,00 \\
0,00\end{array}$ & $\begin{array}{l}3,05 \\
3,1\end{array}$ & & 0.20 & & $\begin{array}{l}14,73 \\
17,73\end{array}$ & $\begin{array}{l}\text { close } \\
\text { close }\end{array}$ \\
\hline A-C10-E13 & 1,$52 ; 1,42$ & $2.00 ; 2.10$ & 61,00 & 8,00 & 22,00 & 0,00 & 9,00 & 0,00 & 0,00 & 0,00 & 2,85 & & 0,20 & & 4,34 & close \\
\hline A-C10-E14 & $\begin{array}{l}1,42 ; 1,32 \\
1320,122\end{array}$ & $\begin{array}{l}2.10 ; 2.20 \\
220.230\end{array}$ & & $\begin{array}{r}12,00 \\
0\end{array}$ & $\begin{array}{l}18,00 \\
2500\end{array}$ & & 00 & & n & 0,00 & 2,10 & & 0,20 & & 6,95 & close \\
\hline A-C10-E15 & $\begin{array}{l}1,32 ; 1,22 \\
1202,1102\end{array}$ & $\begin{array}{l}2.20 ; 2.30 \\
2.20\end{array}$ & 66,00 & 9,00 & 25,00 & 0,00 & 0,00 & 0,00 & 0,00 & 0,00 & 2,87 & & 0,20 & & (5,82 & ose \\
\hline $\begin{array}{l}\text { A-C10-10-16 } \\
\text { A-C10-17 }\end{array}$ & $\begin{array}{l}1,222,1,12 \\
1,1 ; 2,102\end{array}$ & $\begin{array}{l}\begin{array}{l}2.300 .2 .40 \\
2.40: 250\end{array} \\
2.40 .25\end{array}$ & $\begin{array}{l}40,00 \\
47.48\end{array}$ & $\begin{array}{l}\begin{array}{l}31,00 \\
15,97\end{array}\end{array}$ & $\begin{array}{l}47,00 \\
36,55\end{array}$ & $\begin{array}{l}0,00 \\
0,00\end{array}$ & $\begin{array}{l}0,00 \\
0.00\end{array}$ & 0,00 & $\begin{array}{l}0,00 \\
0,00\end{array}$ & $\begin{array}{l}0,00 \\
000\end{array}$ & $\begin{array}{l}3,43 \\
3,18\end{array}$ & & 0,20 & & 18,41 & $\begin{array}{l}\text { ose } \\
\text { soe }\end{array}$ \\
\hline A-C10-E18 & $\begin{array}{l}1,02 ; 0,92 \\
1,1\end{array}$ & $\begin{array}{l}2.40,2.50 \\
2.50 ; 2.60\end{array}$ & $\begin{array}{l}4,4,48 \\
45,00\end{array}$ & 10,00 & 41,00 & $\begin{array}{l}0,00 \\
0,00\end{array}$ & $\begin{array}{l}0,00 \\
4,00\end{array}$ & 0,00 & 0,00 & $\begin{array}{l}0,00 \\
0,00\end{array}$ & 3,30 & & 0,20 & & 7.99 & $\begin{array}{l}\text { close } \\
\text { close }\end{array}$ \\
\hline A-C10-E19 & 0,$92 ; 0,82$ & $2.60 ; 2.70$ & 62,00 & 6,00 & 25,00 & 0,00 & 7,00 & 0,00 & 0,00 & 0,00 & 2,90 & & 0,20 & & 4,51 & close \\
\hline -E20 & 0,$82 ; 0,72$ & $2.70 ; 2.80$ & 57,69 & 10,77 & 31,54 & 0,00 & & 0,00 & 0,00 & 0,00 & 3,04 & & 0,20 & & 13,65 & close \\
\hline A-C10-E21 & $\begin{array}{l}0,72 ; 0,62 \\
0.020,52\end{array}$ & $\begin{array}{l}2.80 ; 2.90 \\
2.20 .300\end{array}$ & 62,96 & 7,78 & 29,26 & 0,00 & 0,00 & 0,00 & 0,00 & 0,00 & 2,97 & & 0,20 & & 15,61 & close \\
\hline $0-E 22$ & $\begin{array}{l}0,62 ; 0,052 \\
0,170.07 \\
0.07\end{array}$ & $\begin{array}{l}2.900 .3 .00 \\
3.353 .35\end{array}$ & $\begin{array}{l}0,00 \\
0,00\end{array}$ & $\begin{array}{l}0,00 \\
0,00\end{array}$ & $\begin{array}{l}0,00 \\
0,00\end{array}$ & 0,0 & $0,0,00$ & 0,00 & $0,0,0$ & 0 & & & & $\ldots$ & & \\
\hline E24 & 0,$12 ; 0,02$ & $\begin{array}{l}3.050 ; 3.50 \\
3.40\end{array}$ & 0,00 & 0,00 & 0,00 & 0,0 & 0,00 & 0,00 & & 0,00 & & & & & & \\
\hline & & & & & & & & & & & & & & & & \\
\hline
\end{tabular}


Table S6. Relative total (dead and alive) abundances of foraminifera taxa found within the samples collected from the core G-C2 (Tresseny saltmarsh).

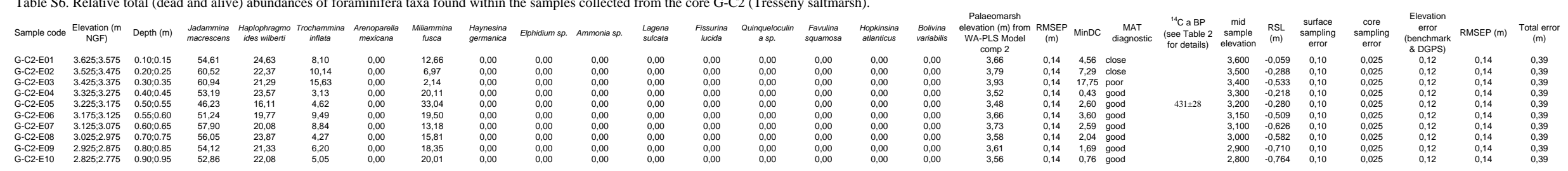

